


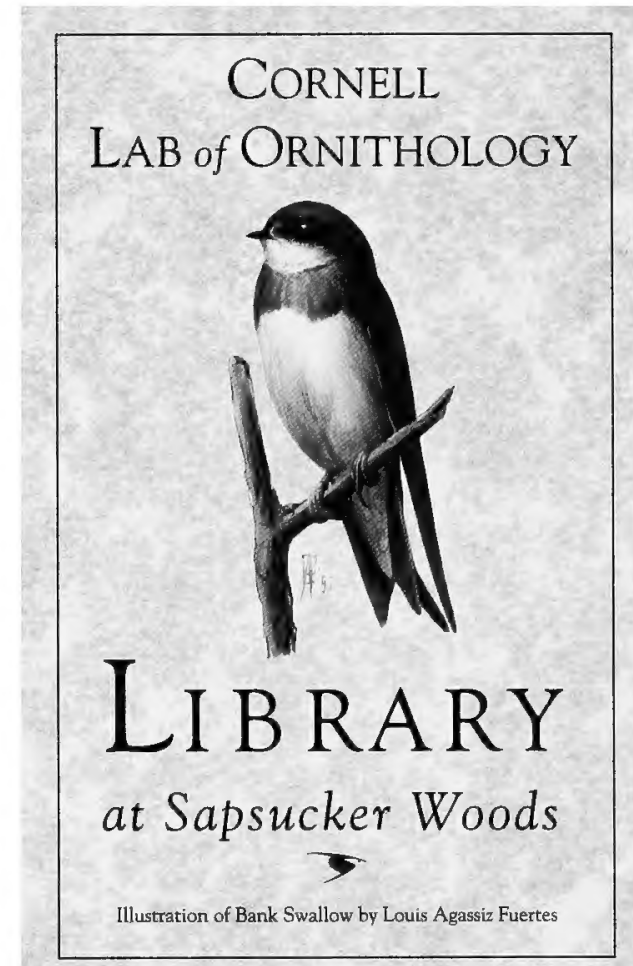




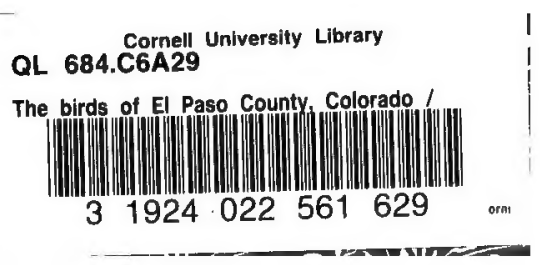

DATE DUE

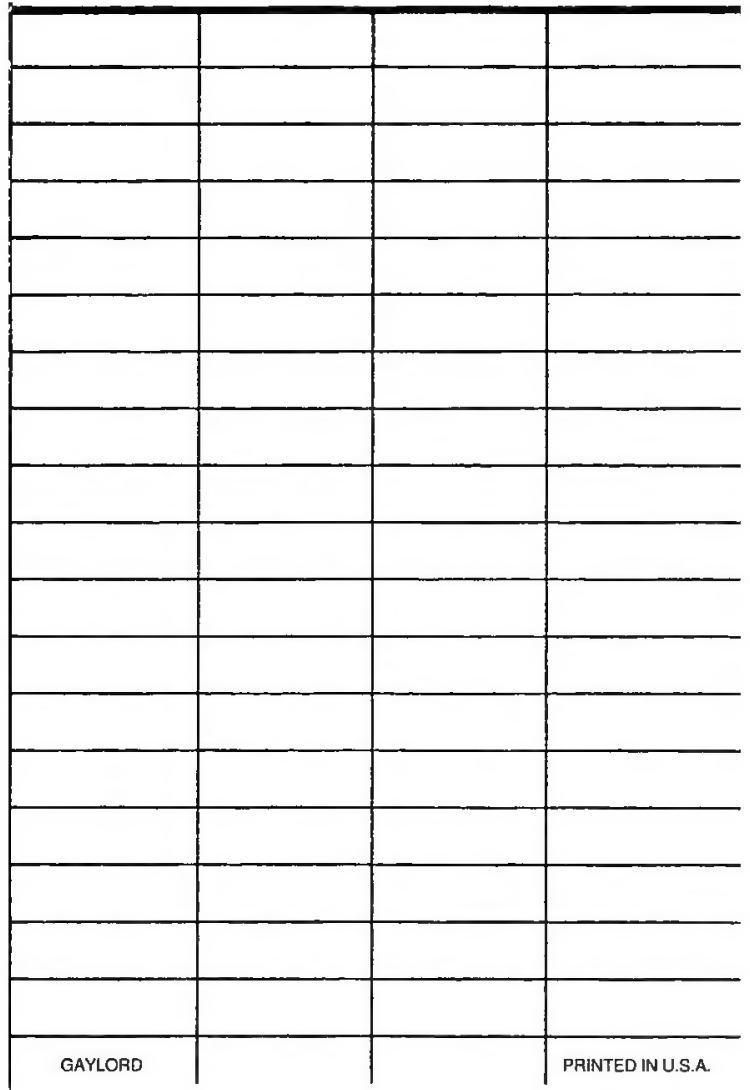




\section{Cornell University Library}

The original of this book is in the Cornell University Library.

There are no known copyright restrictions in the United States on the use of the text.

http://www.archive.org/details/cu31924022561629 




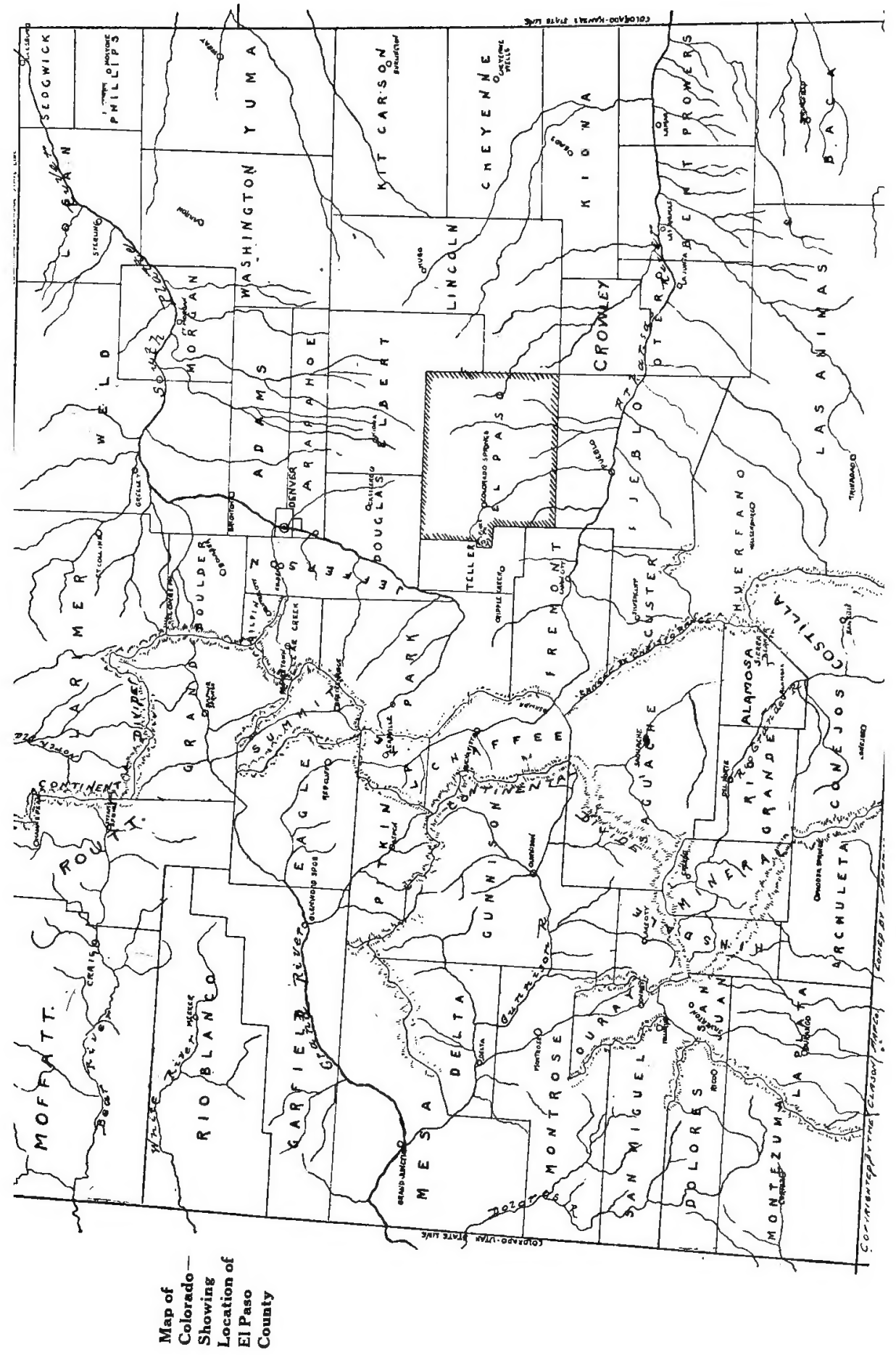



Lororado college Publication.

General Sories No. 74

Science Senies $v / 2$, no $13,1 / 1-2$

$$
\text { p 453 }=496,497-603 \text {. }
$$

May, Jun: - Sept 1914.

\title{
The Birds of
}

El Paso County Colorado

\author{
By \\ CHARLES E. H. AIKEN \\ and \\ EDWARD R. WARREN \\ Director of the Museum, Colorado College \\ PART I \\ Laboratory of Ornithology \\ 159 Sapsucker Woods Road \\ Cornell University \\ Ithaca, New York I4850
}


Ornth

QL

684

C 6

A 29 


\title{
THE BIRDS OF EL PASO COUNTY, COLORADO
}

\author{
AREA INCLUDED IN THIS LIST.
}

The area covered by this list is the whole of El Paso County, while various notes are given for points without the boundaries of the County, but adjacent thereto, especially that portion of the Pikes Peak Region in which are situated the Seven Lakes.

\section{TOPOGRAPHY.}

More than two-thirds of El Paso County is a rolling prairie country, most of the eastern portion of which is dry, with few or no permanent streams, though there are watercourses in which water is found at times, and various springs. The exceptions to this statement are Fountain and Monument Creeks, the former heading in the mountains above Ute Pass, and the latter on the Divide at Palmer Lake and in the foothills west of there, and emptying into the Fountain at Colorado Springs. These streams flow in a somewhat southeasterly course along the east base of the foothills. As shown on the map, the Fountain also receives other tributaries from the west, which have their sources in the mountains.

The extreme western portion of the County is mountainous, occupied by the Pikes Peak Range, which culminates in the well known Pikes Peak, once the objective point of the gold seekers of 1859, now that of the tourists of the twentieth century, who may reach its summit, over 14,000 feet above sea level, by rail. Part of this range is in El Paso County, and part in Teller County, and the boundary lines between the two counties were so drawn that it is difficult to write of that portion of our area without, at times, including a part of Teller County.

This mountain region is rugged, and includes besides Pikes Peak, a number of summits ranging from 11,000 to 
above 12,000 feet elevation, and its eastern portion is cut by cañons, many of which are renowned for their beauty or grandeur, such as the Ute Pass, Williams Cañon, Bear Creek Cañon, and North and South Cheyenne Cañons. Ute Pass is the outlet through the mountains by which the Fountain, once called La Fontaine Qui Bouille by the old French trappers, reaches the plains. The trappers called the stream by this name because of the bubbling mineral springs where Manitou is now, and the pass was so named because it was the highway by which the Ute Indians reached the plains. Streams are found in all these various cañons, and high in the mountains about Pike's Peak are Lake Moraine and the Seven Lakes, converted into reservoirs which belong to the water supply system of Colorado Springs.

Standing somewhat apart from the rest, at the southeasterly end of the range, is Cheyenne Mountain, rising abruptly from the plains, and though not lofty, but little over 9,000 feet, it is one of the most beautiful mountains we have, many consider it the most beautiful.

Once the mountains were entirely covered with forest, of pine, spruce, and aspen, but forest fires, some of them many years ago, and some of them of quite recent date, have destroyed considerable of this.

The extreme southwestern portion of the County is a somewhat rolling region, with yellow pines, cedars, and piñons.

The northerly edge of the County is occupied by the "Divide" region, the watershed between the Arkansas and Platte Rivers. This has at Palmer Lake an elevation of 7,200 feet, and the summit of the watershed has an easterly trend. It has an undulating surface, and where not cleared is largely covered by a forest of yellow pines.

About five miles north of Colorado Springs are what are known as the Bluffs, a range of low sandstone ridges presenting sufficient vertical faces which, though low, enough to justify the name. These extend easterly from the foothills for about eight miles out into the plains. They have a few 
yellow pines and cedars growing on them, and considerable scrub oak and other shrubbery, and are good resorts for birds.

The westerly part of the County forms part of the Pike National Forest.

\section{LIFE ZONES.}

Owing to its varied topography we have within the boundaries of El Paso County no less than five life zones, as follows:

Upper Sonoran, Transition, Canadian, Hudsonian, and Arctic-Alpine; the first named comprising the plains region and the very lowest foothills; the Transition the foothills and the lower portions of the mountains, and the other three are wholly mountain zones. Each of these zones is more or less well characterized by the presence of certain plants and animals which are either peculiar to or largely confined to it.

\section{UPPER SONORAN ZONE.}

This zone, which is agriculturally the most important in the County, as noted above covers the plains region. The elevation of its upper boundary varies from a little over $6,00 \mathrm{C}$ to nearly 7,000 feet, depending on the steepness and exposures of the slopes in the foohills, the limit naturally being higher on slopes having a southern exposure than on those with a northern. The piñons and cedars, which are usually considered as belonging to this zone, range even higher at times, but such occasions are really overlappings into the Transition. There are comparatively few of these trees in the County.

In E1 Paso County the following mammals are confined to this zone:

Bailey's Wood Rat, Neotoma f. baileyi, Pale Grasshopper Mouse, Onychonys l. pallescens, Yellow Pocket Gopher. Geonys lutescens, Kangaroo Rat, Perodipus m. richardsoni, Baird's and Plains Pocket Mice, Perognathus flavus and $P$ flavescens, Black-tailed Jack Rabbit, Lepus c. melanotis, Bailey's Cottontail, Sylvilagus a. bailcyi, and possibly a few others. 
The following birds are practically restricted to the zone in the breeding season:

Woodhouse's Jay, Bullock's Oriole, Cañon Towhee, Western Blue Grosbeak, Lazuli Bunting, Long-tailed Chat, Western Mockingbird, Catbird, Brown Thrasher, Baird's Wren, and Western Gnatcatcher. The following species breed especially in the cedar and piñon trees: Ash-throated Flycatcher, Piñon Jay, Black-throated Gray Warbler, Gray Titmouse, and Leadcolored Bush-Tit.

The following trees and shrubs are characteristic of the Upper Sonoran Zone:

Piñon Pine, Pinus edulis, two species of cedar, Juniperus scopulorum and $J$, monosperma, Broad-leaved Cottonwood, Populus occidentalis, Peach-leaf or Almond-leaf Willow, Salix anygdaloides, Gray Saltbush or Bushy Atriplex, A. canescens, Western Clematis, C. ligusticifolia, Flowering Currant, Ribes iongifolium, Wild Plum, Prunus anericana, while six species of scrub oaks are found in this and the lower part of the Transition Zone.

\section{TRANSITION ZONE.}

The Transition Zone covers the greater portion of the foothills and the lower parts of the mountains proper, and the Divide region in the northern portion of the County. The former are naturally more or less rough, and the latter is an undulating country. The upper limit of the Transition in El Paso County varies from 8,000 to 9,000 feet, changing with the slope exposures. The cedars and piñons seemingly overlap into this zone from the zone below, and there are some places where it is difficult to decide to which zone that locality belongs.

In this County there is but one mammal which can ve said to be restricted to. this zone, the Northern Tuft-eared or Plain-backed Squirrel, Sciurus aberti ferreus, though the Plains or Coues's Pocket Gopher, Thomomy's clusius, Estes 
Park Cliff Mouse, Peromy'scus nasutus, and Gale's Wood Rat, Neotoma $m$. falla $x$, are quite characteristic of it. Other species range into it from the zones above and below.

The following birds are quite characteristic of this zone in the breeding season:

Sharp-shinned Hawk, White-throated Swift, Wright's Flycatcher, Long-crested Jay, Mountain Towhee, Green-tailed lowhee, Plumbeous Vireo, MacGillivray's IVarbler, Rocky Mountain Nuthatch, Pgymy Nuthatch, Chestnut-backed Bluebird.

The following trees and shrubs are characteristic of this zone:

Yellow Pine, P. scopulorum, Red or Douglas's Fir, Pseudotsuga mucronata, Willow, S. irrorata, Rocky Mountain Birch, Betula fontinalis, Alder, Alnus tenuifolia. Beaked Hazel-nut, Coryllus rostrata, one species of Gooseberry, Ribes ipptanthum, two species of Ninebark, Physocarpus intermedius and $P$. monygnus, Meadow Sweet, Holodiscus dumosa and $H$. uustralis, and Rocky Mountain Maple, Acer glabrum.

\section{CANADIAN ZONE.}

The Canadian and the two following zones are strictly mountain regions, this one covering the ground from the upper limits of the Transition to between 10,000 and 11,000 feet, and is the most extensive in area of the three Boreal zones. It may be characterized as normally a well forested zone, though none of the trees are exclusively confined to it.

In E1 Paso County no species of mammal appears to be confined to the Canadian Zone, though there are a number common to it and the Hudsonian, to say nothing of others which are also found in the Transition. The following mammals are characteristic of the two lower Boreal zones:

Fremont's Squirrel, S. fremonti, Woodchuck, Marmota sp., Colorado or Rocky Mountain Red-backed Mouse, Ez'otomys g. galei, Colorado or Mountain Pocket Gopher, Thomo- 
mys fossor, Western Red Fox, Vulpes macrourus, Shrew., Sorex $v$. dobsoni, S. personatus, and S. obscurus, and Water Shrew, Neosorex navigator.

The following birds have their center of abundance in the breeding season in the Canadian Zone:

Dusky Grouse, Alpine Three-toed Woodpecker, Rednaped Sapsucker, Williamson's Sapsucker, Olive-sided Flycatcher, Cassin's Finch, Crossbill, Gray-headed Junco, Audubon's Warbler, Red-breasted Nuthatch, Ruby-crowned Kinglet, Townsend's Solitaire, and Audubon's Hermit Thrush.

Though found also in the Hudsonian the heaviest portions of the forests of Limber or Rocky Mountain White Pine, Pinus flexilis, and Engelmann's Spruce, Picea engelmanni, are in the Canadian Zone. The Aspen, Populus tremuloides, has its center of abundance in the Canadian and ranges but little above it. The following willows are common to it and the Hudsonian: Nuttall's or Black Willow, S. nuttalli, Bog Willow, S. glaucops, and Green-leaved Willow, S. chlorophylla.

\section{HUDSONIAN ZONE.}

This is the zone immediately below timberline, above the Canadian; it is intermediate in character between that and the Arctic-Alpine Zone, not having any very strongly marked characters of its own, but in its lower limits having much in common with the Canadian, and in the upper portions sharing some of the characteristics of the Arctic-Alpine. Its upper limit varies in altitude from 11,500 to 12,500 feet.

As stated above under the Canadian Zone, a number of species of mammals are common to these two zones, or rather characteristic of the two together. Of these the IVoodchuck is more abundant toward timberline, and ranges into the zone above, and two additional species, the Cony, Ochotona saxatilis, and Mountain Sheep, are more especially characteristic of this and the zone above, the former being found, in the Pike's Peak Region, mostly from à little below timberline up to the summits of the mountains. 


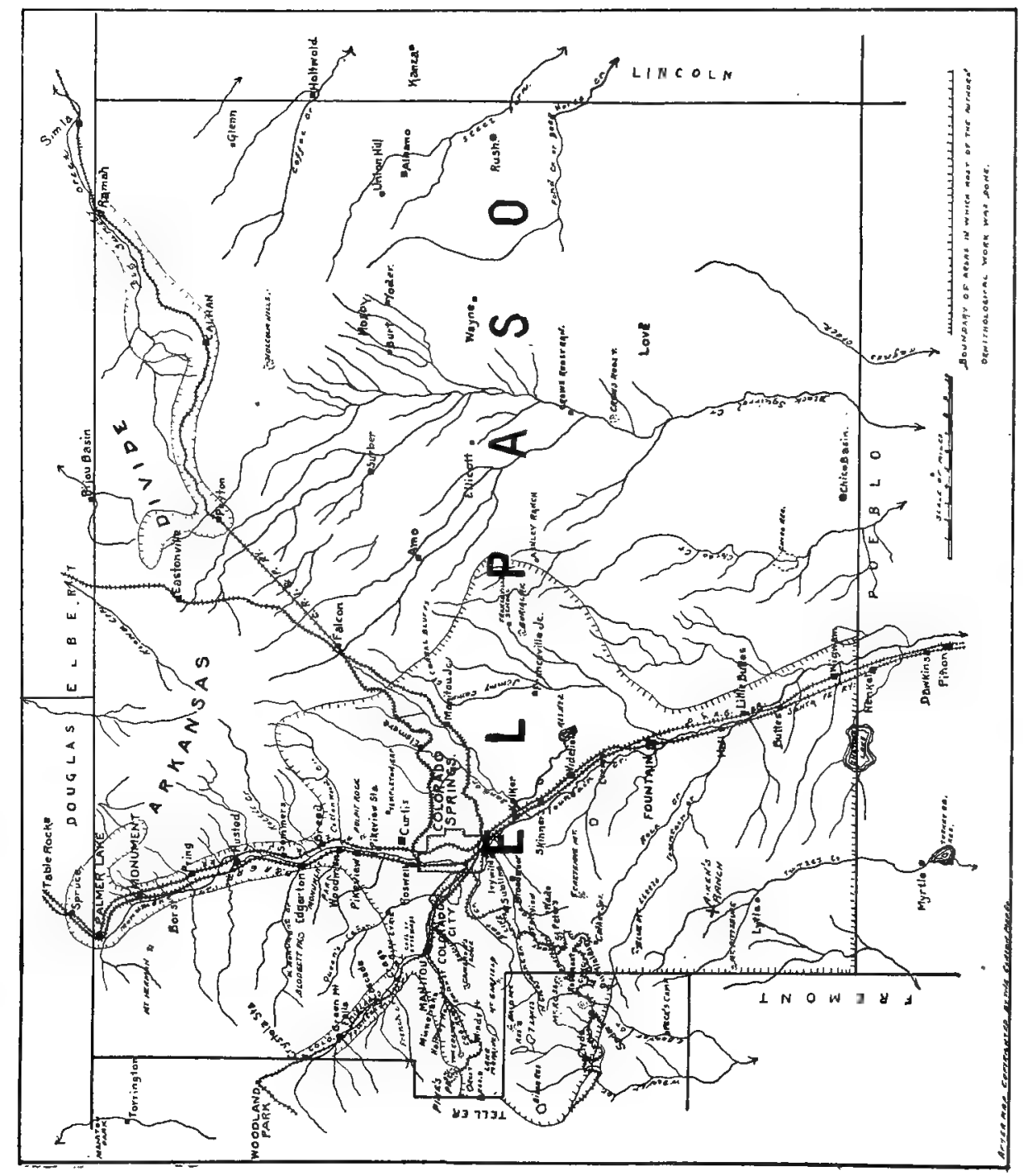

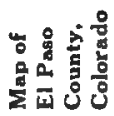



Plate I.

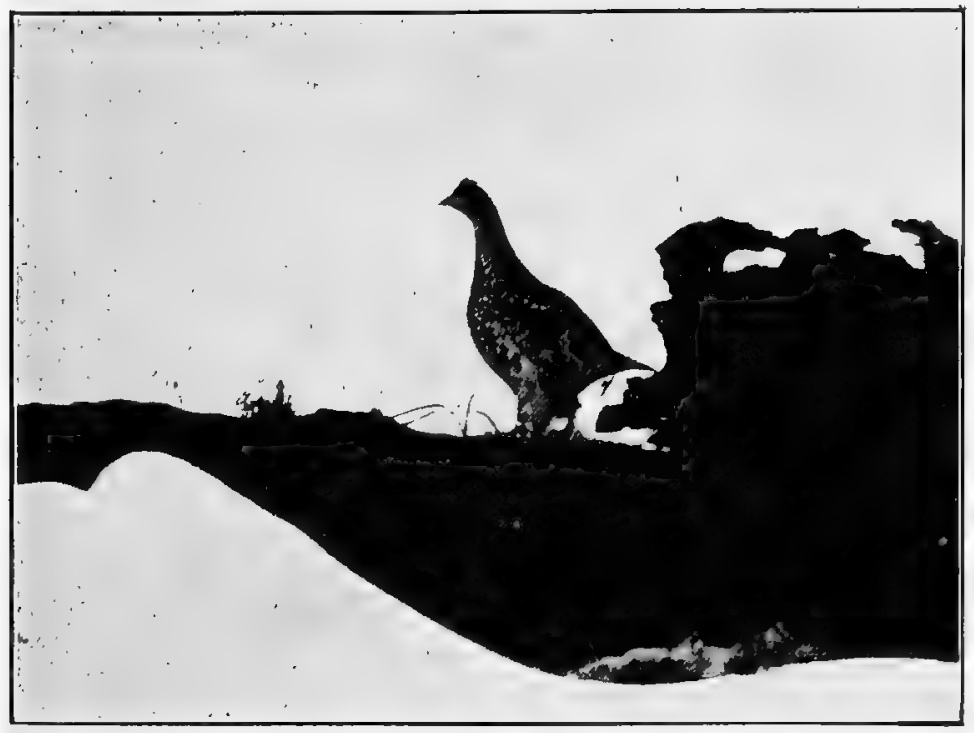

Fig. $T$.

E. R. Warren, Photo.

Dusky Grouse.

Gunnison County, Colo.

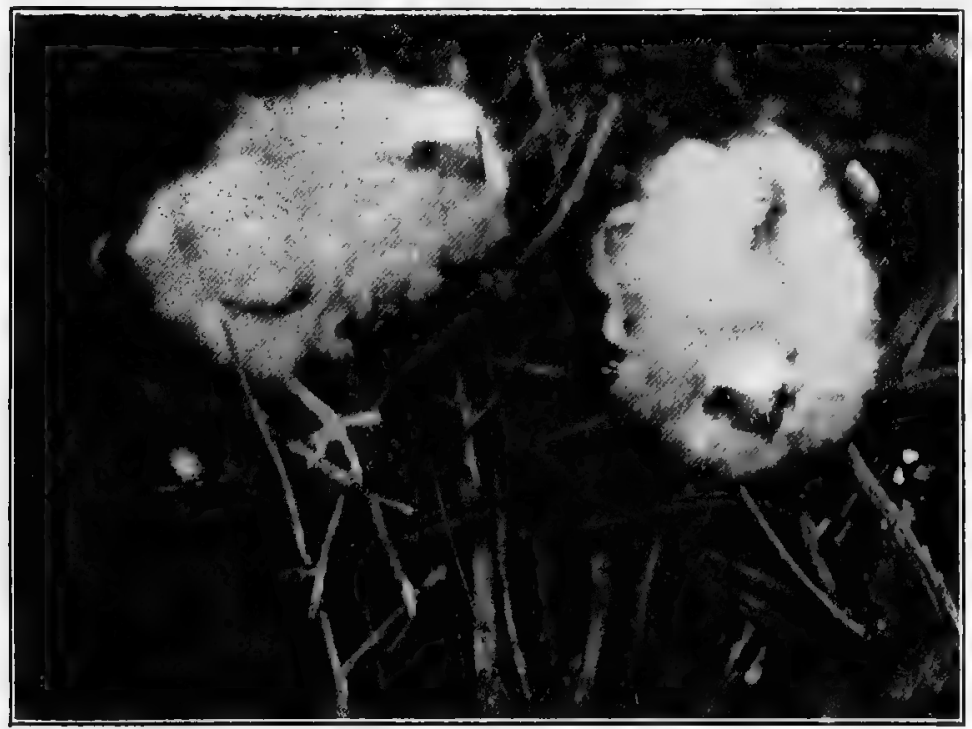

Fig. 2.

L. L. Shaw, Photo,

Young Sharp-Shinned Hawks, a Frw Days Old, Crystal Park, Colo, 
Plate II.

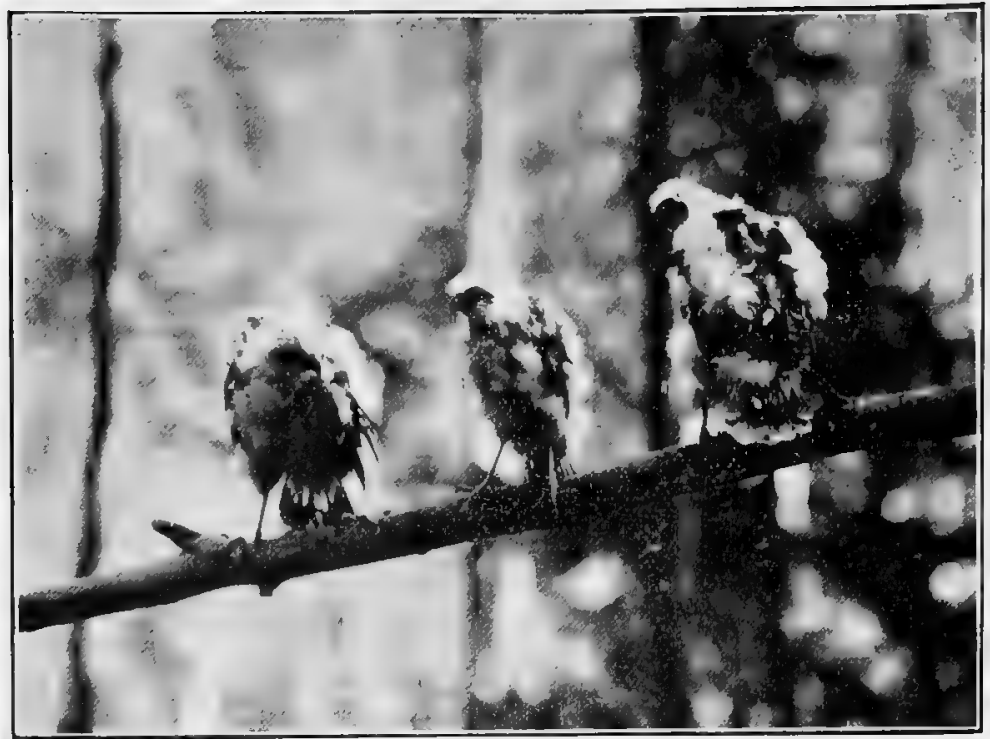

Fig. 3.

E. R. W.. Photo.

Young Sharp-Shinned Hawks, About Three Weeks Old.

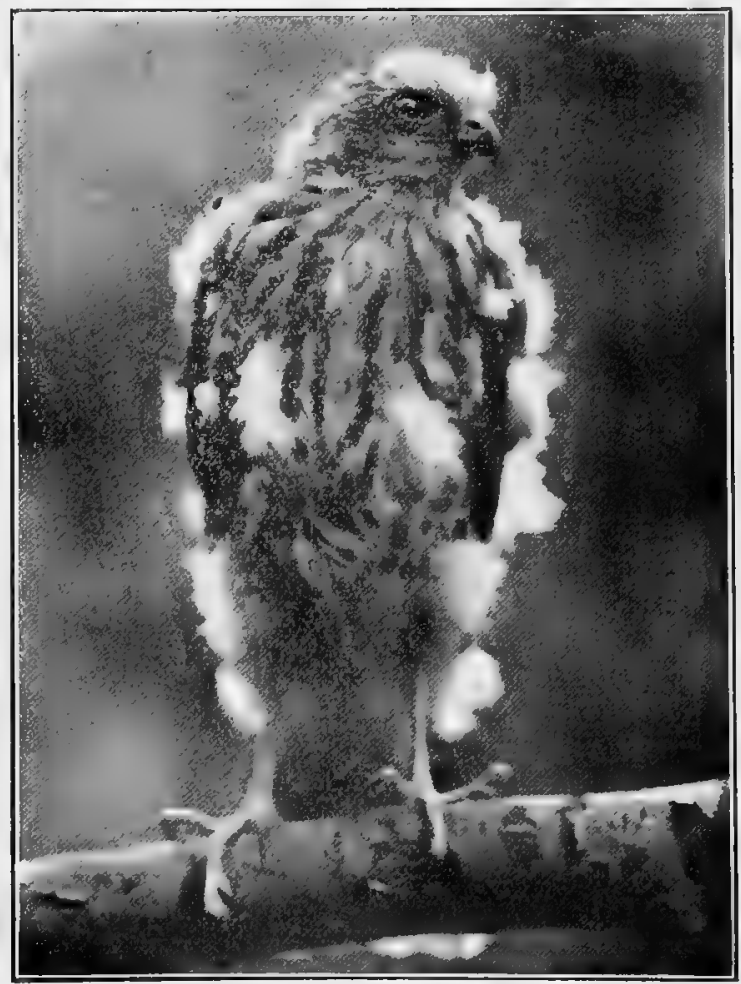

Fig. 4.

Young Sharp-Shinned Hawks, About Four Weeks Old. Crystal Park. 
Of birds, the Rocky Mountain Jay, Rocky Mountain Pine Grosbeak, and Rocky Mountain Creeper probably breed principaily within the limits of the Hudsonian, though there are a number of other breeders in common with other zones.

'The only tree which seems to be confined to the Hudsonian is the Foxtail Pine, Pinus aristata, which grows from 10,250 $f$ r et up to timberline. This zone also includes the upper portivin: of the Engelman's Sprice and White Pine forests, and in it arc also found the willows n!enlioned under the Canadian as common to both.

\section{ARCTIC-ALPINE ZONE.}

The Arctic-Alpine Zone is the region above timberline, characterized by slopes devoid of trees and with but four species of woody plants growing thereon, though a number of flowering plants are characteristic of it, or nearly so.

No species of mammals is restricted to this zone, but it shares a number of species with the zone below, some of which live here the year round, and others, like the Mountain Sheep, Fox, Coyote, and Black Bear, range into it from below. Some of the species living in this zone the year round are the Woodchuck, Cony, Rocky Mountain Field Mouse, and Colorado Pocket Gopher.

One species of bird is restricted to this zone in the breeding season, the Brown-capped Rosy Finch, and the Pipit is practically so, and the Desert Horned Lark also breeds in the bare spaces, while the White-crowned Sparrow and Pileolated Warbler breed in the willow thickets for five hundred feet above timberline. The Sparrow has been known elsewhere in the State to raise a brood at a lower elevation early in the season, and then to move above timberline and raise a second family, but we have no information as to whether it does this here. A few other birds range intermittently above timberline.

But four species of woody plants grow above timberline, the Dwarf Willow, Saliz saximontana, and another willow, $S$. 
brachycarpa, which are found from 9,000 up to 14,000 feet, Shrubby Cinquefoil, Dasiphora fruticosa, 6,500 to 12,400 feet, and the White Mountain Avens, Dryas octopetala, 11,500 to 14,000 feet.

The following plants are characteristic of this zone: Catchfly or Campion, Silene acaulis, three species of Saxifrage, Sarifraga debilis, austronontana, and rhomboidea, Stonecrop, Sedum integrifolium, Alpine Mertensia, Mertcnsia alpina. Forgetmenot, Myosotis alpestris, Lousewort, Pedicularis parrvi, Polemonium, Polemonium confertum, Knotweed, Polygonum viviparum, Gentian, Swertia palustris, Mountain Avens, Sieversia turbinata, Phlox, Phlox condensata, Figwort, Synthyris alpina, Clover, Trifolium nanum, Colorado Candytuft, Thlaspi coloradense.

\section{CLIMATE.}

In general the climate of $\mathrm{El}$ Paso County may be described as temperate, usually without great extremes of heat or cold. though the thermometer does on rare occasions in summer go above ninety in the shade, and similarly in winter fall to thirty below zero. But usually the temperatures are moderate, and neither of the extremes are so hard to bear as in many other places. The plains region has the higher temperature in summer, while there is no great difference in the minimum winter temperatures over the whole county, though the daily mean temperature is greater on the plains than in the mountains.

The rainfall is greatest in the mountains, and least on the plains toward the eastern edge of the County. The winter snowfall is light, comparatively so in the mountains, where it is probably not more than half that on the Continental Divide and the other ranges to the west of us. The snowstorm early in December, 1913, when about two feet of snow fell in Colorado Springs and much more in the mountains, was a very exceptional storm, the like of which had not been known for more than thirty years, and as a rule the deepest snowfalls are in spring, when the snow does not last long. 
The number of hours of sunshine are unusually great, a day when the sun does not shine at all being extremely rare. The heavy rain and hail storms which occasionally occur during the breeding season are sometimes destructive to nesting birds, their eggs and young, and a late cold storm in the spring sometimes does much harm to migrants and late arrivals of - summer birds. In winter an unusually heavy snowfall may prevent seed-eating birds from obtaining food for a short time, but the snow rarely lays on the ground more than a few days.

As a whole the climate of the County may be described as favorable to bird life.

\section{WORKERS IN THE REGION.}

The first ornithologist to visit El Paso County was Dr. J. A. Allen, who came here with an expedition sent out by the Museum of Comparative Zoology, Harvard College, early in August, 1871, and collected along the east base of the foothills from Palmer Lake to Colorado City. His report was published in July, 1872, the first list of Colorado birds.

C. E. Aiken, the senior author of the present paper, came to Colorado Springs, October 26, 1871, not long after the founding of the town, and thenceforward spent much time in collecting in the vicinity, his work for the first two years being nearly all done at his ranch on Turkey Creek, fifteen niles southwesterly from Colorado Springs. The first results of his work were edited by Dr. T. M. Brewer and published in the Proceedings of the Boston Society of Natural History, December, 1872.

H. D. Minot of Boston spent some time in the County in the summer of 1879 , and the results of his observations were published in the Bulletin of the Nuttall Ornithological Club.

In March, April, and May, 1882, Dr. J. A. Allen and William Brewster were in Colorado Springs, and did much collecting in the vicinity, publishing their list in 1883, Bulletin of the Nuttall Ornithological Club. Bendire's Thrasher and 
the Florida Gallinule were added to the list of Colorado Birds by these distinguished ornithologists.

W. C. Ferrill and Horace G. Smith did a certain amount of collecting in the County while doing work for the State Historical and Natural History Society, making some additions to our list.

E. R. Warren, the junior author of this paper, came to Colorado Springs the fall of 1881 , but did no bird work until the next winter, and then did considerable collecting during the winters of 1882-83 and 1883-84. This was dropped for several years, partly owing to absence from the city, and not taken up again here until some dozen or so years ago, since which time he has been making observations and collecting somewhat steadily.

William Lutley Sclater came to Colorado Springs in the autumn of 1906 to take the position of Director of the Museum of Colorado College, retaining this office mintil the spring of 1909, and spending most of the College year in Colorado Sirrings, but his summers at his home in England. Though Mr. Sclater did but little field work while here, it was through lis influence that the Aiken Collection of Birds was purchased for Colorado College, and it was during his residence here that "The History of the Birds of Colorado" was written, a work which, though by one who had been in the state but comparatively little, shows a great comprehension of the arifauna of Colorado, and represents a great amount of labor on his part in not only going over all the specimens at his command, but also in looking up all the records and literature bearing on the subject. Colorado bird students owe $\mathrm{Mr}$. sclater a debt of gratitude for the excellent work he has done.

A number of others have made brief stavs in the region and published popular articles or books on our birds, while there are some local observers, who, while taking much interest in observing our birds, have published little or nothing about them. 


\section{SURVEY OF BIRD LIFE.}

The bird life of El Paso County is of a very varied character, nearly all the groups of birds found in the State being represented, while the number of species is a goodly one, 276 all told. The fact that within our limits all the life zones of the State are represented has naturally much to do with this.

That the various species of water birds are not specially abundant is due to the lack of suitable localities to attract them, and any incease in the number of artificial reservoirs along the base of the mountains or on the plains will surely be followed by an increase in the number of waterfowl coming to the region and stopping for a short time at least.

Among the grouse we note the absence of the Ptarmigan, of whose occurrence in the County there is no authentic record. This is due to the fact that the Pike's Peak Range is an isolated one, not connected with the other high ranges of the State, or rather not by any mountains sufficiently high to afford a continuous habitat for this Alpine bird, and moreover the area in the Pike's Peak Range which would be attractive to it is very limited, so that it is not strange it has not gained a foothold here.

Two of our Gallinaceous birds have been exterminated within the last forty years, the Sharp-tailed Grouse and Wild T'urkey.

Birds of prey are well represented, both in species and indivirtuals, and the type locality of one subspecies, Aiken's Screech Owl, is within the limits of the County. The Woodpeckers have a good number of species. The Poor-will and Nighthawk and one or more Hummingbirds are commor. Flycatchers of various species are numerous, the Magpie and several jays are noticeable, and the Icteridce are represented by blackbirds, the Meadowlark, and Bullock's Oriole.

Sparrows of course show many species, a tanager is common, about all the swallows of temperate North America are here, and a couple of vireos. The list of Warblers is fairly 
long, we have the Pipit, Water Ousel, and several of the Mimida, wrens, nuthatches, several of the Parida, two kinglets, a gnatcatcher, Solitaire, several thrushes, Robin, and three bluebirds.

This brief résumé shows what a field for bird study the County affords. It has given several original records to the Colorado list, and a considerable number of the rarer species have been reported from here.

\section{ANALYSIS OF THE BIRD FAUNA.}

We have divided the birds of the County into the eight following categories, the first six of which are identical with those of Sclater in his History of the Birds of Colorado.

$A$-Resident throughout the year.

$B$-Summer residents, migrating south in winter.

C-Birds which breed within the County, and occasionally winter, though usually going further south.

$D$-Birds not known to breed within the County, but found more or less commonly in winter.

E-Birds not known to breed within the County, but more or less regular transients through in spring and autumn.

F-Birds not known to breed in the County, which have been taken or seen on from one to half a dozen occasions.

$G$-Species which formerly occurred in the County but now exterminated or not seen for many years.

$H$-Introduced species.

It is not always easy to determine in which category some of the species should be placed, but we believe the following lists are as near correct as they can be made with the information at hand.

$A$-Resident throughout the year, 46 species. Virginia Rail, Scaled Quail, Dusky Grouse, Ferruginous Roughleg, Golden Eagle, Long-eared Owl, Aiken's Screech Ow1, Western Horned Owl, Acadian Owl, Rocky Mountain Pygmy Owl, 
Road Runner, Rocky Mountain Hairy Woodpecker, Batchelder's Woodpecker, Alpine Three-toed Woodpecker, Red-shafted Flicker, Desert Horned Lark, Magpie, Long-crested Jay, Woodhouse's Jay, Rocky Mountain Jay, Raven, Clarke's Nutcracker, Piñon Jay, Western Evening Grosbeak, Rocky Mountáin Pine Grosbeak, Cassin's Finch, Crossbill, Mexican Crossbill, Brown-capped Rosy Finch, Goldfinch, Pale Goldfinch, Pine Siskin, Gray-headed Junco, Mountain Song Sparrow, Cañon Towhee, Water Ousel, Cañon Wren, Rocky Mountain Creeper, Rocky Mountain Nuthatch, Red-Breasted Nuthatch, Pygmy Nuthatch, Gray Titmouse, Long-tailed Chickadee, Mountain Chickadee, Lead-colored Bush-Tit, Townsend's Solitaire.

$B$-Summer residents, migrating south in winter, 84 species. Sora, Killdeer, Mountain Plover, Western Mourning Dove, Turkey Vulture, Sharp-shinned Hawk, Cooper's Hawk, Krider's Hawk, Western Redtail, Swainson's Hawk, Prairie Falcon, Duck Hawk, Sparrow Hawk, Burrowing Owl, Belted Kingfisher, Red-naped Sapsucker, Williamson's Sapsucker, Red-headed Woodpecker, Poor-will, Western Nighthawk, White-throated Swift, Broad-tailed Hummingbird, Rufous Hummingbird, Kingbird, Arkansas Kingbird, Cassin's Kingbird, Ash-throated Flycatcher, Say's Phoebe, Olive-sided Flycatcher, Western Wood Peewee, Western Flycatcher, Traill's I'lycatcher, Least Flycatcher, Hammond's Flycatcher, Wright's Flycatcher, Cowbird, Yellow-headed Blackbird, Thick-billed Kedwing, Bullock's Oriole, Brewer's Blackbird, Bronzed Grackle, Arkansas Goldfinch, Arizona Goldfinch, Mexicarı Goldfinch, Western Vesper Sparrow, Western Savannah Sparrow, Western Lark Sparrow, White-crowned Sparrow, Western Chipping Sparrow, Brewer's Sparrow, Lincoln's Sparrow, Green-tailed Towhee, Black-headed Grosbeak, Western Blue Grosbeak, Lazuli Bunting, Lark Bunting, Western Tanager, Cliff Swallow, Barn Swallow, Tree Swallow, Violet-green Swallow, Rough-winged Swallow, White-rumped Shrike, Western Warbling Vireo, Plumbeous Vireo, Virginia's Warbler, Orange-crowned Warbler, Yellow Warbler, Audu- 
bon's Warbler, Black-throated Gray Warbler, MacGillivray's Warbler, Western Yellow-throat, Long-tailed Chat, Pileolated Warbler, Redstart, Pipit, Mockingbird, Catbird, Brown Thrasher, Rock Wren, Western House Wren, Ruby-crowned Kinglet, Audubon's Hermit Thrush, Chestnut-backed Bluebird.

C-Birds which breed within the County, and occasionally winter, though usually going further south, 7 species. Spotted Sandpiper, Marsh Hawk, Lewis's Woodpecker, Western Meadowlark, Mountain Towhee, Western Robin, Mountain Bluebird.

$D$-Birds not known to breed within the County, but found more or less commonly in winter, 28 species. Wilson's Snipe, Goshawk, Western Goshawk, Rough-legged Hawk, Bald Eagle, Pigeon Hawk, Richardson's Pigeon Hawk, Shortcared Owl, Rocky Mountain Screech Owl, Gray-crowned Rosy Finch, Hepburn's Rosy Finch, Black Rosy Finch, Redpoll, Alaska Longspur, Chestnut-collared Longspur, McCown's Longspur, Western Tree Sparrow, White-winged Junco, Slatecolored Junco, Intermediate Junco, Shufeldt's Junco, Montana Junco, Pink-sided Junco, Arctic Towhee, Bohemian Waxwing, Northern Shrike, Prairie Marsh Wren, Western Goldencrowned Kinglet.

$E$-Birds not known to breed within the County, but more or less regular transients passing through in spring and autumn, 52 species. Eared Grebe, Pied-billed Grebe, Loon, Rlack-throated Loon, Ring-billed Gull, Forster's Tern, Black Tern, White Pelican, Merganser, Mallard, Gadwall, Baldpate, Green-winged Teal, Blue-winged Teal, Cinnamon Teal, Spoonbill, Pintail, Redhead, Canvas-back, Lesser Scaup, Golden-eye, Buffle-head, Ruddy Duck, Bittern, Great Blue Heron, Snowy Egret, Black-crowned Night Heron, Little Brown Crane, Coot, Northern Phalarope, Wilson's Phalarope, Longbilled Dowitcher, Baird's Sandpiper, Least Sandpiper, Semipalmated Sandpiper, Greater Yellow-legs, Yellow-legs, Western Solitary Sandpiper, Western Willet, Long-billed Curlew, Black-bellied Plover, Baird's Sparrow, Western Grasshopper 
Plate III.

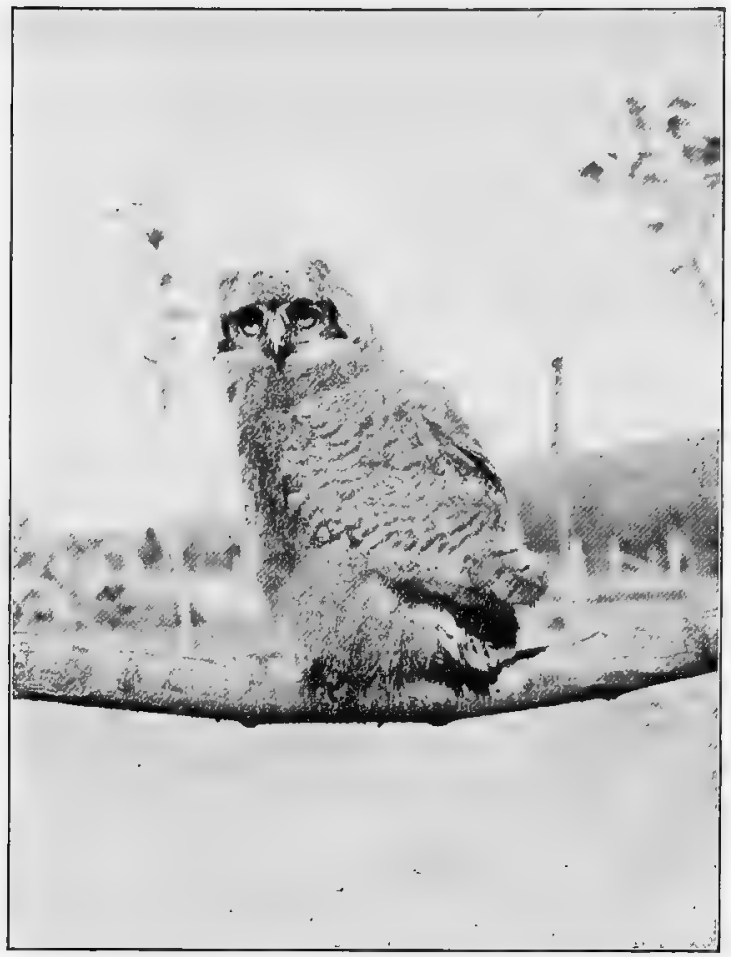

Fig. 5.

E. R. W., Photo.

Yot'ng Western Horned OwL. Delta County, Colo.

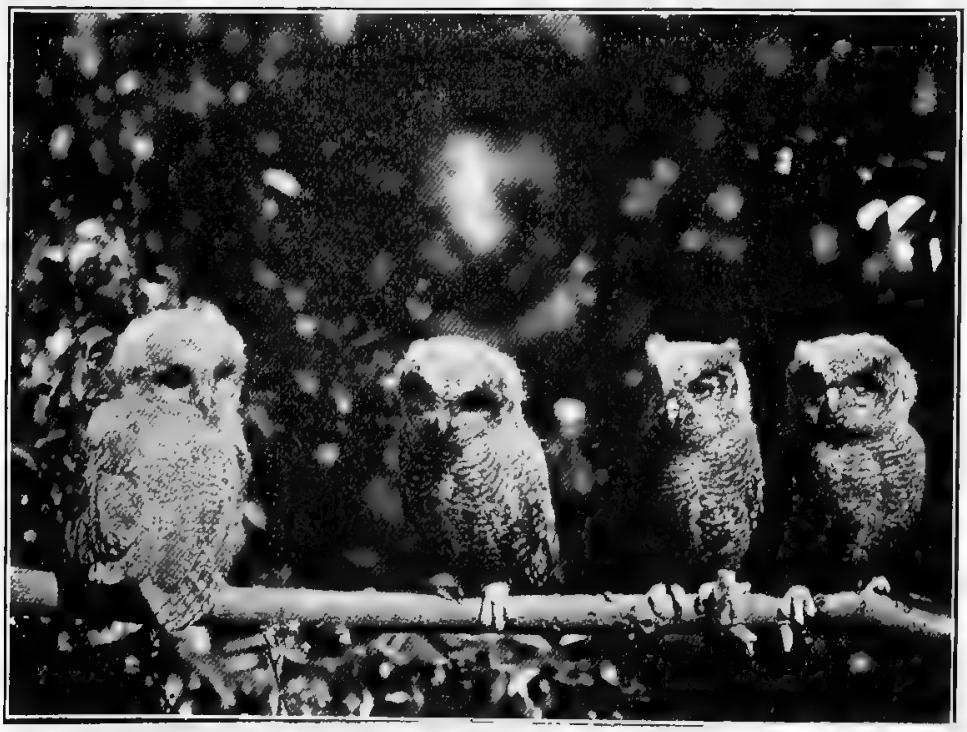

Fig. 6.

IE. R. W., Photo.

Yolng Airen's Screech OWLS. Colorado Springs. 
Plate IV.

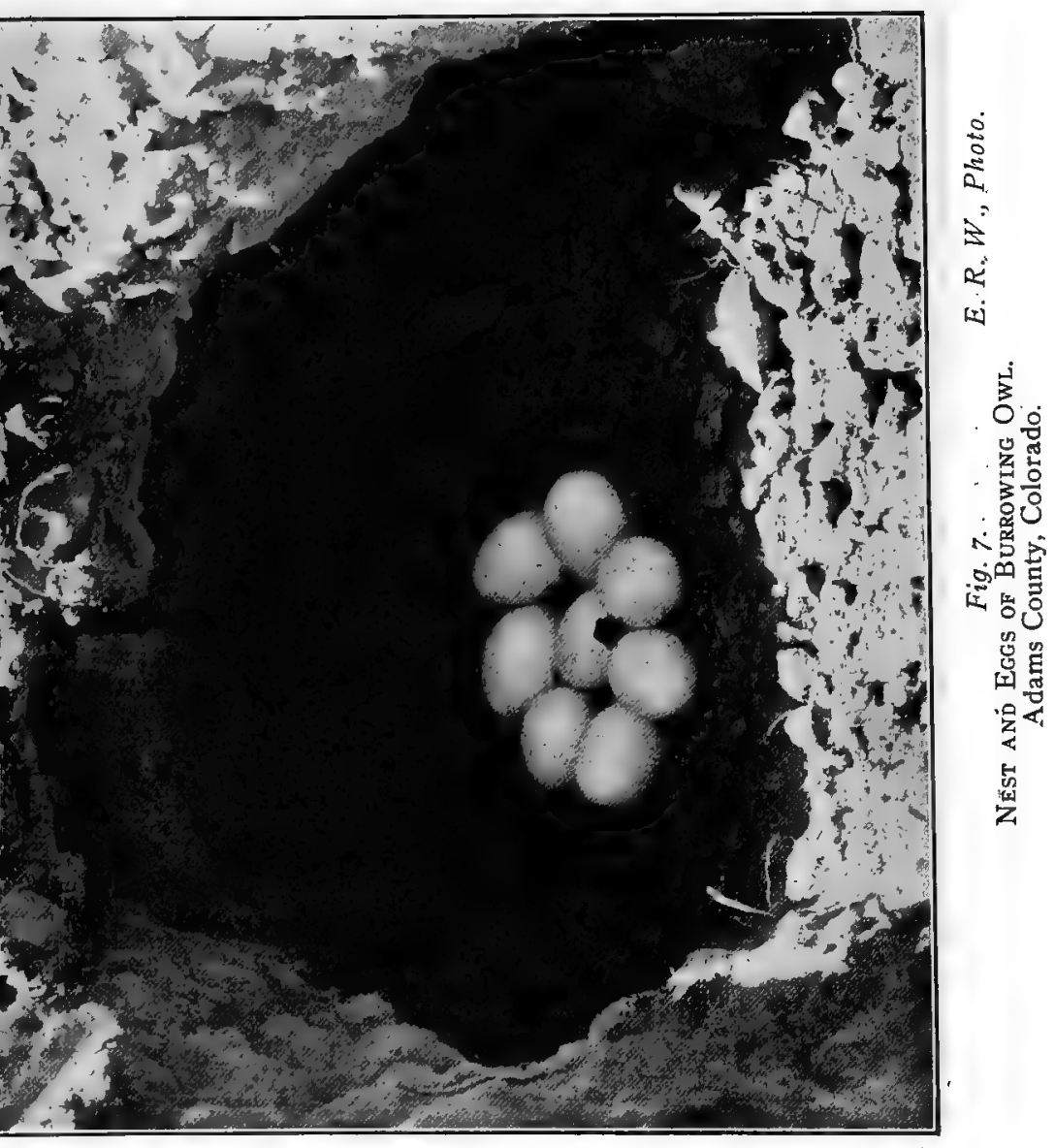


Sparrow, Gambel's Sparrow, Clay-colored Sparrow, Cassin's Vireo, Tennessee Warbler, Myrtle Warbler, Black-poll Warbler, Willow Thrush, Olive-backed Thrush, Alaska Hermit Thrush.

F-Birds not known to breed in the County, which have been taken or seen on from one to half a dozen occasions, 51 species. Bonaparte's Gull, Double-crested Cormorant, Hooded Merganser, Ring-necked Duck, White-winged Scoter, Snow Goose, Greater Snow Goose, Canada Goose, Hutchins's Goose, Whistling Swan, Least Bittern, Egret, Reddish Egret, Sandhill Crane, Florida Gahinule. Stilt Sandpiper, Whiterumped Sandpiper, Upland Plover, Golden Plover, Band-tailed Figeon, Swallow-tailed Kite, Mississippi Kite, Osprey, Spotted Owl, Flammulated Owl, Arctic Horned Owl, Black-billed Cuckoo, Red-bellied Woodpecker, Black-chinned Hummingbird, Calliope Hummingbird, Gray Flycatcher, Blue Jay, Crow, Bobolink, Rusty Blackbird, Snow Bunting, Harris's Sparrow, Dakota Song Sparrow, Swamp Sparrow, Indigo Bunting, Dickcissel, Scarlet Tanager, Bank Swallow, Cedar Waxwing, Prothonotary Warbler, Northern Parula Warbler, Oven-bird, Sage Thrasher, Baird's Wren, Western Gnatcatcher, Bluebird.

$G$-Species formerly occurring in the County, but now exterminated or not seen for many years, 3 species. Columbian Sharp-tailed Grouse, Merriam's Turkey, White-necked Raven.

$H$-Introduced species, 4. Bob-white, California Quail. Ring-necked Pheasant, House Sparrow.

\section{ACKNOWLEDGMENTS.}

We wish to acknowledge help or notes from the following:

The Bureau of the Biological Survey, U. S. Department of Agriculture, through its Chief, Mr. H. W. Henshaw, and Assistant Ornithologist, Mr. H. C. Oberholser, has identified various specimens for us, mention of which is usually specifically made in the text.

Mr. William Brewster has kindly examined his notes made 
in 1882, looking up certain points for us. Mr. Alex. Wetmore sent a manuscript list of the birds observed by himself and R. B. Rockwell at Palmer Lake, September 5 and 6, 1909, with permission to make any use we desired of it. Dr. Edward C. Schneider of Colorado Coollege was good enough to read over the account of the life zones and give suggestions as to the characteristic plants, while much information was gathered from his "Distribution of Woody Plants in the Pike's Peak Region." Mr. Lloyd L. Shaw has permitted the use of manuscript notes made about Colorado Springs and in Crystal Park as well as the photographs of the young Sharp-shinned Hawks. Mr. Clark Mellen of New York has kindly given information as to the introduction of game birds at Glen Eyrie.

The cuts of the Long-eared Owl, Horned Owl, Burrowing Owl's Nest, Three-toed Woodpeckers, Nighthawk on the ground, the two of the young Magpies and the Magpie's nest, and the two cuts of Cliff Swallow's nests, were loaned by the "Condor," published by the Cooper Ornithological Club of California.

\section{EXPLANATION.}

The nomenclature of the American Ornithologists' Union has been strictly adhered to in this list, except in the case of the Juncos, where it was departed from for reasons there stated.

It should be stated that Monument Valley Park, frequently mentioned herein, refers to the park of that name in the city of Colorado Springs, and not to Monument Park, some six miles north of the city, and the location of the Woodmen's Sanatorium.

Whenever the Aiken Collection is mentioned, the collection of birds purchased from C. E. Aiken by General William J. Palmer and presented to Colorado College is referred to. It comprises the results of Aiken's collecting from his arrival in 1871 until 1907.

\section{BIBLIOGRAPHY.}

Aiken, C. E., and C. N. Holden, JR. Notes on the Birds of 
Wyoming and Colorado Territories. Proc. Boston Soc. Nat. Hist., XV., 1872, pp. 193-210. This was edited by Dr. T. M. Brewer, and only the notes signed "C. E. A.," contributed by Aiken, refer to Colorado. They are the results of the field work of his first winter and spring in Colorado (1871-72), and which was practically all done at his ranch on Turkey Creek, southwest of Colorado Springs. 59 species are credited to the State, in addition to those hitherto known to occur here.

Aiken, C. E. A Glimpse at Colorado and its Birds. Amer. Nat., VII, 1873, p. 13. Notes on birds seen on an October day on Beaver Creek.

Aiken, C. E. A New Species of Sparrow. Amer. Nat., VII, 1873, pp. 236-7. Centronyx ochrocephalus described from type taken on plains 14 miles east of Fountain, about October 5, 1872. This proved to be identical with Centronyx (now Ammodramus) bairdi, and was practically a rediscovery of that species.

Arren, C. E. The Nidification of the Blue Crow [Piñon Jay] and the Gray-headed Snowbird. Amer. Sport. V. 1875, p. 370 . The first account of the nests and eggs of these two species.

Aiken, C. E. Seven New Birds for Colorado. Auk, XVII, 1900, p. 298. Adds as new to the state fauna Gavia arctica, from Colorado Springs; Ardea egretta, 5 miles south of Colorado Springs; Syrnium nebulosum, Holyoke; Astragulinus tristis pallidus, Colorado Springs; Geothlypis agilis, Lake, Lincoln Co.; Geothlypis trichas, Colorado Springs (this specimen is now referred to $G$. $t$. occidentalis) ; Wilsonia canadensis, Lake, Lincoln Co.

Allen, J. A. Notes of an Ornithological Reconnaisance of portions of Kansas, Colorado, Wyoming and Utah. V. List of Birds observed at the Eastern Base of the Rocky Mountains in Colorado Territory, between Colorado City and Denver, in July and August, 1871; with Annotations. Bull. Mus. Comp. Zool., III, 1872, pp. 113-183. A very 
important paper for Colorado Ornithology, and the first list pertaining to our region as there are many notes about Palmer Lake and Colorado City.

Allen, J. A. Ornithological Notes from the West. II. Notes on the Birds of Colorado. Amer. Nat., VI, pp. 342-351.

Allen, J. A., And W. Brewster. List of Birds observed in the Vicinity of Colorado Springs, Colorado, during March, April, and May, 1882. Bull. Nutt. Orn. Club, VIII, 1883, pp. 51-161, and 189-198. A very important paper for our region. Bendire's Thrasher and Florida Gallinule first recorded for Colorado.

Arnold, W. W. Bird Enemies of the Chinese Cotton Scale. Auk, XXIX, 1912, p. 113. Redpolls and Pine Siskins observed to eat the cottony scale on maple trees in Colorado Springs. T. D. A. Cockerell on page 400 of the same volume corrects the name of the insect, and states that it is Pulvinaria innumerabilis, and that it is a species native to America.

BaIley, F. M. Handbook of the Birds of the Western United States, including the Great Plains, Great Basin, Pacific Slope, and Lower Rio Grande Valley. Boston and New York. First edition 1902. Several others published since. Descriptions of the species, distribution, etc. $12 \mathrm{mo}$.

Brewster, W. Recent Occurrence of the Flammulated Owl in Colorado. Bull. Nutt. Orn. Club, VIII, 1883, p. 123. Letter from C. E. Aiken in regard to the occurrence of this speciès near Colorado Springs.

Chapman, F. M. The Warblers of North America. New York, 1907. 8vo. Certain El Paso County references.

Cooke, W. W. Ten New Birds from Colorado. Auk, XI, 1894, pp. 182-3. Ardetta exilis first recorded for Colorado from specimen taken near Colorado Springs.

Cooke, W. W. The Birds of Colorado. Bull. No. 37, State Agricultural Collège, Fort Collins, Cólo., 1897, pp. 1-144. 
Further Notes on the Birds of Colorado. Bull. No. 4, 1898, pp. 145-176.

The Birds of Colorado. Second Appendix to Bulletin No. 37. Bull. No. 56, 1900, pp. 177-239. The most complete list of Colorado birds up to time of publication, and containing many El Paso County records.

Cooke, W. W. A New Bird for Colorado. Oregon Naturalist, IV, 1897-8, p. 165. Stellula calliope taken at Colorado Springs.

Felger, A. H. The Prothonotary Warbler in Colorado. Auk, XXIV, 1907, p. 342 ; also Condor, IX, 1907, p. 110. Reports capture of three specimens by B. G. Voight, one of which was taken between Palmer Lake and Monument.

Henseiaw, H. W. Report upon Ornithological Specimens collected in the Years 1871, 1872 and 1873, in Geographical and Geological Explorations and Surveys West of the One Hundredth Meridian. First Lieutenant George M. Wheeler, Corps of Engineers, in charge. Washington, 1874. Pp. 133-507, pls. I-XV. Some El Paso County notes by Aiken and Henshaw.

Keyser, L. S. Birds of the Rockies. Chicago, 1902. 8vo. A popular work and containing some El Paso County notes.

Miller, O. T. A Bird Lover in the West. Boston and New York, 1894. 16mo. Popular book; contains observations made near Colorado Springs.

Minot, H. D. Notes on Colorado Birds. Bull. Nutt. Orn. Club, V, 1880, pp. 181-2, and 223-232. Contains notes made near Manitou and Seven Lakes.

Oberholser, H. C. The North American Forms of Astragalinus psaltria (Sag). Proc. Biol. Soc. Wash., XVI, pp. 113-116, September 30, 1903. Reviews status of $A$. $p$. psaltria, A. p. arizonce, and $A$. p. mexicanus, concludes variations in color are due to age, and cites a series of specimens taken at Colorado Springs in the breeding season and containing all three forms. 
Pike, Z. M. An Account of Expedition to the Sources of the Mississippi, and through the Western Parts of Louisiana to the Sources of the Arkansaw, Kans., La Platte and Pierre Juan Rivers, performed by the order of the Government of the United States during the years 1805, 1806, and 1807, etc., etc. Philadelphia, 1810, 8vo. The portion relating to the attempted ascent of Pike's Peak has allusion to the Pheasant, i. e., Dusky Grouse.

Ridgway, R. On Some New Forms of North American Birds. Amer. Nat. VII, 1873, pp. 603-615.

Contains description of Junco hyemalis aikeni from type taken by Aiken in El Paso County.

Ridgway, R. On Buteo harlani (Aud.) and B. cooperi (Cass.), Auk, II, 1885, p. 165.

Note on a specimen from El Paso County in the Aiken Collection. (This specimen did not come from El Paso County, nor is the locality from which it did cnme known. It is not now in the collection.)

Ridgway, R. The Birds of North and Middle America. (Bull. U. S. Nat. Mus., No. 50.) Parts 1, 1901 ; 2, 1902; 3, $1904 ; 4,1907 ; 5,1911$. (Incomplete.)

SClater, W. L. Winter Birds of Colorado. Kbis, 1908, pp. 443-450. Notes on birds about Colorado Springs.

Sclater, W. L. A History of the Birds of Colorado. London, 1912. With 17 plates and a map. Sq. demy 8vo.

The only work on Colorado birds giving descriptions, habits, with references to all records and literature. Many E1 Paso County notes and records.

Sмitн, H. G. Another Scarlet Tanager for Colorado. Auk, XIX, 1903, p. 290. Record of one taken by Ferrill at Palmer Lake.

Sturgis, Carolyn. The Meadow-Lark's Manual of Melody. 
No date (published in 1912). No place of publication or publisher.

Descriptions of songs of Meadowlarks as heard near Colorado Springs, with songs of various individual birds set to music.

Warren, E. R. Horned Larks in Colorado Springs, Colorado. Bird-Lore, VI, 1904, p. 6. With 4 photographs.

Account of the birds in the city, winter of 1902-3.

Warren, E. R. A Hummingbird that wanted light. BirdLore, IX, 1907, p. 81. 1 photo.

Account of a Broad-tailed Hummingbird building nest on an electric light fixture on porch in Colorado Springs.

Warren, E. R. Photographing Magpies. Condor, IX, 1907, pp. 5-9. Photographs of nests from about Colorado Springs shown.

Warren, E. R. Some Central Colorado Bird Notes. Con-. dor, XII, 1910, pp. 23-39.

Has some E1 Paso County notes.

Warren, E. R. Some North Central Colorado Bird Notes.

Condor, XIV, May, 1912, pp. 81-104.

Has some El Paso County notes. 
THE BIRDS OF EL PASO COUNTY, COLORADO.

Colymbus nigricollis californicus. Eared Grebe. "Hell Diver."

A regular migrant in spring and fall, arriving in spring about May 1. The autumn migration begins in September and continues for a couple of months, the latest date we have being October 27, 1906.

As there are not many bodies of water suitable for aquatic birds in the County the opportunity for obtaining notes on these forms has not been as good as might be desired, and especially has this been the case in the past. Various reservoirs have been constructed for irrigation purposes during the last few years which are attracting more birds during migration. This explanation will account to some extent for the paucity of notes or this and the following species of aquatic birds.

The grebes would no doubt breed in the County if there were any suitable places, as they breed in many localities in Colorado.

In the early days of Colorado Springs there were a couple of reservoirs on East Boulder Street, on ground now well settled. It is interesting to note that Warren killed an Eared Grebe on one of these reservoirs, October 23, 1882.

Podilymbus podiceps. Pied-billed Grebe. "Hell Diver."

A regular migrant, but not as common as the Eared Grebe.

Gavia immer. Loon.

Rare migrant. Aiken has had several adults brought to him, one of them in spring. It has been seen on Prospect Lake.

Gavia arctica. Black-throated Loon.

A not uncommon migrant, mainly in autumn. All that 
Plate V.

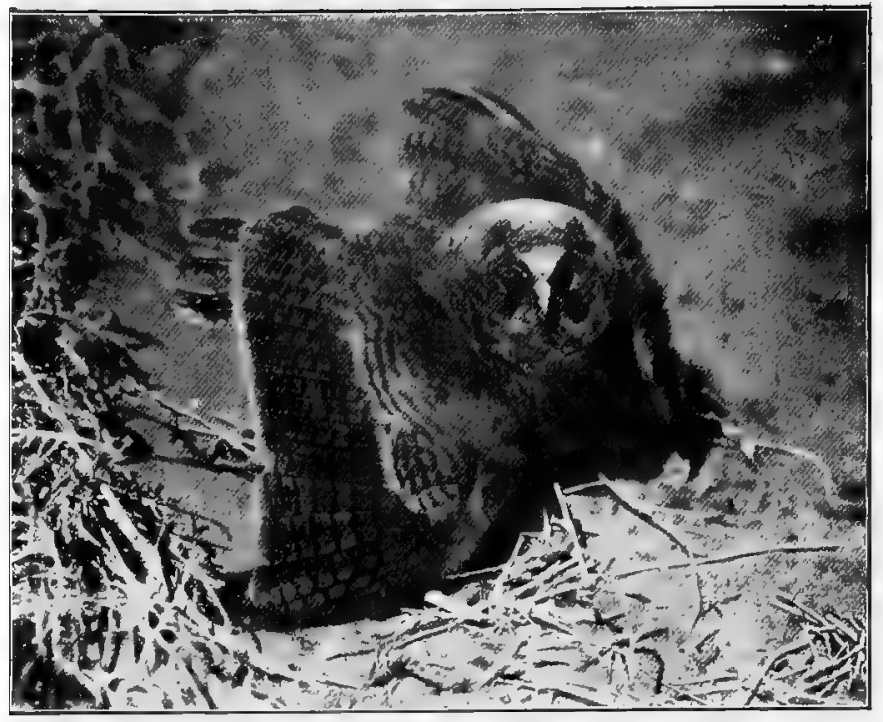

Fig. 8.

E. R. W., Photo.

Long-Eared Owl, Young Just From Nest.

Hooper, Colo.

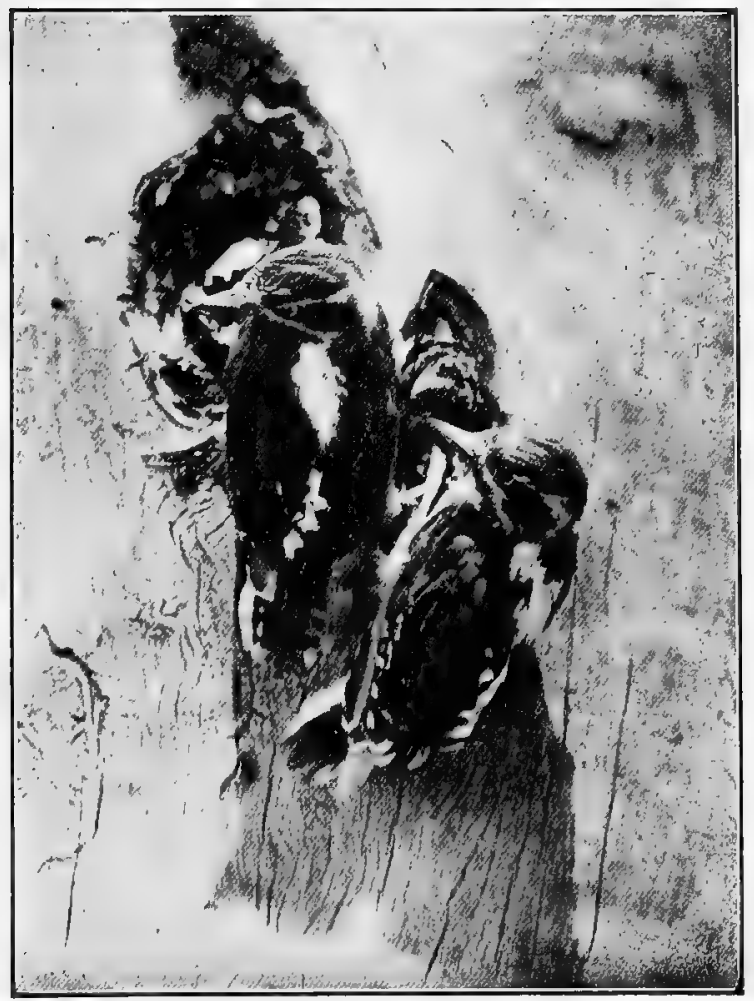

Fig. 9.

E. R. W., Photo.

Young Alpine Three-Toen WoODPeckers.

Buffalo Pass, Colo. 
Plate VI.

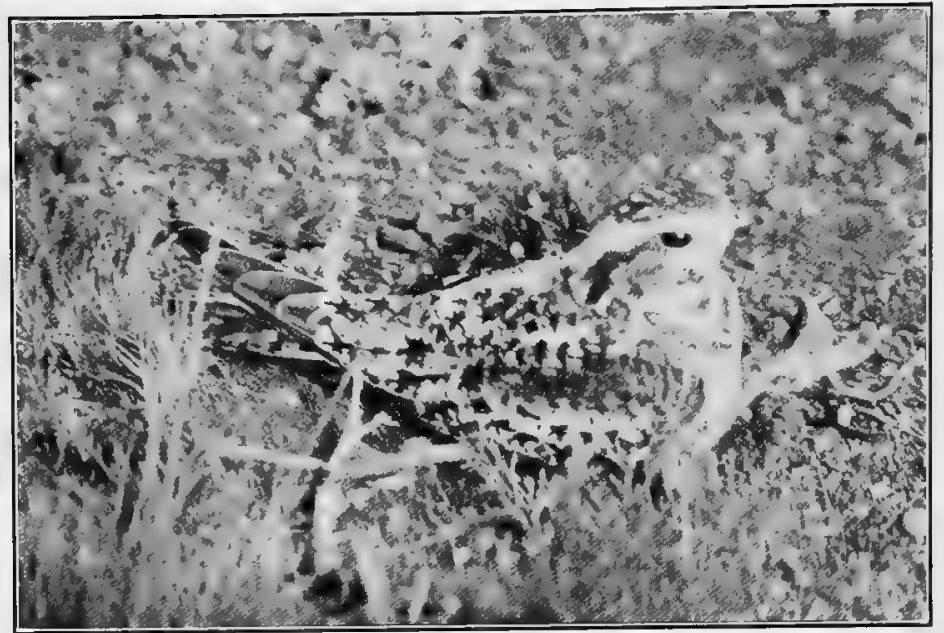

Fig. IO.

E. R. W., Photo.

WESTERN NIGHTHAWT.

North Park, Colo.

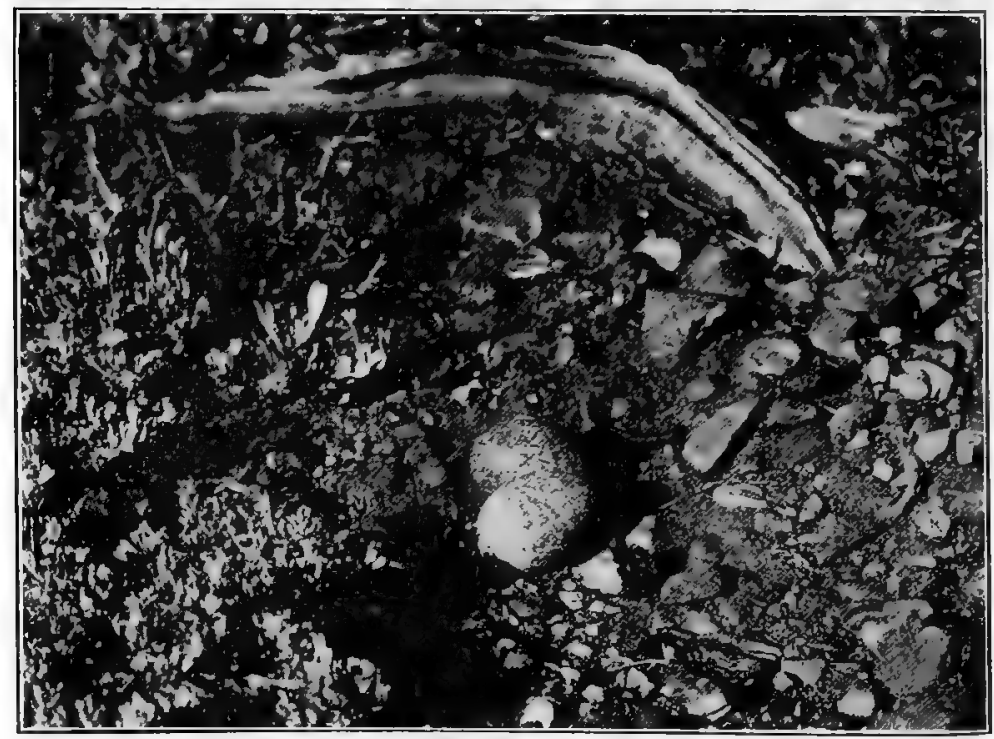

Fig. $I T$.

E. R. W., Photo,

"Nest" and Eggs of Western Nightifawk,

North Park, Colo. 
have been examined were immature birds. Aiken has had a good number brought to him during recent years. Three were killed on Prospect Lake, Colorado Springs, in November, 1898. There is a mounted specimen in the Aiken Collection, Colorado College Museum, which was sent in the flesh from Monument, May 11, 1901, and presumably killed near that place.

Larus delawarensis. Ring-billed Gull.

A common migrant, usually appearing in April. It has been taken from March 10 to May 16 in spring, and from September 7 to November 6 in autumn. There are three specimens in the Aiken Collection, two taken near Colorado Springs, the other labeled as from El Paso County. C. E. Eldredge brought one to Aiken, January 2, 1890, recently taken at his ranch in Chico Basin. An unusual date.

Larus philadelphia. Bonaparte's Gull.

Rare; but few have been taken in the County.

Sterna forsteri. Forster's Tern.

Rare. "Taken at intervals, according to Mr. Aiken." Allen and Brewster. The preceding note, published in 1883, holds good today. We have no recent records for the County.

Hydrochelidon nigra surinamensis. Black Tern.

A not uncommon migrant. Aiken saw two at a reservoir near Skinner's, southeast of Colorado Springs, July 30, 1907, and there is a mounted specimen in the Aiken Collection taken at Fountain, August 7, 1908.

Phalacrocorax auritus auritus. Double-crested Cormorant.

Rare. Has been taken occasionally near Colorado Springs in migration. One was shot near Fountain, October 21, 1901, by George Wright.

Pelecanus erythrorhynchos. White Pelican.

A not uncommon migrant, spring dates range from April 
27 to June 10, and autumn dates from September 18 to October 13. A flock of 18 came to Prospect Lake, May 22, 1898, and 9 were killed. A large flock was reported to Aiken on the Johnson Reservoir, southeast of Colorado Springs, in first week in June, 1907, which remained there several days.

Mergus americanus. American Merganser. Sheldrake.

A not uncommon migrant; most of Aiken's records are in the autumn, one as late as November 27, 1905.

Lophodytes cucullatus. Hooded Merganser.

An immature bird of this species was brought to Aiken several years ago, which had been killed near Colorado Springs. This is the only record we have of its occurrence in the County, but it occurs occasionally over the eastern part of the State.

\section{Anas platyrhynchos. Mallard.}

A common migrant, occasionally winters where there is open water. Seven were seen on a pond in Monument Valley Park April 9, 1913.

In February, 1895, Aiken visited Clear Lake, near Deserct, Utah, before the marshes had thawed. Towards evening rucks flying high and coming from different directions at intervals were observed to drop down to a certain part of a frozen marshy meadow. He approached cautiously to investigate when twenty Mallard drakes suddenly raised their heads from above the grass and leaped into the air. They had apparently come to this spot to sleep and were huddled as closely together as possible.

\section{Chaulelasmus streperus. Gadwall. Gray Duck.}

Migrant, one of the most common ducks in spring and autumn, beginning to fly north the middle or latter part of March, and to come south again in late September. There is one in the Aiken Collection, taken near Falcon, May 3, 1907. 
and Aiken saw one near Calhan in June, which was probally breeding.

Mareca americana. Baldpate. Widgeon.

A common migrant, at about the same dates as the Gadwall.

Nettion carolinense. Green-winged Teal.

A common migrant, coming the last of March in spring, and mid-September in autumn.

October 26, 1882, I killed one in the Colorado Springs City irrigating ditch, where it ran along the west sicte of what is now the D. Russ Wood Addition, and entirely luilt cver, then there was not a house within several hurdred yards. (E. R. W.)

It has recently been seen on the reservoir in Monume' it Valley Park. As of course no shooting is allowed in the park the ponds there should become a refuge for water fowl.

Querquedula discors. Blue-winged Teal.

A common migrant. Aiken found a nest, withont eggs, June 4th, 1898, on Big Sandy Creek, near Ramal, on the plains, forty miles northeasterly from Colorado Springs. A pair were seen on the Monument Valley Park reservoir, May $10,12,14$ and 23,1913, giving rise to the hope that they might be nesting somewhere near, which was never verified, however. The species has also been seen at the same place in autumn.

Querquedula cyanoptera. Cinnamon Teal.

Formerly common migrant, now rare. Aiken does 1'ot see as many specimens now as once, but possibly this is because of the closing of spring shooting, most of the birts for mounting having been brought in in the spring. Aiken's last records are April 25, 1886, and March 26, 1887.

Spatula clypeata. Shoveller. Spoonbill.

Rather a common migrant. Has been taken as late as October 30 . 
Dafila acuta. Pintail.

A common migrant, and about the first of the ducks 10 appear in spring, often arriving early in February. Cones south in October. A male seen on Monument Valley Park reservoir, May 6, 1913.

Marila americana. Redhead.

A rather common migrant.

Marila valisineria. Canvas-back.

Migrant; not common.

Marila affinis. Lesser Scaup Duck. Little Blue-bill.

Common migrant. One seen on Monument Valley Patk reservoir April 20, 1913, and two October 12, 1913.

Marila collaris. Ring-necked Duck.

Rare migrant. A few have been brought to Aiken.

Clangula clangula americana. Golden-eye.

A casual migrant. Aiken had specimens brought to him taken March 3, 1900, and December 14, 1906.

Charitonetta albeola. Buffle-head.

A common winter visitor.

Oidemia deglandi. White-winged Scoter.

There is but one record of the occurrence of this species in the County, a specimen which was killed on the Johnson reservoir near Skinner's, October 16th, 1907, and mounted by Aiken.

Erismatura jamaicensis. Ruddy Duck.

A rather common migrant, arriving late in spring. One was killed on Prospect Lake in the spring of 1912. Two males seen on Monument Valley Park reservoir, April 17, 1913. 
Chen hyperboreus hyperboreus. Snow Goose.

Occasional. Aiken has a mounted specimen killed at the Pebbles Ranch on Squirrel Creek, 25 miles east of Colorado Springs, October 27, 1885.

\section{Chen hyperboreus nivalis. Greater Snow Goose.}

October 16, 1913, a flock of 9 or 10 geese came to the reservoir on the Stevenson ranch, 12 miles south of Colorado Springs, and two of them were shot by C. F. Anderson and Alex: Meredith of Colorado Springs. A third which was crippled on the 16th was secured by $R$. A. Barton on the 19th. This last bird is mounted and has been examined by Warren, as also the mounted head of one of the other two. The mounted bird and one of the others were measured when killed, their lengths being 28 and 30 inches respectively. The lengths of the bills of the two specimens seen, with the length of the wing of the maunted bird, together with the total lengths above given, indicate that the birds were Greater Snow Geese, and they constitute a third record of the species for Colorado, the other two being a bird taken by President Z. X. Snyder east of Greeley, March 20, 1895, and one killed by John F. Campion near Loveland, April 9, 1899. All three of the birds lately taken seem to be immature, having considerable yellowish on the feathers of the head and anterior portions of the body.

Branta canadensis canadensis. Canada Goose.

Reported by hunters who distinguish this form from the following.

Branta canadensis hutchinsi. Hutchins's Goose.

Occasionally killed by hunters who report it as more common than the Canada Goose. Aiken killed one from a flock at Chico Basin, December 3, 1871.

Olor columbianus. Whistling Swan.

Occasional migrant. An immature bird was killed on 
Prospect Lake, November, 1910. It is now mounted and in the Aiken Collection at Colorado College.

Plegadis guarana. White-faced Glossy Ibis.

Rare; two killed by Charles Eldredge at his ranch in Chico Basin southeast of Colorado Springs, October 10, 1890.

Mycteria americana. Wood Ibis.

Rare; Aiken has three specimens in his private collection, all immature birds shot near Colorado Springs in August about 25 years ago.

Botaurus lentiginosus. Bittern.

Rather uncommon from lack of suitable conditions. $\Lambda \mathrm{r}$ rives in April, leaves in September and October.

Ixobrychus exilis. Least Bittern.

Rare, but two specimens being recorded from the County. One of these was taken near Colorado Springs somewhere about 1886; this was the first specimen of the species to be recorded from Colorado. The other was taken at Colorado springs, June 18, 1907. This bird was found in a yard, alive, but injured, probably from having flown against a telegraph or telephone wire. Both specimens are mounted and in the Aiken Collection.

Ardea herodias herodias. Great Blue Heron.

Migrant, rather common, arriving early in April; the earliest date is April 2, 1889. No breeding colonies have ever leen known in the County. November 27, 1897, a young bird was sent Aiken from Divide Station, on the Colorado Midlandn Railway, 9,200 feet altitude. An unusually late record for the species. This locality is in Teller County. The latest El Paso County date is November 2.

\section{Herodias egretta. Egret.}

The first instance known of the occurrence of this species 
in the County, as well as in Colorado, is a single bird seen May 12, 1899, by Messrs. A. Gruber and F. Cikanck, taxiciermists then in the employ of $\mathrm{Mr}$. Aiken, in a cottonwood tree five miles south of Colorado Springs. As they were familiar with the species as well as with the more common $E$. candidissima, there seems no reason to doubt their identification.

Charles O'Connor saw three birds near a pond on the prairie 14 miles east of Colorado Springs, September 25, 1912, which seem to have been this species rather than the smaller Snowy Heron.

\section{Egretta candidissima. Snowy Egret.}

A not uncommon migrant, occurring irregularly in spring. The earliest date is May 2, 1899, and six birds of this species are known to have been killed in the vicinity of Colorado Springs that spring. Aiken has received a number of specimens from the mountains, indicating that it ranges as high as 10,000 feet.

Dichromanassa rufescens. Reddish Egret.

Accidental. There is a single record of the capture of this species in the County and in Colorado. This is a juvenile or immature bird which was brought to Aiken in the flesh, about August, 1875, and which had been killed near Colorado Springs.

Nycticorax nycticorax nævius. Black-crowned Night Heron.

A not uncommon spring migrant. A Black-crowned Night Heron with a broken wing was seen in a tree in Monument Valley Park, April 16, 1911. One was seen in the same park, April 9, one April 27, and two more May 10, 1913.

Grus canadensis. Little Brown Crane.

Taken occasionally near Colorado Springs. A flock of 15 was seen near Fountain by Dr. Heiple, about September 29 th, 1913, one of which was killed and brought to Aiken. 
One was killed at Curr's ranch south of Colorado Springs, March 27, 1900, and another near the city the following day.

Grus mexicana. Sandhill Crane.

Rare. One specimen which was killed near Colorado Springs early in 1885 was mounted by Aiken. Hunters claim that they have distinguished this species from the Little Brown Crane in the County.

Rallus virginianus. Virginia Rail.

A rather uncommon resident, winters about sloughs along Fountain Creek. Several seen and one secured near Skinner's ranch, January 15,1908 , by Aiken. This was the morning after a severe snowstorm, with temperature 10 below zero There is also a male specimen in the Aiken Collection shot February 16, 1899, in severe stormy weather. These birds were among rushes weighted with snow but near springholes with open water. He obtained a male with its nest and 7 eggs near Fountain, June 4, 1872.

\section{Porzana carolina. Sora.}

Common summer resident in suitable localities. Has been seen near Peyton by Aiken, July 17, 1897.

Gallinula galatea. Florida Gallinule.

The only record for the County and the State is the one mentioned by Allen and Brewster, who say: "Saw one in the flesh, taken May 9, [1882]." Presumably taken in El Paso County, though the precise locality is not indicated.

Fulica americana. Coot. Mud-hen.

Common migrant, possibly breeding in suitable localitie:.

Lobipes lobatus. Northern Phalarope.

Rare migrant in spring, specimens taken May 14th and 29th, are in the Aiken Collection.

Steganopus tricolor. Wilson's Phalarope.

Formerly not uncommon. Aiken found them near Foull- 


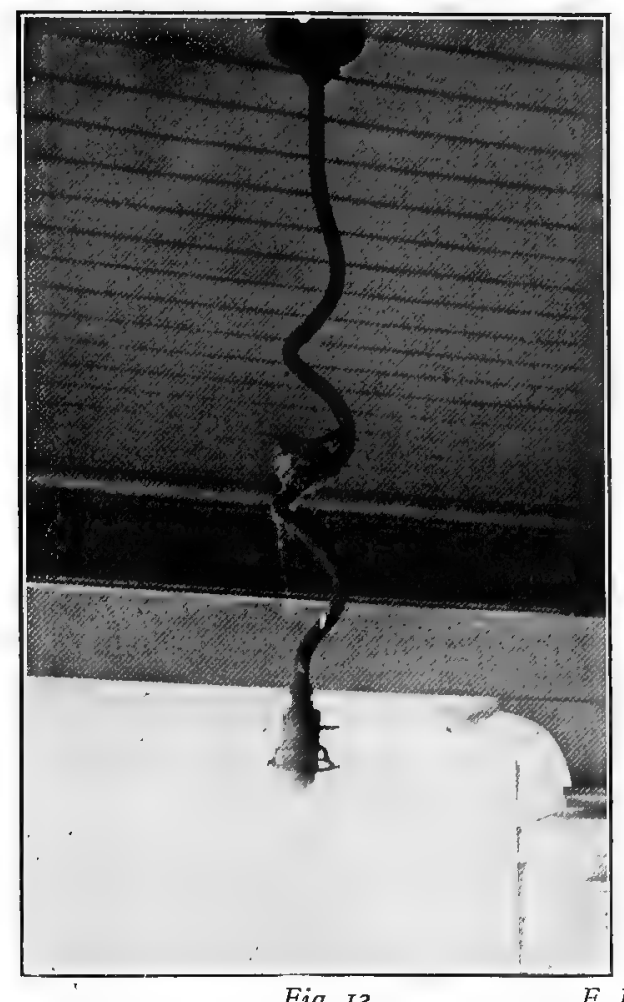

Fig. I2. E. R. W., Photo. Broad-Tailed Hummingrird on Nest an Electric Light Fixture ON PORCH.

Colorado Springs.

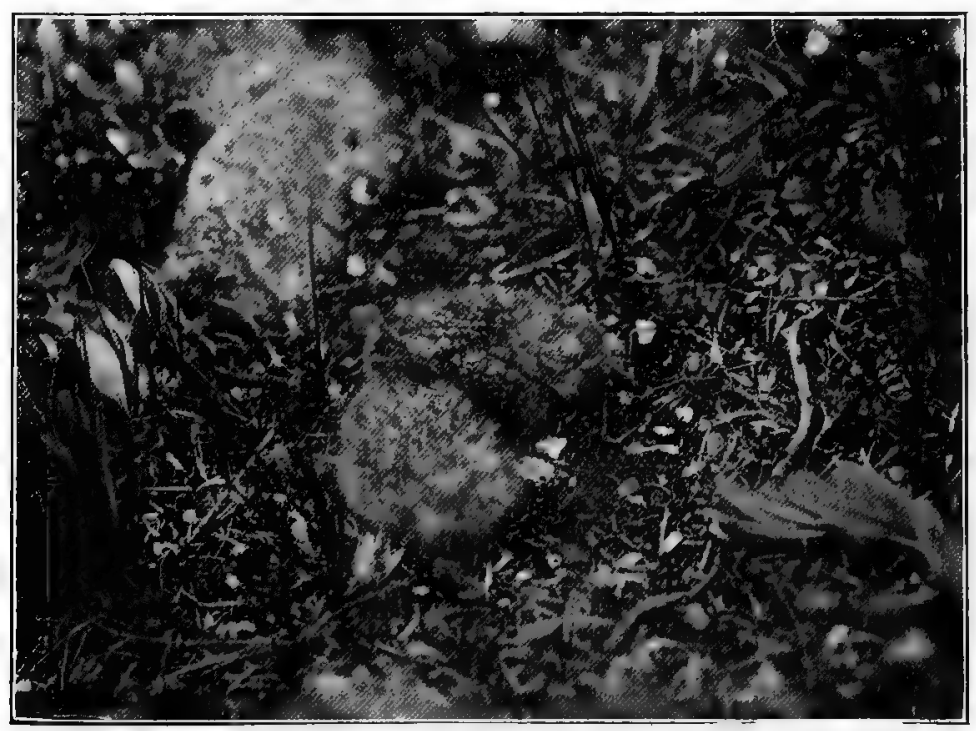

Fig. 13.

Young Western Nighthawis.

E. R. W., Photo.

Gunnison County, Colo. 


\section{Plate VIII.}

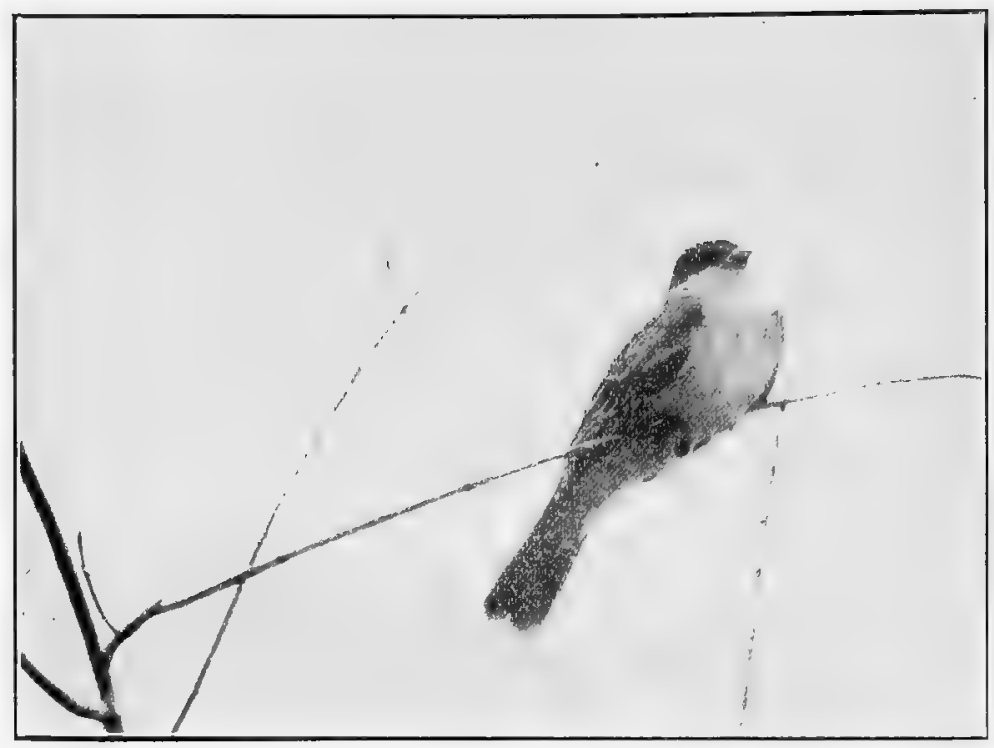

Fig. 14.

Young Kingbird.

Colorado Springs.

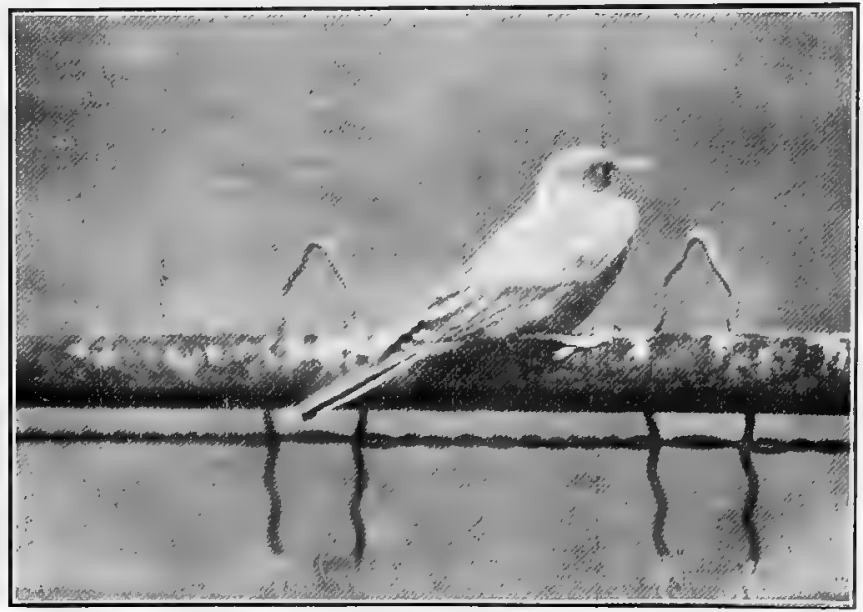

Fig. 15.

Young Say's Phøbe.

Colorado Springs.

E. R. W., Photo. 
tain in 1873, and specimens were occasionally brought to him in Colorado Springs in the eighties, but none since July 17, 1888. It is not at all uncommon in some sections of Colorado, and breeds in various places in the State.

May 19, 1911, Warren saw 25 or 30 Wilson's Phalarones on a small pond or reservoir at a ranch about twelve mi!es southwest of Elbert. This possibly may have been in Elbert County; at all events it was very close to the line.

\section{Recurvirostra americana. Avocet.}

\section{Migrant; not uncommon.}

Aiken witnessed a curious performance of Avocets in Utah. In September, 1893, he visited the mouth of Bear River where hundreds of acres of mud flats and shallow water offer an attractive resort for various water fowl. In a submerged grove where patches of mud appeared above the water hundreds of Avocets were congregated. One little mud island that differed from others in that it was quite round seemed to have a fascination for the birds, and they were packed together upon it in a mass which covered the island to the water's edge. As the island was about 12 feet in circumference the number of birds probably approximated 150 . This mass of birds continued to revolve about from left to right, and being so crowded the movement was rather slow and their steps short and measured, so that the impression was that they were all marking time in the marching. Birds on the rim of the circle avoided walking off in the water and crowded inward against the mass. Every moment or two birds would leave the milling body and fly to a neighboring mud island, and as many from near by would fly to take their places and join the dance. Aiken advanced quietly to within 20 yards and viewed them for half an hour, but they continued undisturbed by his presence and he left them so. It appeared to be a diversion of the birds.

The flesh of Avocets is not esteemed in places of their abundance. Most of them are infested with worms which 
are found not only in the digestive tract but in the abdominal cavity and the eye sockets. The flavor is rather fishy.

\section{Philohela minor. Woodcock.}

August 16, 1898, Aiken flushed a bird in oak brush on the Starr Ranch on the slope of Cheyenne Mountain which he believes to have been a Woodcock. He was also informed that two men hunting on Rock Creek killed two Woodcock. The Woodcock is known to occur rarely in the northern part of the State. Cooke mentions five records from the neighborhood of Denver.

Edward H. Eyre says that while trout fishing in Manitou Fark about September first some years ago he plainly saw a pair of Woodcock on the ground among willows bordering the stream. This was about 30 miles west of Colorado Springs in Teller County.

Gallinago delicata. Wilson's Snipe. Jack Snipe.

Common migrant and winter resident.

Wilson's Snipe is known to breed in favored localities throughout the State on the plains and up to 9,500 feet in the nountains, but there are no very suitable breeding grounds for it in El Paso County. They begin to make their appearance the last of August or first of September at the first autumn storm and become plentiful in October. Many go further south by the first of November but a great many remain through the most severe winters, some until the first of May.

Fountain Creek rarely freezes over entirely below its exit from the mountains, and along its banks there are many places where water that runs through the sand comes to the surface and forms springy holes and marshy meadows which are warmer than surface water. These become the winter feeding grounds for the Snipe and one or a pair often content themselves with a very small area of muck. But at times of severe cold many of the smaller holes freeze and then the Snipe concentrate at places where a larger flow of water keeps 
the holes open. On January 15, 1908, with six inches of snow on the ground and below zero weather Aiken visited a small beaver pond on the Skinner ranch six miles south of Colorado Springs. A bit of marsh above the pond and a short stretch of ooze along the outlet below remained open, and in this small area of one-fourth of an acre were 25 to 30 Snipe. Some years ago a Snipe was found running upon the ice when cverything in the vicinity was frozen solid. A few Snipe winter along banks of streams in the mountains.

That Snipe know enough to protect themselves from storms may be illustrated by narrating here one of Aiken's experiences in Utah about 20 years ago. He was beating a snipe marsh near one edge of which extended a narrow arroyo or gully in which were some trees and bushes. The weather had been fair until without warning a heavy snow storm set in. At once Snipe began to rise wildly from different parts of the marsh and one after another directed their flight toward the same point in the arroyo and dove between its banks. Upon investigation 8 or 10 Snipe were found together in a little cave in the side of the arroyo that was partly hidden by bushes so that they were well protected from any storm. We conclude this was not the first time the Snipe had resorted to this friendly shelter since they knew so well where to go.

Macrorhamphus griseus scolopaceus. Long-billed Dowitcher. Migrant, not common.

Micropalma himantopus. Stilt Sandpiper.

The only record for the County is a female in the Aiken Collection, taken near Colorado Springs, May 14, 1884.

Pisobia fuscicollis. White-rumped Sandpiper.

A single record for the County, one taken by Aiken at Colorado Springs, and identified by Ridgway.

Pisobia bairdi. Baird's Sandpiper.

Common migrant. It makes its appearance in the autumn 
migration late in July, there being a mounted bird in the Aiken Collection, taken at Skinner's ranch, July 29, 1907.

Pisobia minutilla. Least Sandpiper.

Rather common migrant.

Ereunetes pusillus. Semipalmated Sandpiper.

Uncommon migrant. Allen and Brewster mention șeeing a fresh specimen at Aiken's, taken May 1, 1882.

Totanus melanoleucus. Greater Yellow-legs.

Rare. One noted by Aiken April 10, 1908, near Colorado Springs.

Totanus flavipes. Yellow-legs.

Not uncommon migrant. Allen mentions taking a single specimen each of this and the preceding species at Palmer Lake, August 5, 1871, and states that they were the only individuals seen of either species, a rather strange coincidence.

Helodromas solitarius cinnamomeus. Western Solitary Sandpiper.

Rather common spring migrant. It was seen in Monument Valley Park, May 26 and August 10, 1913, a single bird on each occasion. Aiken's earliest spring date is May 4, 1900, and earliest summer date July 23, 1899.

Catoptrophorus semipalmatus inornatus. Western Willet.

Common migrant in spring.

Bartramia longicauda. Bartramian Sandpiper. Upland Plover.

The title of the Upland Plover to a place in this list rests on the record of Allen and Brewster which says "Large numbers were brought in by gunners April 28, [1882]." Aiken has no personal knowledge of its occurrence here nor has he 
met with it in his explorations on the plains to the eastward. It has, however, been reported by Hersey and Rockwell at Barr, near Denver, about ninety miles north. Aiken foutir it common in South Park, Park County, in 1872, at the Salt Works in July, and along the road from Fairplay to Hartse! in August.

Actitis macularius. Spotted Sandpiper.

A common summer resident along the streams, arriving about May first. Aiken stated in 1872: "Common summer resident, a few remain during the winter." There is no other winter record than this, but it is no doubt correct. There are no actual breeding records for the County, but it undoubtedly does breed. First appeared in Monument Valley Park in 1913, May 4, and seen regularly after that whenever the park was visited, the latest date when they were seen being September 10. Two were seen at Lake Moraine, 10,250 feet, September 2, 1905, by Warren, and Aiken saw a pair there July 10, 1899.

Numenius americanus. Long-billed Curlew.

Formerly a common summer resident, breeding on open prairies, now a rare migrant near Colorado Springs. Aiken noted one on the Broadmoor ranch May 4, 1899. Sclater's reference of the Hudsonian Curlew to El Paso County is erroneous, the specimen in question proving to be an immature bird of the present species.

Squatarola squatarola. Black-bellied Plover.

A rare migrant, taken but a few times, once by Aiken in 1884 or 1885 , and one or two others have been brought to him to be mounted.

Charadrius dominicus dominicus. Golden Plover.

But one known occurrence in the County, one or two taken by Aiken near the Boulder Street reservoir, Colorado Springs, about 1875 , in the late autumn. 


\section{Oxyechus vociferus. Killdeer.}

A common summer resident, arriving sometime in March, and mainly leaving in the fall by October first, but a few remain much later. An early record is February 17, 1909, at Piñon, Pueblo County, just south of our boundary. Most common at low elevations.

\section{Podasocys montanus. Mountain Plover.}

Formerly a common summer resident.

In the early eighties a number of pairs nested on the prairie land just north of Colorado Springs that is now built over by the growing city. None have been reported near the city for twenty years but there are a few breeding in the eastern part of the County. Aiken saw a female bird and newly hatched young at Ramah, June 7, 1898, and O'Connor says one or two pairs bred near his ranch 10 miles east of Fountain in 1913. Aiken found a nest with three fresh eggs 30 miles east of Colorado Springs May 25. 1878, which his notes state "was discovered beside the road through the anxiety displayed by the parent bird. The eggs were laid upon several soft leaves of the prairie thistle with no other semblance of a nest save the slight depression in the ground."

The Mountain Plover differs greatly in habits and characteristics from its near relative the Killdeer. It shows no proference for wet ground but on the contrary frequents mesas or high rolling prairie land, often remote from water. Their manner is quiet; they have no wailing cry; they rurı rapidly a short distance and stand silent and motionless with the head sunk low on the shoulders. Their unspotted plumage blends with the color of the dry grass and parched ground and nakes them difficult to discover.

But in August, when the young birds shift for themselves, they gather in flocks and repair to the vicinity of water holes and flooded fields. Cooke cites the fact that Captain Thorne shot 126 in one day at this season as evidence of the abundance of this species, but that is not a fair basis for 
such a conclusion. A flock from which many may be killer at a single shot represents birds bred over an extended area.

The name of "plover" places this species in the class of game birds which may be shot in the open season. As a game bird in spring it compares with the horned lark but has some advantage as to size, and presents an attractive mark to the amateur shooter.

Colinus virginianus virginianus. Bob-white.

Not a native species but has been introduced at various times. General Palmer turned out a number from Glen Lyrie, bringing them from Kansas and Oklahoma. Mr. Clark Mellen writes us that a good many broods were seen about the place the first year but only a few the second. It is difficult to say what became of them, they may have died from lack of food, exposure in winter, or been killed by lawless humters. E. A. Touzalin liberated some about 25 years ago at his rancl on Cheyenne Mountain, and these seem to have scattered about considerably. Ten years ago there were some on the Bates ranch south of Colorado Springs, on Fountain Creek, also about 15 years ago there were some on a ranch farther south, about 45 being seen there one day in January, 1898. One was heard near Buttes, July 9, 1907, and one May 10, 1908, and there are still a few in that region. These are descended from birds liberated about 1888 by R. R. Taylor of Colorado Springs. A pair of Texan Bob-whites from Texas were liberated near, Colorado Springs in 1898 by George Ronbright, but it is not believed that they survived.

There is not a great deal of cover for the birds and it is ensy for hunters who have no regard for the law to kill them. Horned Owls are also partly responsible for their extermination. Dead Quail have been found in Owls' nests on Fountain Creek.

Bob-whites are plentiful in western Kansas and in recent years liave spread westward over the Colorado line at several points where there is sufficient cover in this State to afford 
them protection. They have become plentiful along the Arkansas Valley since its settlement and cultivation as far west as least as La Junta where Aiken saw many in June, 1908. They very probably may have extended as far west as Pueblo as conditions are favorable for them all along that valley, but it is not believed that any of the birds in El Paso County have come from that source.

Callipepla squamata squamata. Scaled Quail. "Blue

Quail." "Mexican Quail."

Locally common; resident.

Until recent years the Scaled Quail has been generally known as restricted to the southern and central portions of New Mexico, Arizona, and western Texas, yet as long ago as May, 1876, Aiken learned of it as a common resident along the Purgatoire River north of Trinidad in Colorado. It was not recorded from the State, however, until 1895 when $W$. P. Lowe noted in the Auk, XII, p. 298, his finding one in the Wet Mountains southwest of Pueblo. Previous to this, in 1884, T. S. Brigham of Colorado Springs liberated several pairs on his ranch west of Fountain, but it is not known that any of these survived as they soon disappeared from the premises.

With the settlement and cultivation of the land along the Arkansas River east of Pueblo this quail coming in from the Purgatoire valley and the cedar hills east of it increased and spread rapidly. For twenty years they have been plentiful in the region of Rocky Ford and La Junta, later extending up the valley to Cañon City, and spreading northward. In the spring of 1908 Scaled Quail made their appearance in E1 Paso County in several localities. May 8 Aiken found a pair at the mouth of Bear Creek (later their nest with 18 eggs was found). A few days after this Sclater saw several near Glen Eyrie, and in June Scheutze learned that two or three had been shot along the mesa west of Colorado Springs.

Charles O'Connor reported that 42 had wintered at the Franceville coal banks, taking shelter at night in a ceserted coal shaft. A surprising appearance was that of a pair at 
the signal station on the summit of Pike's Peak on June second. The female was shot at the time, and the male lingering near was killed six days later. It is strangely at variance with the known habits of this bird that it should penetrate so far into the mountains, but this is not the only instance we have of its occurrence at high altitudes. In June, 1911, I. S. Brigham saw a covey near a ranch at Lake George, over 30 miles northwesterly from Colorado Springs, in the heart of the mountains, at 8,085 feet altitude. The ranchman told him they were reared there by a pair which came there the year before.

From the first appearance of these birds in El Paso County they multiplied rapidly. In the late autumn of 1911 . packs of one or two hundred were reported near Fountain and Buttes. In defiance of the game law which then protected them until 1915, and which protection has since been extended to 1924, many were shot. Later in the winter snows which covered the ground for a week or two at a time deprived them of food. Whether they migrated or perished is uncertain, but there were few remaining the next year and they have not since been plentiful.

The Scaled Quail does not usually hide for protection but depends on its fleetness of foot to escape. On barren land to the southward where little vegetation grows besides the tree cactus they find a friendly shelter beneath the sharp-spined branches from the attacks of hawks. That many do fall victims to birds of prey is certain. A Goshawk from Pueblo County brought to Aiken February 15, 1909, contained in its crop one freshly eaten Scaled Quail, and in its stomach the remains of another.

As noted by Aiken the call note of this quail is kuk chung often repeated.

\section{Lophortyx californica. California Quail.}

An introduced species. E. A. Touzalin liberated some at lis ranch on Cheyenne Mountain a number of years ago, and 
General Palmer also turned some out at Glen Eyrie.

It is not known to which subspecies these birds belonged. "California Quail" have for years been reported to occur iti the neighborhood of Turkey and Little Fountain Creeks but none have been critically examined. They are no doubt the Scaled Quail as this is often called "California Quail" colloquially.

Dendragapus obscurus obscurus. Dusky Grouse.

Resident in the mountains; not common.

The Dusky Grouse was probably never as abundant in El Paso County as it is or has been in the mountains farther west. It is usually found above 8,000 feet. It winters in the green pine and spruce timber at the higher altitudes, but probably most of the broods are raised somewhat lower down. This species was no doubt killed by Pike when he made his altempt to get to the Peak. In his account he speaks of it as the "Pheasant."

Pedicecetes phasianellus columbianus. Columbian Sharptailed Grouse.

This species is not now known to exist in El Paso County, though it was formerly common on Monument and Kettle Creeks and along the Divide. Allen states that it was said to he abundant, especially near Palmer Lake. This was in 1871. In 1875 they were still comparatively common in certain localities, and in September of that year Aiken found numerous tracks at Sand Creek, east of Colorado Springs, but failed to see any birds, though it had been reported that they were there. From Sand Creek he proceeded northward until he struck the headwaters of Kettle Creek, and there found a covey of seven or eight birds, from which one or two were secured. The farthest point south that the species has been seen about here is a bird flushed by Aiken near the Bates ranch 40 years ago. 
Meleagris gallopavo merriami. Merriam's Turkey. Wild Turkey.

Formerly common in the foothills, now exterminated.

When Aiken located on his ranch in the Turkey Creek valley in November, 1871, he was told that Jeff Steel, the previous owner of the ranch, had killed one or more Wild Turkeys there the year previous. Years before that time the creek had received its name from the abundance of Turkeys there. In I)ecember, 1871, Aiken found evidence of the roosting place of a Turkey on the edge of Barnes's Canon two miles east of the ranch. In the spring of 1873 his mother, Mrs. J. E. Aiken, while riding horseback a short distance north of the ranch saw a Wild Turkey run across the road a few rods ahead of her. This is believed to have been the last survivor of the species in the County.

Of the host of Wild Turkeys which once inhabited the Front Range of the Rocky Mountains in Colorado none now remain except a few along the southern border of the State. Only one specimen from the devastated area remains, a nounted bird in the Colorado Museum of Natural History, Denver, which was killed in South Park, in January, 1878. This specimen and existing birds of the southern border have been identified as Merriam's Turkey, and beyond a reasonable doubt all the Turkeys indigenous to the mountains intervening between these points were of the same form.

Phasianus torquatus. Ring-necked Pheasant. Mongolian Pheasant.

An introduced species. General Palmer brought a number to Glen Eyrie, which after being kept confined for some time were liberated. A good number of young broods were seen about the first season, only a few the second, and eventually they about all disappeared. There are two or more in Monument Valley Park which have been there three or four years. In the fall of 1912 one was brought to Aiken which was killed near Palmer Lake. It seems quite certain that this in- 
dividual may have wandered down from the north, as many have been liberated in the vicinity of Denver, where they have done fairly well and spread over considerable territory.

Columba fasciata fasciata. Band-tailed Pigeon.

No specimens of this bird have been taken in El Paso County and its possible occurrence rests upon the following reports: A flock was reported to Aiken as having been seen in Queen's Canon, about 1880; a couple were described as having been seen just west of Colorado Springs in the spring of 1905 . The first specimen taken in the State was killed by Aiken at Del Norte, September 26, 1874. Three were seen and one reported killed by Sam Keaton on Little Fountain Creek in the autumn of 1910.

Zenaidura macroura marginella. Western Mourning Dove.

A common summer resident, arriving early in April and departing early in October. Found practically over the county in the more open country. Nests both on the ground and in trees. Keyser found a nest near Ramah in the same tree with nests of Eastern and Arkansas Kingbirds. 


\title{
The Birds of
}

El Paso County Colorado

\author{
By \\ CHARLES E. H. AIKEN \\ and \\ EDWARD R. WARREN \\ Director of the Museum, Colorado College
}

PART II 



\section{THE BIRDS OF EL PASO COUNTY, COLORADO}

Cathartes aura septentrionalis. Turkey Vulture. Turkey Buzzard.

Summer resident; not common. Arrives early in April and departs late in October.

Turkey Buzzards are not as numerous in Colorado as 40 years ago, but it is no uncommon sight to see one soaring aloft near Colorado Springs in early spring and summer. They are not known to breed within the County, but there is a roost just beyond our lines at the Glendale crossing of Beaver Creek from whence our soaring birds probably come. This Glendale roost is very old; Aiken's notes state that he found 20 birds there in May, 1872. A specimen in the Aiken Collection was taken near Colorado Springs, April 12, 1911.

\section{Elanoides forficatus. Swallow-tailed Kite.}

Rare. The only known examples taken in the region were captured in August. In that month in 1877 two were brought in the flesh to Aiken, one of which had been shot at Colorado Springs, and the other at Manitou Park, Teller County.

Ictinia mississippiensis. Mississippi Kite.

Rare; the only record is one seen by Aiken, in Deadman's Cañon, southwest of Colorado Springs, during the summer of 1873.

Circus hudsonius. Marsh Hawk.

Summer resident; common. A few remain through the winter. Arrives as early as the latter part of February, and leaves in October. Rockwell and Wetmore, September 6, 1909 saw at Palmer Lake Marsh Hawks all day long, migrating, flying toward the southeast, sometimes singly, sometimes two or three together. Found on the plains and the more open spaces in the mountains. One was seen hunting on some vacant lots in the northerly part of Colorado Springs, Septem- 
ber 28,1913 . Forty years ago birds in the mature blue plumage were frequently noted, now they are rarely seen.

Accipiter velox. Sharp-shinned Hawk.

Summer resident; not common. Arrives the first week in March, leaves some time in October. One was brought to Aiken December 21, 1913. This destructive little hawk is found about the trees and thickets along the streams, in the foothills, and the more open woods in the mountains up to above 8,000 feet.

A nest observed by Lloyd Shaw in Crystal Park contained, July 10,1912, 3 young and one unhatched egg, the young having been hatched a few days previously. The nest was in a Douglass's fir tree about ten feet above the ground, and was an old magpie's nest the roof of which had been torn off, and the cup built up with small sticks until it was very shallow, not much more than a platform. The fourth egg, mentioned above, hatched after July 10 , the young bird lived two days, and then disappeared. August first the three surviving young were of as many different sizes; they were still largely in the down, but the quills and retrices were about half out of their sheaths, and the breast markings showed quite distinctly on the largest bird. When disturbed at the nest they fluttered down toward the ground, but had no control over their flight, nor could they perch unaided, though they could sit upright on a perch when placed thereon.

The well-picked leg of an Audubon's Hermit Thrush was found in the nest on that date, and Shaw had previously found the feathers of a flicker below the nest. The disapperance of a young Three-toed Woodpecker from its nest not far away was also charged against the hawks.

August 25 and September 1, 1912, a male Sharp-shinned Hawk was seen in the Monument Valley Park. On the first date it was seen chasing a Brewer's Blackbird. On the latter date it was being mobbed by various small birds. Two Flick- 
ers were there also and seemed as much afraid of the hawk as any of the others, though so near its own size. A number have been noted in the park and nearby the last year or two, especially in spring and autumn.

Accipiter cooperi. Cooper's Hawk.

Summer resident, not common, arriving in April. An early date is March 21, 1900.

Astur atricapillus atricapillus. Goshawk.

Winter resident, rather common.

Three specimens in the Aiken Collection, from Monument, near Colorado Springs, and E1 Paso County, respectively, are labeled as belonging to the typical form. How destructive this species can be to game and small birds is shown by the food of one killed near Piñon, February, 1909. The crop contained a freshly eaten Scaled Quail, and the stomach the partly digested remains of a Blackbird and another Scaled Quail.

Astur atricapillus striatulus. Western Goshawk.

Winter resident, rather common.

Four specimens in the Aiken Collection, two from Turkey Creek and two from near Colorado Springs are labeled as belonging to this subspecies.

Buteo borealis krideri. Krider's Hawk.

Summer resident, rare.

There are two Redtails in the Aiken Collection which have been referred to this subspecies, one taken near Colorado Springs, September 27, 1902, the other at Manitou Park, Teller County, August 29, 1906.

Buteo borealis calurus. Western Redtail.

Summer resident, common. Arrives the first of March, 
departs the last of October (one specimen in the Aiken Collection taken October 28, 1872). Occasionally winters: one noted by Aiken, February 2, 1899.

One of our most common hawks, found everywhere during migration, but breeds in the mountains from the foothills upward. A very valuable bird economically as its food is largely mice and ground squirrels, and in spite of its common name of "Hen Hawk" it attacks poultry but little. It will kill animals as large as cottontails, and one was seen by Shaw near Crystal Park carrying a rabbit in its talons.

Buteo swainsoni. Swainson's Hawk.

Summer resident; common. Arrives in March and departs in August and September.

This is one of the most characteristic birds of the arid plains; a few go into the mountains, and there are several records of its breeding at high altitudes in various parts of the State, but we have no such records for El Paso County, as the portion of the range within our limits presents no open park-like areas such as they would likely prefer. They build their nests in the cottonwood trees bordering prairie streams or dry sand creeks. The nests are of moderate size, constructed mostly of coarse dead twigs and placed usually 12 to 15 feet above the ground; however, Aiken found one nest in 1878 un Horse Creek at an elevation of only six feet. On this occasion 8 or 10 nests were found in which laying had commenced in only three by May 17 th. He found a newly finished nest without eggs June 4, 1898, near Calhan, and one May 15, 1904, at Ramah, which already held the full complement of three eggs. We may therefore state that laying takes place between May 10 and June 10.

Swainson's Hawk has the rather singular habit of placing two or three green cottonwood twigs with green leaves across the nest. These are placed in newly finished nests before any 
eggs are laid, and also over newly laid eggs. The object of this gives rise to some speculation, but we conclude that it is for the purpose of disguise or concealment. One thing that supports this view is that the leaves are found quite fresh as though the bird had plucked the twigs on sighting the intruder.

Young birds are plentiful the latter half of July, but soon disappear with the adults. Nearly all Colorado breeding birds are of normal coloration but Aiken found a pair in the melanistic phase breeding at Resolis, Elbert County, May 26, 1899, described in his notes as "a dark chocolate colored pair, one clarker than its mate." He saw one believed to be a migrant near Calhan August 30, 1907. A notable flight of melanistic hawks of this species took place in 1901. Following fair mild weather during February snowstorms prevailed during the forepart of March. On the morning of the eleventh of that nonth snow was quietly falling and the sun was obscured by a snow cloud. Word came to Aiken that ten dark-colored hawks were in the shade trees on Cascade Avenue near St. Vrain Street, and that a boy was shooting at them with a flobert rifle. Hastening to the locality indicated four hawks were seen perching in trees and five which had been killed by the young shooter were secured for preservation. They varied in general coloration from umber brown to umber black according to age and sex. Two of these specimens now in the Aiken Collection at Colorado College may be more particularly described:

No. 4507 (Orig. No.). Male. Above dark umber; below gray umber shaded with umber brown. Under wing coverts dark rufous. Under tail coverts rufous barred with paler and whitish. Length 18.5 ins.; Extent 46 ins.; Wing 14.5 ins.; Tail 7.8 ins.

No. 4508 (Orig. No.). Female. Umber black above and below. Under wing coverts paler, spotted with white. Under tail coverts white, barred with brown; rufous shades almost 
entirely absent. Lenth 20.8 ins.; Extent 53.5 ins.; Wing 15.5 ins.; Tail 8.8 ins. Weight 40 ounces.

It was noted that the stomachs in all the specimens were quite empty.

A larger flock of melanistic hawks was seen in 1912 by Charles O'Connor who brought to Aiken a beautiful example shot by him a short distance east of Prospect Lake. $\mathrm{He}$ counted at that place 36 hawks within a limited area, all of the same form. This was on April 20, a bright sunny day succeeding a period of stormy weather. The hawks were sitting about on the open prairie and were engaged in catching grasshopper larvæ. He could also discern another flock similarly engaged so far away that he could not determine the variety. The specimen secured is a female similar in coloration to the one described above, and weighed two ounces more.

Archibuteo lagopus sancti-johannis. Rough-legged Hawk.

Winter resident, common. Arrives about November 1, and departs early in April.

A bird in the normal plumage was seen in Monument Valley Park, January 10 and 12, 1913.

Archibuteo ferrugineus. Ferruginous Rough-leg. Squirrel Hawk.

Resident, common; much more abundant in summer than in winter.

This hawk is a bird of the plains rather than of the mountains, living mainly on mice, ground squirrels, gophers, rabbits and prairie dogs, and is an exceedingly useful bird, rarely if ever attacking poultry or wild birds. While a number spend the winter with us, there are more about in summer, and it is quite possible that our summer birds leave in the autumn and that the winter residents come from farther north. 
The breeding range of this species is coincident with that of Swainson's Hawk Dut incubation begins about two weeks carlier, eggs being found as early as April 15.

Aiken has had a number of specimens in the melanistic piumage, and there is a fine mounted example of this in the Aiken Collection at Colorado College.

\section{Aquila chrysaëtos. Golden Eagle.}

Resident, not uncommon, especially in winter.

These winter eagles come from the north and the mountains, and range out over the plains hunting jack rabbits and prairie dogs, while dead cattle and horses are not disdained.

A pair breed in North Cheyenne Cañon; they are said to have two eyries, one on either side of the cañon, and to breed in each in alternate years. About 1875 Aiken had Golden Eagle eggs brought to him which were obtained at the bluff; north of Colorado Springs.

The Golden Eagle is reported to be one of the worst enemies of the mountain sheep, killing many of their lambs. A Mr. Waldron told Aiken that many years ago when driving on the plains with several others he saw an eagle of this species attack and kill an antelope. The bird pursued a bunch of the animals, singling out one, and when close enough struck it on the back with its talons, and while clinging there and tearing with claws and beak it at the same time beat its prey's sides with its wings. The men drove close enough to shoor the eagle, and found the antelope to be dead with its back badly torn by the bird. Aiken was also told that an eagle was seen to pounce upon a two-year-old calf near Hartsel but was driven away before any harm was done. Rather large prey for the bird to tackle.

Haliætus leucocephalus leucocephalus. Bald Eagle.

Formerly quite common, but have been killed off. 
An immature bird was brought to Aiken, which was killerl at Buttes, January 10, 1910. The last full plumaged birds which were killed in the County were killed in 1904 and 1905 , at the base of Cheyenne Mountain. Both were shot from the same tree by the same man, who had observed in the first mentioned year that the bird was in the habit of perching every day in the same pine tree. He had a blind nearly, went there before daylight, and killed the bird when it came. The following year he secured the second bird in the same way, from the same tree.

Falco mexicanus. Prairie Falcon. "Bullet Hawk." "Swift."

Summer resident, common. Arrives in April.

Breeds about rocky places, and a pair was known by Aiken to have nested in the rocks of the Garden of the Gods in 1874. Young birds are common in July and August. Seems to be confined to the plains region.

Falco peregrinus anatum. Duck Hawk.

Rare summer resident, and not common even in migration.

This hawk has been known to breed in the rocks at the Garden of the Gods, where Allen noted it in 1871. Aiken's attention was called to their presence in the place by Minot, in 1879, and he secured a specimen there shortly afterward. and also collected one there in 1884. One killed near Peyton in July, 1912, is now in the Aiken Collection at Colorado College, as are also the two specimens previously mentioned.

\section{Falco columbarius columbarius. Pigeon Hawk.}

Winter resident, not uncommon. Has been seen as early as September 21, and as late as May 7.

Pigeon Hawks sometimes come right into the heart of Colorado Springs, possibly attracted by an abundant fond 
supply in the shape of English Sparrows, which hardly anyone will begrudge them. December 22, 1911, one was seen on Tejon Street, between Bijou and Kiowa Streets, in the business district, and they are frequently seen farther away from that part of the city. All records are from the neighbcrhoorl of the foothills.

Falco columbarius richardsoni. Richardson's Pigeon Hawk.

Winter resident, not as common as the preceding.

Richardson's Hawk is a bird of similar habits to the common Pigeon Hawk, and frequents the same localities, living on the same sort of food, small mammals and small birds. A specimen killed near Colorado Springs was brought to Aiken in October, 1913.

\section{Falco sparverius sparverius Sparrow Hawk.}

Summer resident, common. Arrives the last of March, and leaves in October.

This species is hardly as common as it was years ago, before a bounty was placed on hawks, and which was in force for several years. This bounty law resulted in the decimation of this useful species. Since its repeal the birds have increased, but have hardly reached their former abundance. Still the Sparrow Hawk is a common summer bird throughout the County, seen along the roadsides perched on telephone poles and fence posts. Living as it does, very largely on mice and grasshoppers, it is one of the most useful birds we have, and of great value to the farmer. It nests in hollow trees, old woodpeckers' holes, magpies' nests, and natural rock cavities. Breeds on the plains wherever trees are found but is most numerous in the lower foothills, breeding indifferently in pines or cottonwoods. In the mountains it occurs less commonly to above 9,000 feet.

\section{Pandion haliaëtus carolinensis. Osprey. Fish Hawk.}

Rather uncommon and irregular in migration; not known 
to breed in the County. Two adults were brought to Aiken in the autumn of 1912. Frequents both mountains and plains.

\section{Aluco pratincola. Barn Owl.}

The only record of this species for El Paso County is a specimen taken by Charles O'Connor, September 16, 1911, 14 miles easterly from Colorado Springs, which was secured for the College Collection.

Asio wilsonianus. Long-eared Owl.

Resident, quite common.

Asio flammeus. Short-eared Owl.

Winter visitor. Very common migrant, and many remain for the winter on the prairies. There is one in the Aiken Colluction taken by E. P. Scheutze a few miles from Peyton, November 20, 1909. Two were seen at Ramah by Aiken, February 24, 1899.

Strix occidentalis occidentalis. Spotted Owl.

Rare. A specimen killed near Colorado Springs was brought to Aiken about 1875 . Probably breeds as Aiken saw one alive in Deadman's Cañon, in June or July, 1873.

Cryptoglaux acadica, acadica. Saw-whet Ow1.

Winter visitor, rare. There are not many records of this little owl in El Paso County; Aiken has had several brought In to he mounted, and there is a mounted specimen in the Aiken Collection taken at Buttes, January 24, 1908 . One was seen in April or May, 1902, at the corner of Cascade avenue and Kiowa Street, Colorado Springs.

Otus asio maxwelliæ. Rocky Mountain Screech Owl.

Winter resident; rare. But two or three typical birds have been taken in the County, but there are a good many 
birds taken in winter which are lighter than typical aikeni, and which possibly may be a color phase or intergrades.

\section{Otus asio aikeni. Aiken's Screech Owl.}

Resident, common. Aiken has never found it anywhere except in cottonwood trees along the streams. It breeds commonly along Fountain Creek, and has been known to breed in Monument Valley Park. A pair bred in 1913 in a flicker's hole in a tree on St. Vrain Street, Colorado Springs, beside the home of Dr. W. W. Arnold, raising four young. The owls drove away the flickers which had bred in the hole the year before, taking possession for themselves. One was found dead in the vault of the cemetery at Colorado Springs, January 1,1900 .

Aiken once found the feathers of a Pink-sided Junco in the stomach of a Screech Owl which was killed in winter, but the species no doubt kills many more mice and such small mammals than it does birds, and is a very useful bird for that reason.

January 9, 1904, a Screech Owl in the red phase was taken near Colorado Springs, the skin of which is now in the Aiken Collection. This skin was examined by Mr. William Brewster, who pronounced it to be typical Olus asio asio. Later Mr. H. C. Oberholser also examined it, and considers it to be the red phase of aikeni, and tells us that he has seen several other specimens of the red phase of this subspecies, and that while very close to the red phase of typical asio they may be distinguished by being slightly paler in color. At the time of Mr. Brewster's examination this was the only red example of this subspecies known.

The following account of a pet Screech Owl may be of interest to our readers. The bird.was captured after leaving its nest by a boy and brought to me alive and uninjured about June 25th, 1905. It was in the nestling or downy plumage, 
the remiges nearly fully developed, and was able to fly. It was named "Jimmie," though subsequently ascertained to be a female, and became a great pet. It was allowed the freedom of the shop and the store, and later was allowed to fly out of doors evenings. She answered my call, alighted upon my wrist to be fed, and followed me about in, the shop and out of doors. It began to moult about July 25th, and finished September 10 to 15 , renewing all feathers except those of the wings and tail, which it did not shed.

Its baby or birdling call was like the smothered mew of a kitten; this was frequently uttered as a call for food or in answer to its name, or as a call to me for notice. After completing its moult this cry was not often uttered unless she was hungry and demanding attention. A note that was uttered when excited was a short wow, wow, repeated several times, reminding me of a puppy's bark. This was uttered at times when very hungry and demanding immediate notice, and was also uttered as notice of the presence of a dog-very vehemently when a dog came into the shop. A note like $c r-r$-oo-oo$o o-o o-o o-o o$ uttered gently and so low as to be heard only a few yards away was seemingly a love note and was an affectionate greeting to me as it would be to her mate. Then another note similar, possibly the same under other conditions was like the whistling of ducks' wings in overhead flight at night.

(C. E. A.)

Otus flammeolus. Flammulated Screech Owl.

Rare. The range of this species was extended to include Colorado by Aiken on his finding the bird and eggs June 15, 1875 in Copper Gulch, in southern Fremont County. But two specimens of this rare owl are recorded from El Paso County; one in nestling plumage was caught alive about the middle of September, 1883, on Fountain Creek at the mouth of Red Rock Cañon; the other was found dead along the same stream just 
south of Colorado Springs, May 9, 1898. Both these birds were in cottonwood groves on edge of plains, but other records from the State are from the mountains from the foothills up to over 8,000 feet.

\section{Bubo virginianus pallescens. Western Horned Owl.}

Resident, common.

Horned Owls are common in El Paso County, more especially of course where there are trees, and range in the nountains as high as there is timber. It even finds its way into the city occasionally, for Lloyd Shaw saw one on North Nevada Avenue, Colorado Springs, June 1, 1911.

Nesting in hollow trees, using old Magpies' nests or buildjing their own, and on ledges or in cavities in rocks or earth banks, the eggs are laid in March and the young hatched early in April. They are rather destructive birds and apt to attack poultry, though they also kill many mice, ground squirrels and gophers. April 10, 1899, one was brought to Aiken killed on the nest, which latter contained newly hatched young, and a rabbit and quail, the latter not torn or eaten.

Mr. Waldron, living at a ranch west of Pring, had a large number of domestic pigeons, which were preyed upon by the Horned Owls. One bird got into the habit of coming every day and killing a pigeon. Its method of attack was to swoop down on the birds as they rested on the roof of the barn and frighten them into flying. Then singling out some particular bird it would pursue that until it sought safety by returning to the barn, and the owl would so time its pursuit as to seize the pigeon just as it alighted, and carry it off.

Some years ago trout breeding was carried on at Manitou Park. It was discovered that something was taking fish from one of the ponds, and after some time it was found that Horned Owls were the culprits. Posts were set about the 
pond, steel traps set on top of these, and several owls were captured. After that the fish ceased to disappear.

William Unruh, an old-timer who lived in the County nany years ago, had a curious experience with a Horned Owl about 1875. He was camped in the mountains near Colorado Springs in the winter, and lounging by his campfire in the evening he made some movements of his head which caused his heavy beard to move about, and to his great surprise a Horned Owl suddenly pounced down upon his beard and seized it. Unruh grasped the bird by its legs and killed it, and brought it to town to Aiken.

There seem to be two forms of the Horned Owls in the County, a lighter colored bird which lives and breeds on the plains, following the streams a short distance into the mountains, living in the cottonwoods, and a darker bird which lives in the heavy timber of the mountains to timberline. While the female of these riountain birds is as large as the female of the plains form, the male is proportionately much smaller.

\section{Bubo virginianus subarcticus. Arctic Horned Ow1.}

Rare winter visitor.

Four or five owls of this form have come into Aiken's hands during the past forty years. One submitted to Ridgway was referred to this subspecies.

\section{Nyctea nyctea. Snowy Owl.}

Winter visitor; rare. Two El Paso County specimens have been brought to Aiken, one killed somewhere on the Divide about $1875-77$, the other near Ramah, about 1883 . Besides these one was taken at or near Calhan in 1898, and one was described to him as killed on the Bates Ranch between March 20 and 28, 1899. Two years ago a man named Lightner spent part of the winter at the Half-Way House on the Pike's Peak Railway, and saw a Snowy Owl near there sev.. eral times, though he did not shoot it. 
Plate IX.

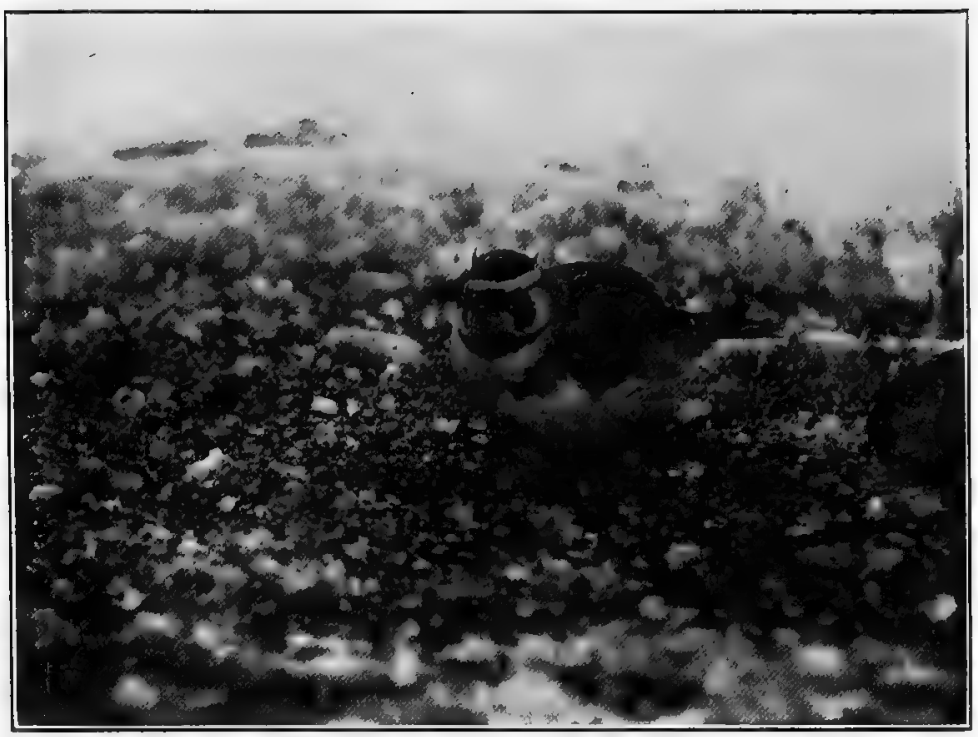

Fig. I6.

E. R. W., Photo.

A Single Bird.

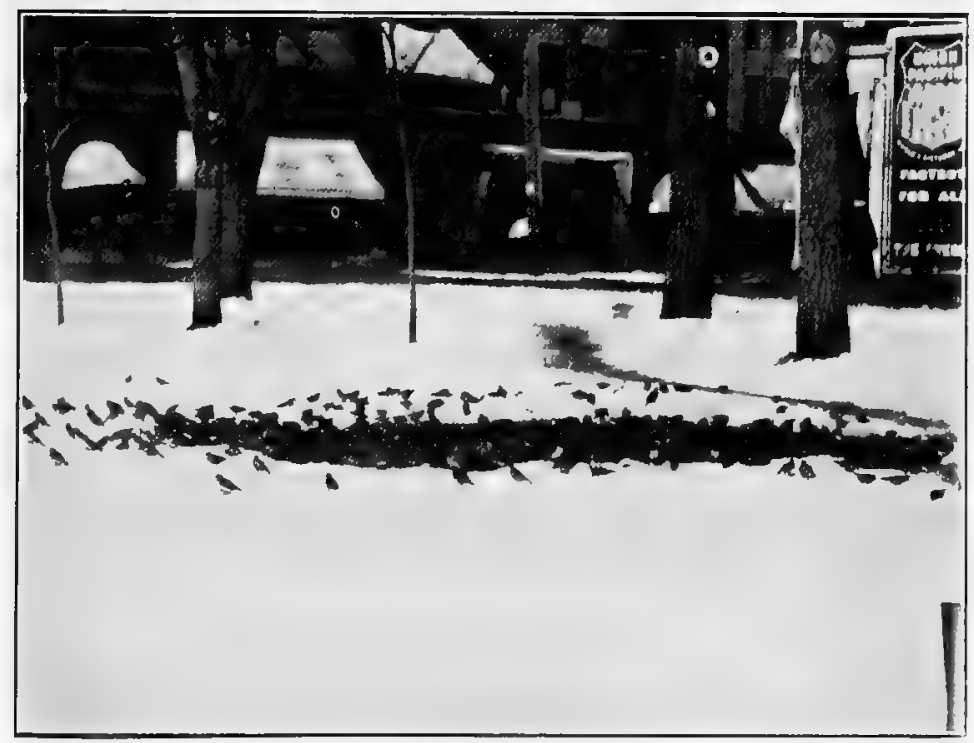

Fig. 17 .

E. R. W., Photo.

Desert HoRnen LaRK.

A Flock feeding in Alamo Park, Colorado Springs, February, 1903. 
Plate $\pi$.

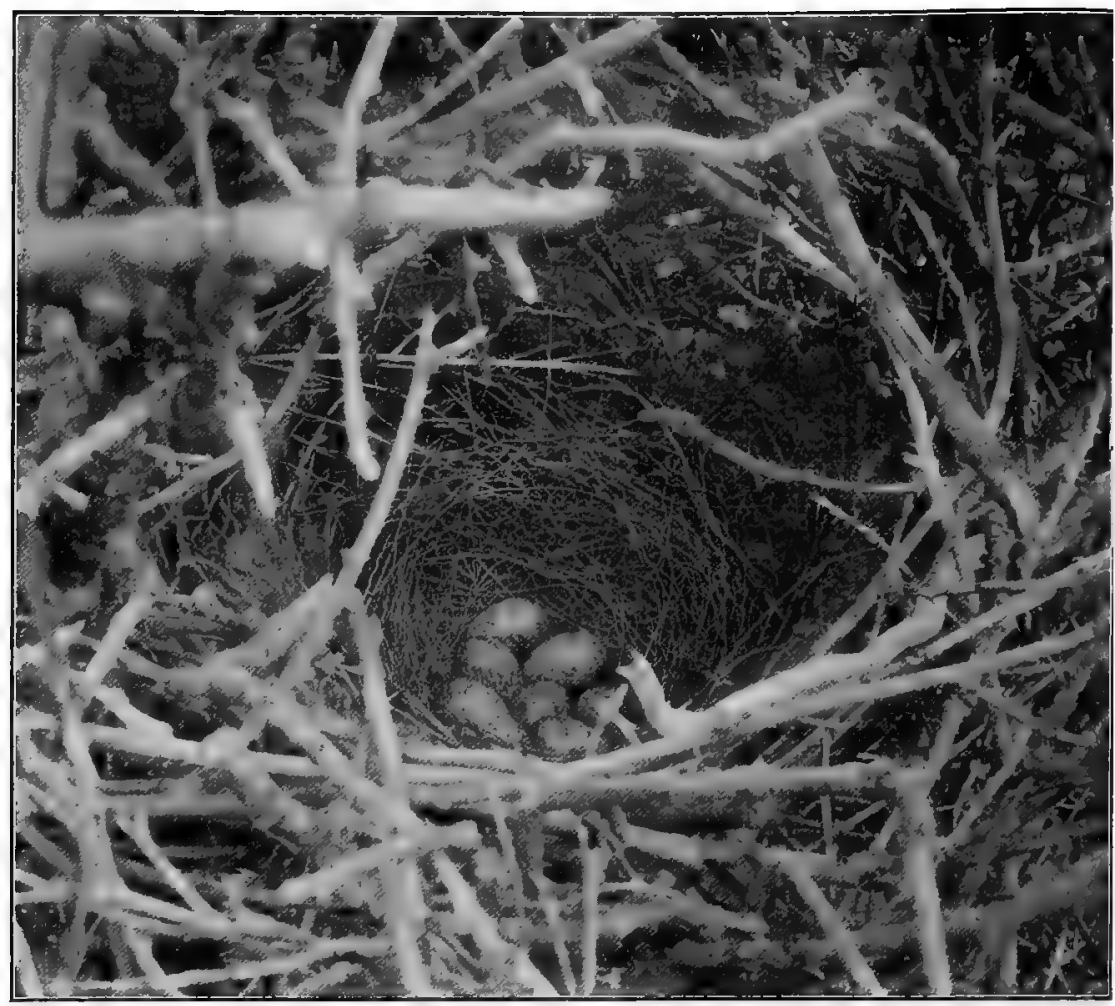

Fig. 18 .

E. R. H'., Ploto

Interior of MagPie's Nest, Showing EgGs.

Near Colorado Springs.

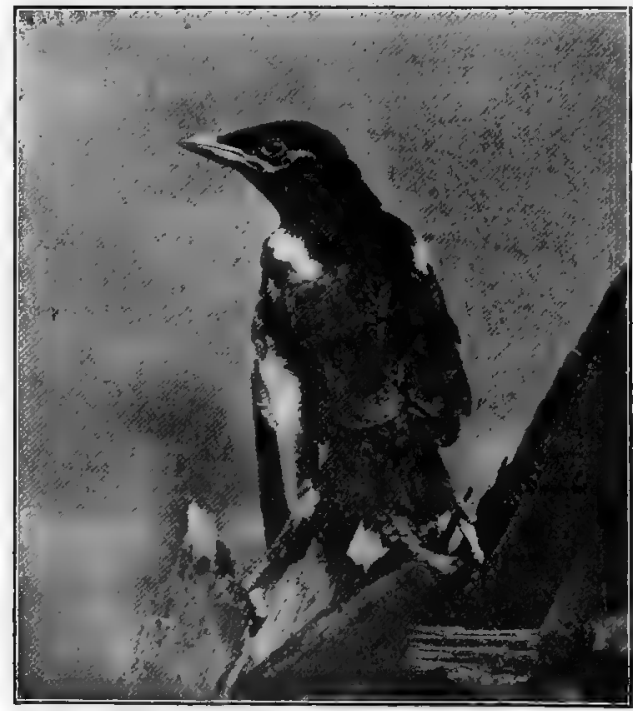

Young M.igrie Just From Nest.

E. R. H.. Photo.

Gunnison County, Colo. 
Speotyto cunicularia hypogæa. Burrowing Owl. "Prairie Dog Ow1."

Common locally about prairie dog towns. Apparently a summer resident only for it is not seen in winter, November 2,1871 , being the latest autumn date we have.

Burrowing Owls are not now as common in F.1 Paso as they were formerly; too many are killed by hunters as they cffer rather a tempting mark, and many are brought to the taxidermist to be mounted. It is a pity to slaughter the queer little fellows so uselessly and wantonly, for they are really of use when alive, feeding on mice and insects. They live in the deserted burrows of prairie dogs, laying their eggs several feet below the surface late in May.

As a table bird the Burrowing Owl is not to be recommended, Aiken says, and he should know, because he has tried it. Some years ago one was brought to be mounted on Saturday evening. The weather was warm and to keep the bird from spoiling until Monday Aiken carried it home and placed it in the family ice chest. Invited guests were present at Sunciay dinner and when all were seated at the table Aiken's sister, who it may be stated is not as good an ornithologist as her brother, remarked that she had prepared a special dish for him - "the bird you put in the ice chest." At that moment the the waitress brought in a dainty looking browned and buttered fowl which from appearance might have been a woodcock, but it wasn't. A mild outburst of indignation passed and the laugh having subsided he generously offered to share his titbit with each one present, but each as graciously declined. Aiken, however, declared he would not allow the opportunity of testing the quality of owl meat to pass, so he cut a choice bit from the breast and ate it, after which he decided to save the balance of the bird for his dog. This dog was very greedy for meat. Anything in the way of meat offered he seized voraciously and gulped down. When this bird was held 
temptingly toward him he seized it as usual but instead of swallowing it he very carefully laid it on the ground, took one cautious sniff of it and then dropped his tail and went into his kennel. No owls have been served at the Aiken table since that.

Glaucidium gnoma pinicola. Rocky Mountain Pygmy Owl.

Resident; probably more common than is generally supposed but often escapes notice from its habit of sitting quietly on a branch as a person passes by.

This little owl ranges to timberline, breeding from 8,000 feet up, having been known to nest at the Strickler Tunnel at almost 12,000 feet. It comes down to the plains in winter and at such times is not uncommon. It has been known to make its winter quarters in a barn on a ranch.

The bird seems to be of a perfectly fearless disposition, paying little heed to the presence of man, and often attacks birds larger than itself. William Unruh, in the winter of 1874-5, shot into a flock of Bohemian Waxwings on a dead pine tree and dropped several, when a Pygmy Owl which had been perching in the same tree flew down and seized one of the wounded birds as it reached the ground, and was shot by Unruh with the Waxwing in its claws.

Wallace Hook said that he was once walking through the edge of some timber in the mountains when he saw one of these owls dart after a flying Long-crested Jay, bearing it to the ground.

February 1, 1900, a Pygmy Owl was brought to Aiken which had been caught at the Garden Ranch near Colorado Springs under very peculiar circumstances. Two men were at the house on the ranch and heard the squalling of birds. They ran out to see what was going on and reaching the steep bank of the arroyo in which the creek there runs saw a Pygmy Owl and Bob-white Quail by the edge, of the water. The owl 
was on its back with the claws of both feet, clutched about the quail's neck, and the latter was futtering and struggling trying to escape. The men jumped down into the gulch and picked up both birds, the owl offering no resistance, but by this time the quail was dead.

On the same date an employe at the Giddings Ranch, 12 miles east of Colorado Springs, told Aiken that he had seen Pygmy Owls attack half grown chickens in the farm yard, the method of attack being to swoop down from a nearby tree and strike the chicken in the head, and to follow this up by repeated passes until the chicken was disabled or exhausted. These various occurrences show it to be a day owl.

In 1884, a tie chopper working somewhere in the Ute Pass, near Green Mountain Falls, cut down a hollow tree in which were four young Pygmy Owls about two-thirds grown. Ont was killed by the fall, the other three were brought alive to Aiken, who kept them alive about two weeks. These birds were nearly fully feathered. When first taken in the hand they played possum, laying perfectly motionless, and it took a little time to induce them to sit up on a perch. While they were kept they made no cry nor any attempt to use their claws or to bite, exhibiting none of the ferocity with which adult birds attack their prey.

\section{Geococcyx californianus. Road Runner. Chapparal Cock.}

Resident; rare. This odd bird is a resident the year round, most of the records coming from along the Fountain Valley. It has also been reported from the sandstone hogback just north of the mouth of Bear Creek Cañon; from near Glen Eyrie, and has been seen several times on the mesa between there and Colorado Springs. Also reported from Austin Bluffs, Fountain, Bates Ranch, Barnes's Cañon, Turkey and Rock Creeks. There is a record from Palmer Lake. Where tree cactus grows it frequents the places where it is, elsewhere its is very, apt to be found about oak brush. 
Pike mentions in his Journal a bird about the identity of which there has been a certain amount of speculation, and which Coues considered to have been the Carolina Paroquet. The bird was taken by Pike December 25th, 1806, at which date he was camped, as estimated by Coues, somewhere about the neighborhood of Brown's Cañon, 7 miles above Salida. Pike says :

"Caught a bird of a new species, having made a trap for him. This bird was of a green color, almost the size of a quail, has a small tuft on its head like a pheasant, and was of the carnivorous species; it differed from any bird we ever saw in the United States. We kept him with us in a small wicker cage, feeding him on meat, until I left the interpreter on the Arkansaw, with whom I left it. We at one time took a companion of the same species and put them in the same cage, when the first resident never ceased attacking the stranger until he killed him."

Instead of being a Paroquet it seems much more probable that this bird was a Road Runner for various reasons. The color, green, applies to that bird as well as to the other, for many of its feathers are of that color, and there is a strong greenish tinge or cast to most of its plumage; the size of the body is just about that of a quail; and the feathers of the head are erectile and make a crest or tuft quite similar to that on the head of a Ruffed Grouse, which Pike probably meant when he compared it to a pheasant, that being the name by which the grouse was and is now known at his home. The fact that they fed the bird on meat is another point in favor of its being this species, which lives almost exclusively on animal food. It also seems that a Road Runner would be more likely to be caught in any trap Pike could have made than a Paroquet; moreover, Pike must surely have known what a parrot was like, and if he had caught one would have called it such, even though he might have expressed surprise at finding it in such a locality. Then again, if a Paroquet, the first caught 
bird would hardly have been likely to have killed the other when put in its cage.

It may be objected that the altitude, above 7,000 feet, is too great for the Road Runner, but it must be remembered that there is a record of the bird on Marshall Pass, at 10,000 feet, not very many miles to the southwest, and the Arkansas Valley is here (Brown's Cañon), in spite of the altitude, a cedar and piñon region, in other words either Upper Sonoran or the very lowest portion of the Transition zone, and these zones are within the natural habitat of the bird, which is reported common fifty miles farther down the river.

To Aiken belongs the credit of having first advanced this theory as to the identity of Pike's bird, but it seems the most plausible to us both. Though somewhat beyond the limits of our paper the preceding note hardly seems out of place hert, in view of the interest which is taken in Pike's travels in Colorado.

Coccyzus americanus americanus. Yellow-billed Cuckoo.

Summer resident; rare. Arrives the middle or last of May. There is a specimen of the Yellow-billed Cuckoo in the Aiken Collection, taken at Ramah, June 4, 1898, at which place two were seen. The bird seems to be very rare in El Paso County.

Ceryle alcyon. Belted Kingfisher.

Summer resident, not uncommon. A few remain through the winter. Considering that suitable localities for them are rather scarce in El Paso County, Kingfishers are not so very rare. They are noted frequently in the upper end of Monument Valley Park, where the small ponds contain suckers and such fish. One was noted there regularly in 1912 from July 28 to Cctober 14, and in 1913 from April 10 to October 8. It was scen by Aiken during the winter of 1871-2. 
Dryobates villosus monticola. Rocky Mountain Hairy Woodpecker.

Resident through the year; common.

Breeds from the foothills up to 10,000 feet or nore, probably as high as there is suitable timber. Aiken took a nest with four eggs on Turkey Creek, May 26, 1872. Frequently seen in winter in the trees along the streams, and occasionally comes into the heart of Colorado Springs. It has been founa at Lake Moraine in January.

Dryobates pubescens homorus. Batchelder's Woodpecker. Downy Woodpecker.

Resident; common, but somewhat irregular in winter; rare in summer. No breeding records known for the County.

This small woodpecker ranges over about the same area as the preceding species, but seems more irregular in occurrence and distribution. It has been seen at Lake Moraine in December, March, and June, and at Seven Lakes in January. showing that it is in those high altitudes the year round, while at the lower elevations it has been found at all seasons.

Picoides americanus dorsalis. Alpine Three-toed Woodpecker.

Rare resident in the mountains.

There are but few records for this species in E1 Paso County. W. C. Ferrill took one at Palmer Lake, June 4, 1900. which is now in the collection of the State Historical and Natural History Society at Denver. Dr. W. W. Arnold saw a pair breeding near the Half-Way House, June, 1905. Harry Amann killed one near Victor, Teller County.

In the summer of 1912, L. L. Shaw discovered a breeding pair in Crystal Park. The nest hole was in a dead aspen tree 8 inches in diameter, and was five feet above the ground. 
There was but one young bird and that disappeared before it was ready to leave the nest, possibly captured by the Sharpshinned Hawks which had a nest not far away.

Sphyrapicus varius nuchalis. Red-naped Sapsucker.

Summer resident; common. Arrives in April. Breeds in the mountains.

Sphyrapicus thyroideus. William's Sapsucker. April.

Summer resident; rather uncommon. Arrives early in

This woodpecker is a bird of the mountains, ranging from the foothills to above 10,000 feet. Aiken took a female in downy plumage on the Cheyenne Mountain road, August 29. 1897.

Melanerpes erythrocephalus. Red-headed Woodpecker.

Summer resident; common. Arrives the middle of May, departs in October, having been seen as late as the 25th.

This species breeds over the lower portions of the County especially in the cottonwoods along the streams, not going into the mountains in the nesting season, but after that time may wander quite extensively, and a young of the year was taken at Lake Moraine, September 2, 1905.

In 1913 a pair apparently took possession of a hole in Monument Valley Park which had been made and occupied by Flickers that spring, and they were there as late as May 13, but on the 26 th the lied-heads had it. The Flickars were first seen at the hole the last of April. They could hardly have raised their young and presumably were forcibly evicted. The Red-heads were seen at the hole regularly after this into June, and on July 27 both old and young birds were seen near the nest site. 
Asyndesmus lewisi. Lewis's Woodpecker.

Resident; common in summer, only occasionally seen in winter. The spring migrants arrive the middle or latter part of April, and the birds remain until the middle of November, at least at times.

While this species, is noted above as a resident, it is much more abundant in summer than in winter, and very probably many winters none stay in the County. January 4, 1907, half a dozen or more were seen in the bluffs north of Colorado Springs, but this was a very mild winter. While it is found over most of the County where there are trees from about 8,000 feet down, yet probably in the breeding season most, if not all, are found in the yellow pines, though there are also some in the cottonwoods along the lower streams. It, however, leaves the pines to some extent when the young are fledged, and scatters over the County, and is sometimes seen in family parties on the plains at a considerable distance from the mountains. August 2 and 3, 1909, they were common in the Fountain Valley from the Pueblo County line north to Colorado Springs.

While on the Divide near Peyton in July, 1897, Aiken noted that this bird affected the tallest pine trees on the ridges and was continually taking flights from the top of one tree to another, often crossing ravines or going to a considerable distance and high in the air. They sometimes ascend vertically in the air 50 or 60 feet, perhaps to catch an insect. and then sail off to a tree top two or three hundred yards away.

Centurus carolinus. Red-bellied Woodpecker.

Rare; taken but once in El Paso County, by Aiken at Fountain, in 1873.

Colaptes cafer collaris. Red-shafted Flicker.

Resident; common.. 


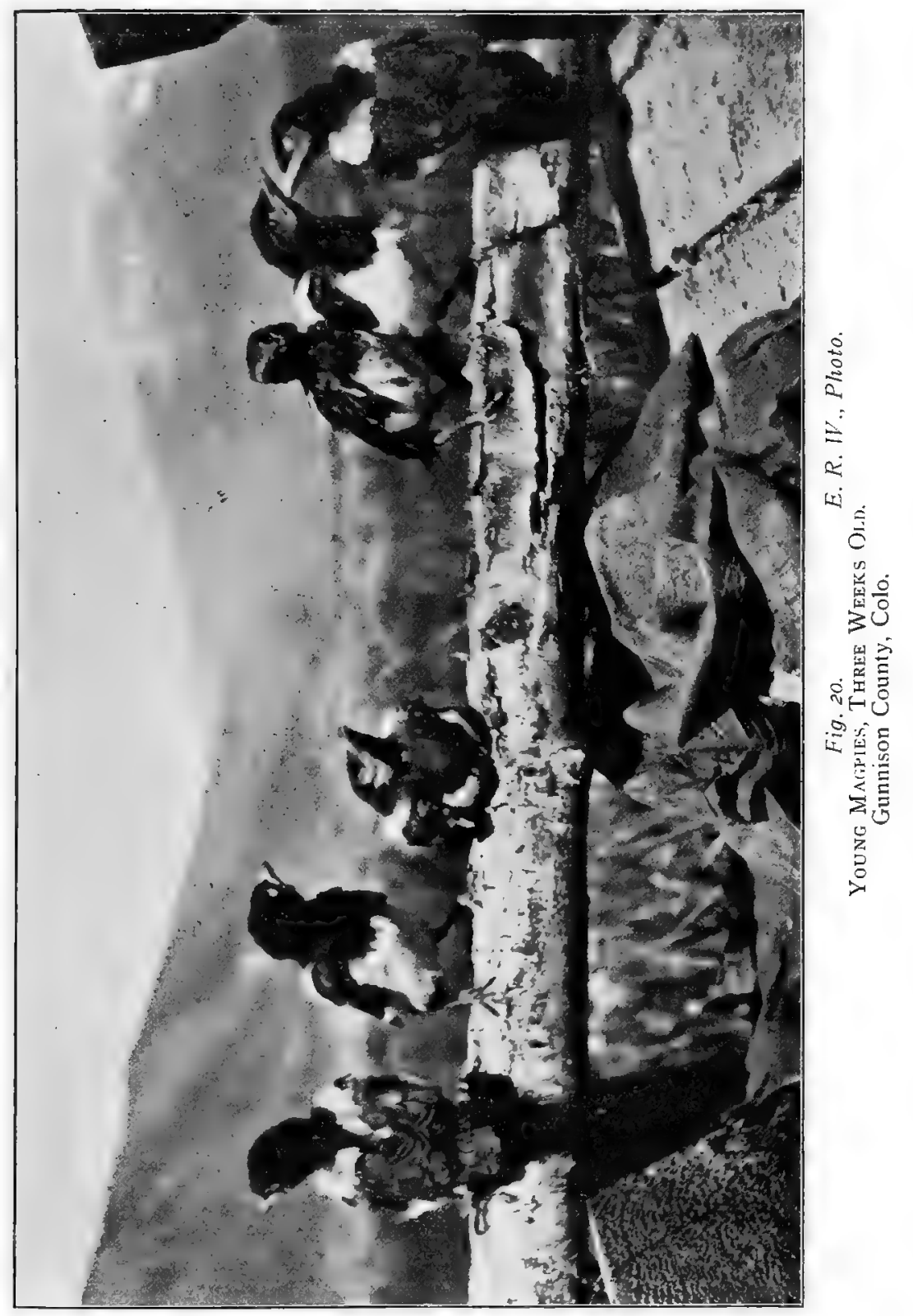


Plate XII.

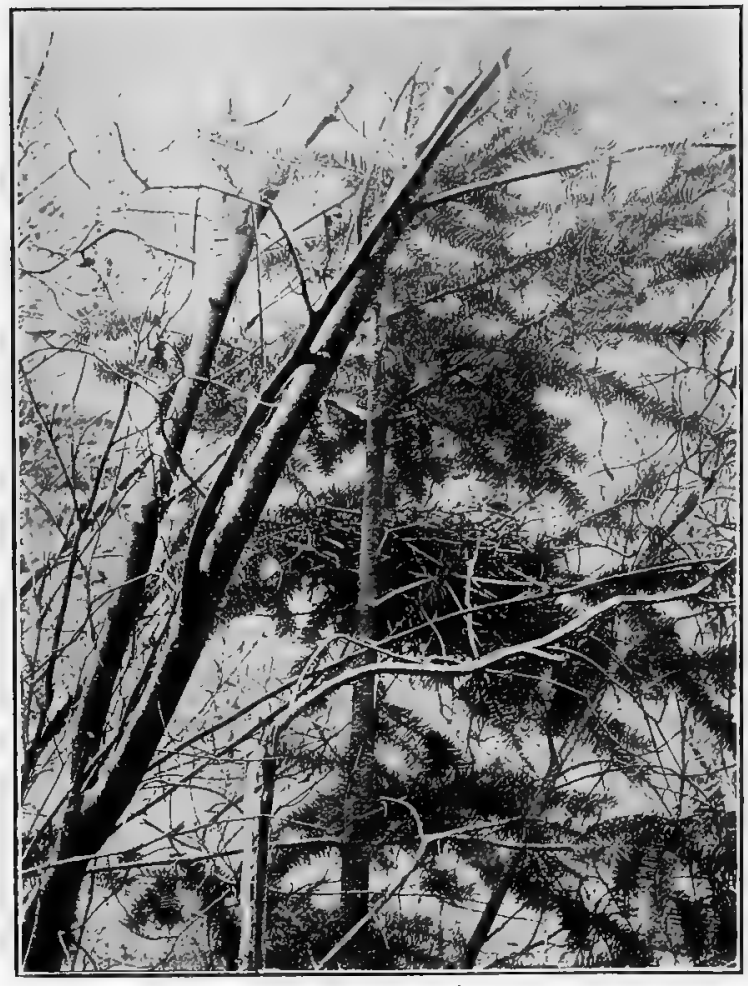

Fig. $2 I$. E. R.W., Photo.

The Nest in the Tree.

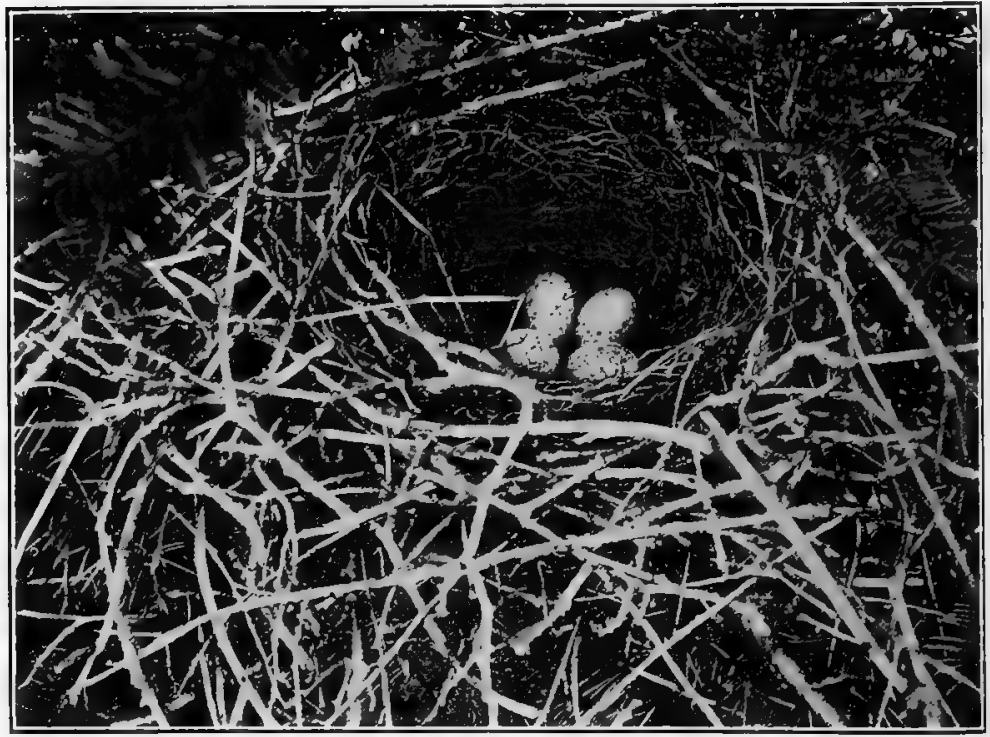

Fig. 22.

E.R. W. Photo.

Nest of Long-Crested Jay. Interior, Showing Eggs. Near Bear Creek Cañon. 
A common bird all over the County where there are trees, and ranging to timberline in the mountains, breeding throughout its range. Often seen in Colorado Springs through the year, in the summer devouring the ants on the lawns and gravel walks, and gathering grubs and insects. There are always some to be found in Monument Valley Park. As noted under the Red-headed Woodpecker a pair of Flickers had a nest there April 28, 1913, and were driven out by the other species. September tenth following a female Flicker was observed feeding young at this hole. A decidedly late date for a brood of this species to be coming out and it would be very interesting if one knew that it was the same pair which were ousted from that nest in May.

The majority of winter residents probably come from the far north, but it is certain that some individuals remain throughout the year. Dr. Arnold has fed the same pair throughout the year. Some of these winter birds have a well- marked red nape, and there is a series of specimens in Aiken's private collection which show every gradation from a mere indication of red on the nape up to a strong nuchal band a quarter of an inch or more wide. It would seem possible that these birds represent a distinct race.

They are distinct from the so-called "Hybrid Flickers," which are rarely seen either in winter or during the breeding season, but which are fairly common in migration, beginning to come in March, but rare in April ; they return in September and October. These birds have the body coloration of collaris, and the red mustache, with the undersides of the wings and tail yellow or saffron. It is not uncommon to find breeding birds with a few yellow feathers in wing or tail. May 15, 1904, Aiken found at Ramah a Flicker's nest with seven fresh eggs, capturing the male bird on the nest. This bird had the underparts of the wing and tail bright salmon-colored. Some of our breeders with all red show a strong vinaceous 
tinge on the breast, a tendency toward the northwest coast form saturatior.

The holes are usually excavated in dead wood, at almost any height from five to fifty feet or more from the ground.

O'Connor killed three Flickers with black cheek marks and yellow shafts about May 1, 1911, ten miles east of Fountain.

\section{Phalænoptilus nuttalli nuttalli. Poor-will.}

Summer resident; common. Arrives usually early in May, the earliest date being April 27, 1899, and departs late ii September or early in October, having been noted on $\mathrm{Oc}-$ tober 4th, 1904.

This species seems to be largely or entirely a bird of the foothills, and apparently at times ranges quite high, for Warren found young in the Sangre de Christo mountains, July 11,1909 , at an elevation of above 10,000 feet. It spends the day on the ground on the brush covered hillsides, flying out into the open spaces at dusk to hunt insects.

Chordeiles virginianus henryi. Western Nighthawk. "Bull Bat."

Summer resident; common. Arrives about May 23, departs usually by September 25 .

The Nighthawk is common on the plains and the higher open ground, its habits being similar to those of the eastern bird, spending the day on the ground, on top of a post, or perched lengthwise on a limb or fence rail: The eggs, usually two, sometimes only one, are laid on the bare ground without the slightest semblance of a nest.

August 2, 1909, what appeared to be a migratory movement of Nighthawks was seen a few miles south of Buttes station; altogether from 50 to 100 of the birds were seen, all flying southerly in a leisurely manner and not hunting insects. 
They were not in a flock, but came along in a scattering fashion, by ones, twos, threes or more.

August 4, 11 and 18, 1912, a Nighthawk was seen in Monument Valley Park, always on the same place on a certain limb or a cottonwood, presumably its regular roost during the day. The tree was on the bank of the creek, and not far from a walk which was quite constantly used. June 2 , 1913, a Nighthawk was seen on the same high limb, probably the same bird returned for the summer. Because of absence from home no further observations were made until late in July, when nothing was seen of the bird, but during the summer men were working on the creek bank close by and no doubt disturbed the bird so that it abandoned the place.

Aëronautes melanoleucus. White-throated Swift.

Summer resident; locally common. Begin to come the last of March, Brewster and Allen having noted it March 24, 1882, but probably the main body comes early in April. Departs the middle or latter part of September, the 18th of that month being the latest date we have.

"Observed only at the Garden of the Gods, where many pairs were breeding, though sought for at Castle Rocks and other similar places. They breed in holes and crevices in the rocks, usually far above gunshot. They seemed very shy. and flew mostly near the tops of the highest rocks. Upon ascending the rocks most frequented by them they moved to other points, and thus managed to keep generally out of range. By spending a considerable part of two days, we procured only four specimens, though several others were killed, which fell in inaccessible places. They fly with great velocity and are very tenacious of life. As they swoop down to enter their nests, the rushing sound produced by their wings can be heard to a considerable distance. Hirundo thallassina (i.e. T. t. lepida) was also breeding here in similar situations." Allen, 1872. 
The preceding description of the habits of this bird holds good today. It is, as would be inferred from this, a lover of cliffs and cañons, where it nests and raises its young in the most inaccessible places. Besides the Garden of the Gods, it is found about the Cheyenne Cañons, Bear Creek Cañon, and Sclater records it from Glen Eyrie. Lloyd Sliaw noted it in Ute Pass and at the "Gateway Rocks" at Crystal Park, though not breeding there. June 5, 1909, the prescnt authors saw tw or three near the Glen Cairn Ranch on Turkey Creek. Several were seen about the reservoir in Monument Valley Park, May 18, 1913. In May, 1908, Aiken observed a colony about two miles east from Palner Lake, on the crest of the Divide, and saw some near St. Peter's Dome, in July, 1907.

\section{A.rchilochus al xandri. Black-chinned Hummingbird.}

Rare.

This species has previous to this only been recorded from the southwestern part of the State; however, Aiken saw a male hummingbird a short distance south of Colorado Springs May 17, 1898, which he believes was the Black-chinned. He also saw a female or immature hummingbird in Monument Valley Park' August 18, 1907, which from the oscillating tail movement charactertistic* of this species he believes to have been the same. In July, 1906, a visiting lady bird student informed him that while sitting near the top of the Seven Falls in South Cheyenne Cañon a male hummer poised close before her which she positively identified as the Black-chinned.

*Aiken had exceptional opportunities of studying the characteristics of the four hummingbirds listed in the present paper while collecting in the White Mountains of Arizona in the summer of 1876 . where all of them were plentiful. Following is an extract from his field notes: ${ }^{\prime} R$ ufus most abundant species in August, frequenting open woods where extensive beds of scarlet pentstemon (Pentstemon torreyi) grow. Moutls forepart of August without becoming ragged. Habit in common with blatycercus of chasing others of species. These demonstrations accompanied by chippering notes, very loud for such small birds. Noise made by wings of rufus is a loud sharp hum approaching that made by platycercus, which is a whizzing noise that may be heard at a 
Selasphorus platycercus. Broad-tailed Hummingbird.

Summer resident; common. Begins to arrive the first week in May. Departs in mid-September, the latest date we have being September 18, 1913.

This species is found all over the County, ranging well up into the mountains, being known to attain an altitude of above 10,000 feet, and breeding wherever found. In summer it often comes about the gardens in Colorado Springs, seeking its food from the flowers, and sometimes, when the leaves have fallen, and the birds have retired to their winter quarters, the delicate little nest will be noted on a shade tree by the street. One confiding bird built its nest on the electric light fixture directly before the front door of a house, on a porch where people were continually going and coming, and raised two young.

Selasphorus rufus. Rufus Hummingbird.

Summer resident; rare.

Aiken found this species on the Divide near Peyton in July, 1897, and noted one in Colorado Springs, August 21, 1898, and saw one near the mouth of Bear Creek, August 20. 1907.

One spring some fifteen years ago the mummified remains of a young Rufous llummer were found in a barn at Manitou hanging to a piece of baling wire by the feet. It was supposed the bird went into the barn the autumn before, for

distance of from 60 to 100 yards. Alexandri is less active, less aggressive. Noise by wings a plain hum. Female similar to female of platycercus but readily distinguished when hovering before a flower by the oscillating (up and down or backward and forward) movement of the spread tail. The other species carry the tail still. Calliope frequents same localities as the others but prefers different flowers. Keeps low in and among the plants where it easily escapes notice. Noise made by wings is a low hum like that of a large bumblebee. All four species have the common habit of alighting among trees, usially on a dead twig of a lower branch. They are very cute about hiding. 
refuge from a cold storm, and perished from the cold, possibly freezing, and either thawed and dried out very gradually, or else that the toes were so much contracted that the fuet did not lose their hold on the wire when the bird died.

\section{Stellula calliope. Calliope Hummingbird.}

Rare; but one record for the County, which was also the first for Colorado of the species. This was an adult male which was found dead in Cheyenne Cañon, July 25, 1897, by a Mrs. Martin, who brought it to Aiken. It was made into a skin and taken away by the finder.

\section{Tyrannus tyrannus. Kingbird.}

Summer resident; common. Arrives from the 5th to the 13th of May, and departs about September 7.

The Kingbird is common in the region in the summer, in the lower portions, ranging up onto the Divide. Its favorite breeding places are in the cottonwoods and other trees along the watercourses, and on the plains it nests wherever it can find suitable places. Keyser found a nest near Ramah containing four eggs, in the same tree with the nest of an Arkansas Kingbird and a Mourning Dove. $\mathrm{He}$ also found other nests about a mile away. Between Pueblo and Colorado Springs, August 2 and 3, 1909, it was seen frequently, but was not as common as the Arkansas Kingbird. The young are flying about the first week in July.

One August day an old bird was seen to feed its young grasshoppers in a Colorado Springs street, catching the insects on the ground in a vacant lot where they were plenty, and carrying them into the tree where the youngster was perched, beating them there on the branches, and then giving them to its baby.

At Ramah Aiken witnessed the attack of some Kingbirds on a Swainson's Hawk, which is described in his notes as 
follows: "The hawk, which was sailing about the valley and screaming scre-e at intervals, came toward the line of trees fringing the creek, when three or four Kingbirds advanced to meet it. One of them flying down upon it from above alighted upon the hawk's head, and seizing the fathers of the forehead in its beak, straightened itself and pulled vigorously, and in this attitude was carried 40 or 50 yards through the air. The hawk made no effort to dislodge the Kingbird, neither did it. show particular anyoyance, though it turned presently and retreated in the direction from which it had come."

\section{Tyrannus verticalis. Arkansas Kingbird.}

Common summer resident. Arrives and departs at about the same time as the preceding species.

The Arkansas Kingbird is the most common of the three species found in the County and is found through much of the territory treated in this list. Between Pueblo and Colorado Springs, August 2 and 3, 1909, it was very common, and family groups were frequently seen. In 1898, Aiken found breeding near Ramah, in a quite limited area, about fifty pairs of Arkansas Kingbirds, and only about eight pairs of Cassin's. As noted under $T$. tyrannus Keyser found it breeding near Ramah, and a nest he found contained three young and one egg. Aiken found a nest there with eggs June 5, 1898, also a number of freshly built nests which did not yet contain eggs, showing that the nesting season was hardly in full swing. This species is not altogether dependent upon trees for nesting sites, for nests have been found in cavities in stream banks,' between two fence posts, and under the rafters of a log cabin; possibly the other species may use similar sites, but we have not happened to notice such. In July, 1907, Aiken saw a nest of this species upon the crossbar of a telegraph pole at the Buttes station of the Santa Fe R. R., and the agent told him the birds had nested on the same pole the previous year; he said they were a great protection to his poultry, attacking and driving away every hawk which came in sight. 
Tyrannus vociferans. Cassin's Kingbird.

Summer resident; not common. Arrives and departs at about the same times as the two preceding species.

Cassin's Kingbird is not nearly as common as the preceding species, being the least common of our three Kingbirds, and thus its distribution through the County is not quite so well known, though it inhabits the same localities. Its comparative abundance with the Arkansas at Ramah has already been mentioned under that species. Lloyd Shaw noted a pair breeding near Prospect Lakè, June 1, 1911.

Aiken's notes compare the habits of this and the preceding species as follows:

"Although the two species resemble one another so closely in appearance there is much difference in the manners and actions of the Cassin's and Arkansas Kingbirds. The Arkansas Kingbird comes out to meet the intruder and hovers about in the air, chattering continually; they hover about the top of a tree and alight upon the topmost twigs. Cassin's Kingbird is more sedate, less active, and less noisy, and has less of the fluttering motions. It alights usually upon the side branch of a tree or in the body of it, and often sits quietly, though usually their call note, cu-ver-o, is uttered at intervals of four or five seconds in a harsh tone."

\section{Myiarchus cinerascens. Ash-throated Flycatcher.}

The only record we have of this species for El Paso County is a specimen taken by Aiken May 21, 1872, near ${ }^{*}$ Red Creek Cañon, close to the Fremont County line, several other being seen at that same time. It frequents piñon and cedar regions, and probably is not uncommon in that portion of the Countv as a summer resident. One was seen by Warren June 6, 1909 . ar Glendale, in Fremont County, but only a few miles southwest of the above-mentioned locality. 


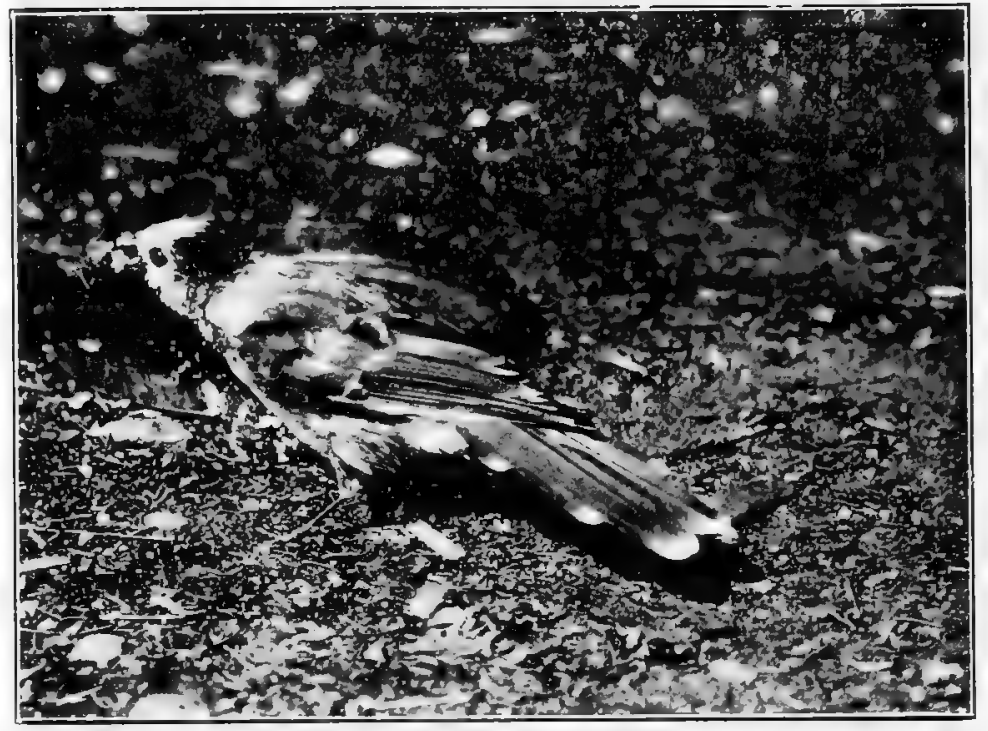

Fig. 23.

E. R. W., Photo.

Rocky MOUntaln Jay OR CAMp Bird.

Gunnison County, Colo.

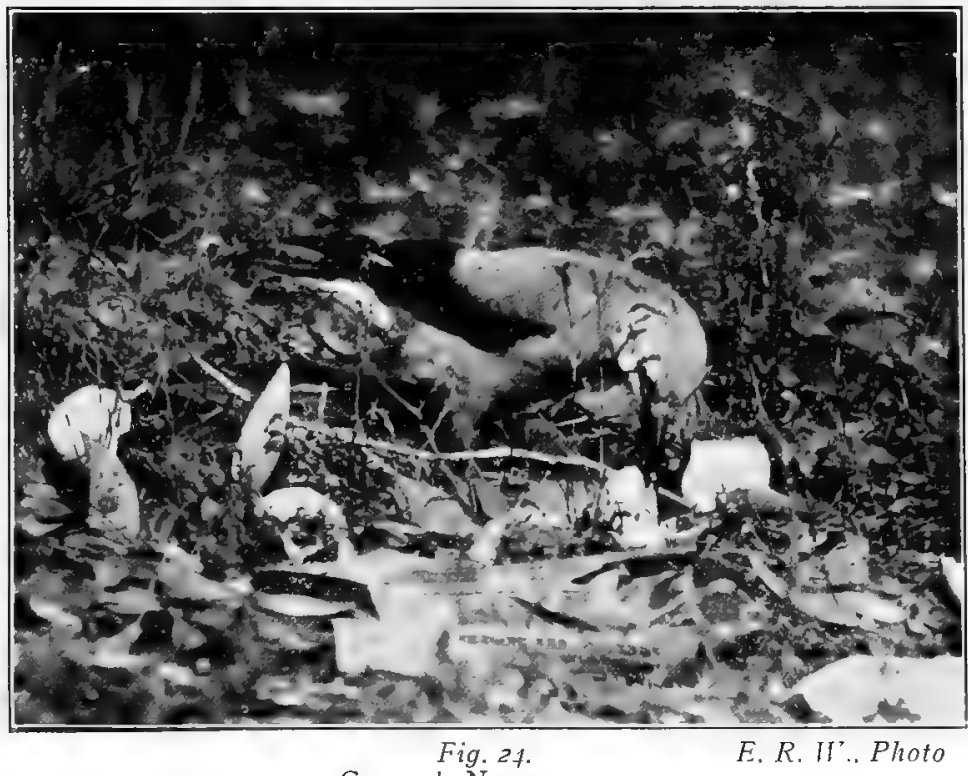

Clarke's Nutcracker.

Gunnison County, Colo. 


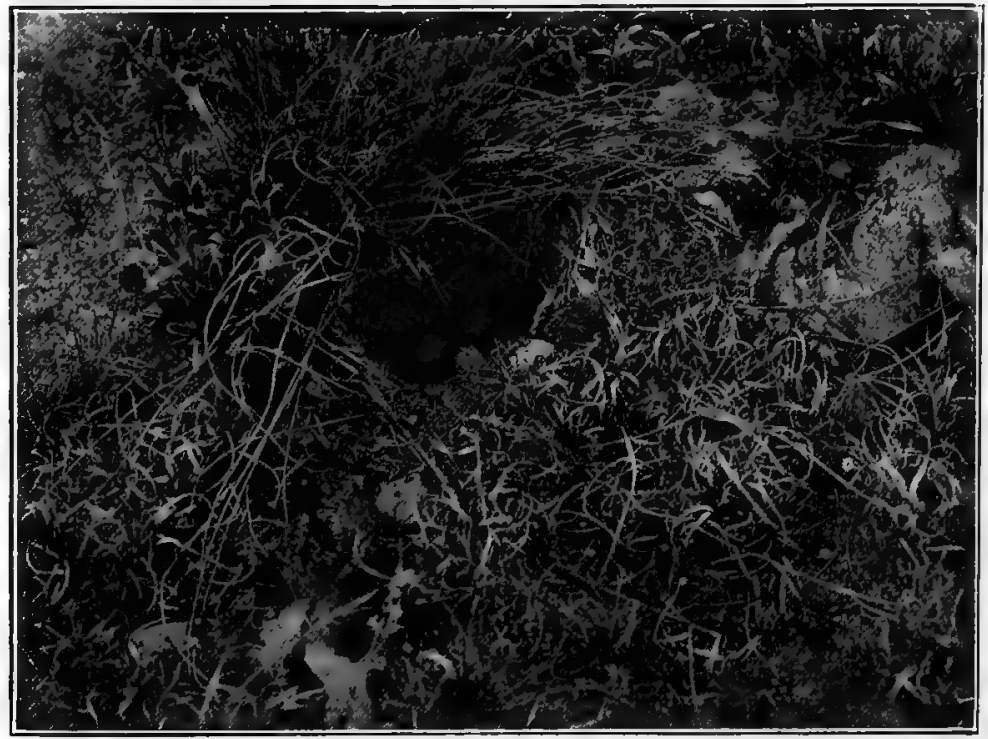

Fig. 25.

E. R.W., Photo.

Nest and Eggs of Desert Horned Lark. Near Colorado Springs.

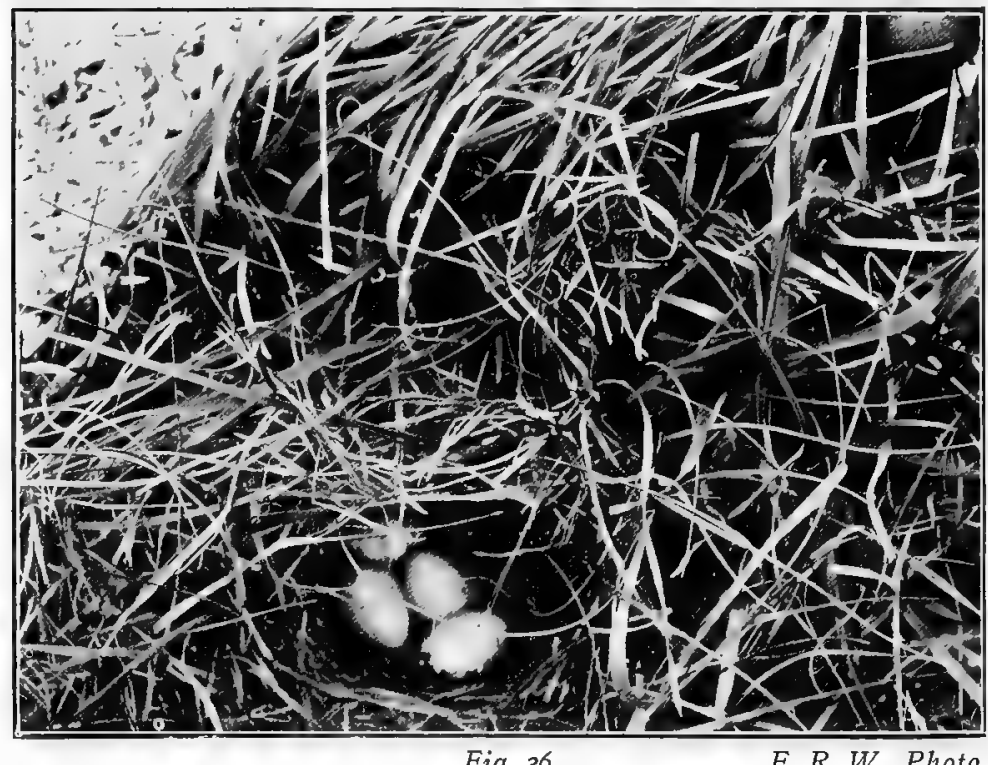

Nest and Eggs of Western Meadowlark. Weld County, Colo. 
Sayomis sayus. Say's Phœbe.

Summer resident; common. Arrives about April first, and departs the last week in September. The earliest date of arrival being March 15, 1914, and the latest date at which it has been noted being September 28, 1913.

Say's Phobe is a common summer resident in the County, ranging quite high at times, having been seen at Lake Moraine, September 2, 1905, and June 17, 1900, found breeding at Divide station, Teller County, 9,200 feet. Its breeding habits are quite similar to those of the Eastern Phobe, for it likes to nest on the sills and joists of buildings about ranches and farms, under bridges and similar locations, in cavities in stream banks, under rock ledges, and even down in wells in the stone curbing.

June 21,1905 , three young, able to fly, were seen with their parents about a house, and the old birds were feeding them. That their appetites were good was shown by their swallowing Pyrameis butterflies whole. They are indefatigable insect catchers, and continually in pursuit of prey, and the number of insects annually consumed by one must be enormous. It has the habit of perching on trees, posts, fences, or tall weeds, and continually uttering its calls, something like that of the Eastern Phobe.

Nuttallornis borealis. Olive-sided Flycatcher.

Summer resident in the mountains; not uncommon. Arrives May 20-25.

A large, rather heavily built flycatcher, with large bill, easily recognized in its summer home by its habit of perching on the topmost branches of dead trees, whence it makes its flights in pursuit of insect prey. It breeds exclusively in the mountains, going nearly to timberline. July 4, 1907, Aiken found five or six pairs breeding on the hillside below St. Peter's Dome station. It was common in Crystal Park, August 
first, 1912. Several were seen about Monument Valley Park May 26 and 27, 1913; this was of course just after their arrival in the spring.

Myiochanes richardsoni richardsoni. Western Wood Peewee.

Summer resident; common. Arrives about May 20, departs the last of September.

Found practically all over the County wherever trees can be fotind, whether on the plains or in the mountains. It was common on the Divide north of Peyton July 17, 1897, 15 being seen then. Aiken noted them singing as late as August 25, the song being zee-a, uttered in an explosive manner.

Empidonax difficilis difficilis. Western Flycatcher.

Summer resident; not common.

Most common in the mountains, and it is rarely found along the Fountain during the spring migration. Its habits are similar to those of other flycatchers of the genus. Noted on the Divide north of Peyton, August 28, 1907.

Empidonax trailli trailli. Traill's Flycatcher.

Summer resident; common. Arrives about May 25.

Common almost everywhere in the County, up to nearly 9,000 feet. Seems to prefer the neighborhood of the alders along the creeks.

Empidonax minimus. Least Flycatcher.

Rare migrant; arrives in May.

This widely distributed Eastern species reaches the western limit of it range at the eastern base of the Rocky mountains. It was first taken in Colorado by Aiken on Turkey Creek, May, 1873, and in recent years he has found it several times along Fountain Creek between the towns of Fountain 
and Colorado Springs (May 13 to June 6), and at several points along the line of the Rock Island Railroad eastward. Warren has noted one in Monument Valley Park. The earliest dates of arrival are those of Allen and Brewster, who have recorded two specimens taken May 4 and 9, respectively, during their visit to Colorado Springs in 1882.

The Least Flycatcher may be looked for among the scattered cottonwoods that fringe the streams issuing from the foothills, or which mark the occasional waterholes on the plains eastward toward the Kansas state line. It has not been found in the mountains and is not known to breed south of Wyoming. A specimen taken by Aiken in the pine belt on the Divide north of Peyton August 28, 1907: is the first record of its capture at so high an altitude as 7,000 feet or among conifers; also the only autumnal record

\section{Empidonax hammondi. Hammond's Flycatcher.}

Summer resident; rare. Arrives in May.

The eastern range of Hammond's Flycatcher meets the western range of the Least Flycatcher along the eastern base of the mountains, and except in favored localities it is scarcely more common. A specimen taken by Aiken May 20, 1908, at Butte Station on Fountain Creek is the most eastern reported in the County. The distance from the foothills is about 12 miles. Aiken met with it several times in the early seventies along Turkey Creek within the foothills, but it was somewhat more common on Beaver Creek, which runs through a narrow valley between piñon clad hills in 'Fremont County just west of our County line. Allen and Brewster took it in 1882. All migrants pass further north or retire to higher elevations to breed.

Our opportunities for observation in the mountains have not been extended enough to enable us to speak with much assurance as to its nesting within the County, but we have no 
doubt it does, Aiken found a small Empidenax in a willow thicket on the south slope of Pikes Peak, July 9-10, 1899, believed to be of this species, which, however, he failed to secure.

\section{Empidonax wrighti. Wright's Flycatcher.}

Summer resident; rather common in migration. Arrives in May and has been taken as early as the sixth (1899).

This species breeds in the mountains, probably to or nearly to timberline. The nest, as found by Warren in Gunnison County, is a cup-shaped structure made largely from the shredded inner bark from dead aspens built in the crotch of a willow. The eggs are usually four in number and pure white

Empidonax griseus. Gray Flycatcher.

A single record for El Paso County, a bird taken by Aiken at Fountain, May 3, 1872.

Otocoris alpestris leucolæma. Desert Horned Lark.

A common resident.

The Horned Larks are found on the plains and in the open country west from Green Mountain Falls. In other parts of the State they are also found above timberline in summer, breeding there, but we do not have any records of this sort for El Paso County. While the birds are residents, it is most likely that their numbers are augmented in winter by migrants from farther north, and quite possible that some of our summer residents may go south. Beginning to breed, as it does, in early April, it raises at least two broods in a season, and young have been seen being fed by their parents the last of June. A nest with three eggs was found near Colorado Springs May 14, 1903; the parent was incubating then. This nest was, as always with this species, on the ground, almost flush with the surface, and sheltered by a tuft of grass. Allen and Brewster mention a nest with two fresh eggs April 1, 1882, and full-fledged young seen April 22 and later. September 8, 1904, 
a young lark was seen which could not have been long out of the nest.

While the larks usually remain on the plains during the winter and are not especially conspicuous by their numbers, yet when severe weather comes, especially if it is accompanied by snow which lays some length of time without melting, making it difficult for the birds to obtain food, they will come into town, sometimes by thousands. This has been the case in several different winters. The winter of 1902-3 was quite a notable instance of the sort. It was a very cold winter, with snow on the ground much of the time, and consequently the larks could find little or no food on the plains, being unable to reach the ground under the snow. This being the case, they were in Colorado Springs in great numbers. The people were feeding them in many places, putting out millet and similar food for them. One fecding place was near the County Courthouse in Alamo Park. A space 8 by 12 feet would be covered by the birds feeding, and also at other feeding places they would alight so thickly as to hide the ground. February was the most severe month; after March first the weather moderated and the birds began to disappear from the town. May 14, 1912, during a cold storm with snow, Horned Larks were ciriven into Colorado Springs as far south as Weber and Columbia Streets. For some reason none came into the town in February, 1913, though there was snow on the ground for several days.

During these cold winters there is great mortality among these birds, many perishing from cold or hunger. Many are found dead under wire fences, and it would seem possible that the birds light on the wires with their feet wet from being in the snow, and the toes freezing to the wires the birds cannot get away and so freeze to death there, and afterward fall. to the ground when the feet relax their hold from thawing.

Taking advantage of the opportunity afforded by the finding of large numbers of Horned Larks dead at times of storms 
Aiken has carefully examined large series of such birds to observe the range of individual variation and to discover if extralimital forms occur. January 30, 1898, with 120 specimens in hand he writes: "I detect only one form, leucolcema, and the differences are doubtless due to age and individual variation. The majority of males measure 7.25 inches in length, wing 4.23. The brightest colored are nearly as bright as breeding birds and are assumed to be oldest, though some with pale throats appear full adults. The yellowest throated birds have this color suffusing the entire chin, throat, and sides of neck, and tinging the frontal and superciliary stripes. No males are found with immaculate white throats, but many have a narrow whitish streak from chin to breastcollar.

Streaked upper parts are taken to characterize immaturity, but some marked thus have yellow throats and some with paler backs have pale throats. It appears, therefore, that intensity of yellow is not due to age, but to individual variation. The same variation exists among breeding birds. An undoubted immature plumage is seen with duller pinkish colors and uncleveloped black loral and breast markings like females.

Females average considerably smaller. The brightest have the yellow suffusion nearly as intense as in the brightest males, but many females have white throats with no trace of yellow."

Aiken has also ascertained that breeding birds at high altitudes in the mountains do not differ from those breeding on the lower plains. Only one specimen has been detected that approaches the Mississippi Valley form; this has been pronounced by Mr. Oberholser as intermediate between leucolæma and praticola.

Pica pica hudsonia. Magpie.

Resident; common. 
The Magpie is possibly the most noticeable bird, at least to strangers, in the whole Pikes Peak region. With its conspicuous black and white plumage and long tail it at once attracts the attention of the tenderfoot, and the old-timer generally notices one when it appears. Found wherever there are trees, it lives along the watercourses and through the mountains, though avoiding the dense evergreen timber, and probably not breeding much above 9,000 feet, but it is reported to occasionally visit the summit of Pikes Peak in summer.

The bulky nests are built in almost any sort of tree. though deciduous growth seems to be preferred, but conifierous trees are occasionally used. They are placed anywhere from 3 to 50 or more feet above the ground, and we find them in the willows along the streams, in the scrub oaks of the foothills, and up toward the tops of the tall cottonwoods. The nests are quite remarkable structures; built with a foundation of twigs in which is a deep cup of mud lined with fine roots and similar material, and over all is a dome or roof of twigs and small branches, with the entrance hole in one side, just above the edge of the cup. In this are laid the eggs, as many as thirteen having been found in one nest in Montana; from six to eight is the usual number. The eggs are laid, in the vicinity of Colorado Springs, the latter part of 1 pril, five were found April 24, 1913, and there are other equally early dates, while fresh eggs are likely to be found all through May. The following dates give an idea of the laying season: May 3, 1904, a nest with one egg was found, and when next visited, the 16th, there were 8; May 10, 1904, several eggs were found in a nest so situated it was difficult to count them; May 11, 1904, nest with 2 eggs; April 25, 1910, 5 eggs; April 24, 1898, 4 eggs. The young come out of the nest about a month after hatching, but can fly only a little then or not at all, and merely hop around in the branches of the home tree or bush, and are cared for by the parents for two or three weeks longer, perhaps more. Shaw found a nest with 4 young about 3 weeks old, June 25, 1912, in Crystal Park, at 8,500 feet. 
After the breeding season is over and the young can fly well the Magpies scatter about everywhere, and especially in winter are they widely distributed seeking food. They are seen at Lake Moraine all through the winter, though they do not appear to breed there, as no nests were noted in that vicinity. In the fall there also seems to be a southward migratory movement of the species, as they are seen in large numbers along the Fountain Valley moving in a southerly direction.

One day late in September, 1913, three or four Magpies were seen near Monument Valley Park mobbing a couple of Sharp-shinned Hawks, flying at them and annoying them in every way possible.

\section{Cyanocitta cristata. Blue Jay.}

An accidental visitor, only one instance being known of its occurrence in El Paso County, a bird seen in Colorado Springs October 5, 1902, by E. P. Scheutze. Aiken took one May 27, 1905 near Limon, about 20 miles northeasterly from the northeast corner of the County. Blue Jays are abundant iil western Kansas almost to the Colorado line, and also at Wray, in northeastern Colorado, and with the settlement of the intervening region an overflow through our State within a few years may be looked for. Aiken found them at Goodland, Kansas, and over the country east of there in May, 1899. They were observed in flocks flying from one tree claim to another, which were in most cases several miles apart.

Cyanocitta stelleri diademata. Long-crested Jay.

Common resident in the foothills and mountains and on the Divide.

The Long-crested Jay, or "Blue Jay," as it is usually commonly called about here, is nearly as familiar a bird about the foothills and cañons as the Magpie, as it flits among the trees and bushes, sociable but shy, and it calls forth many exclamations of admiration from the tourists because of its 
Piate XV.

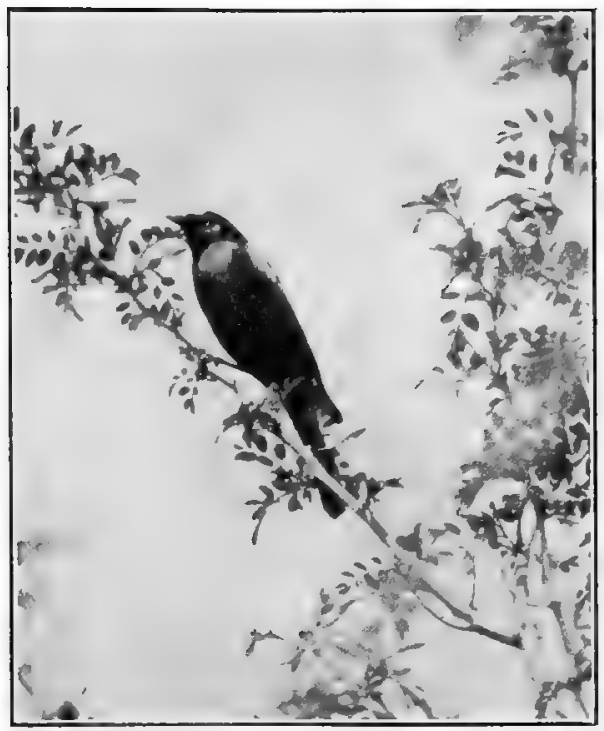

Fig. 27.

E. R. W'. Photo.

Male BreWer's Blackitrd.

Colorado Springs.

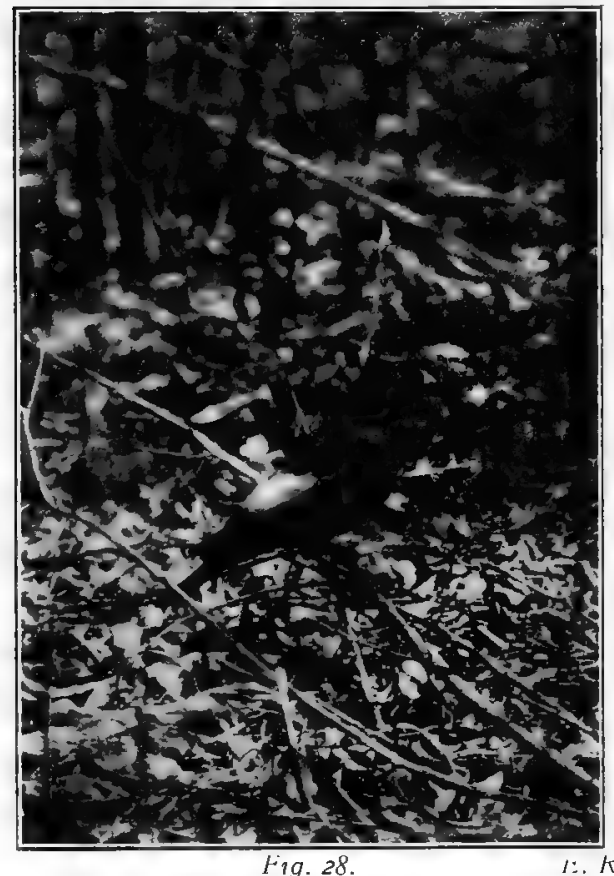

Westerv Erening Grosbeak.

Colorado Springs. 
Plate XVI.

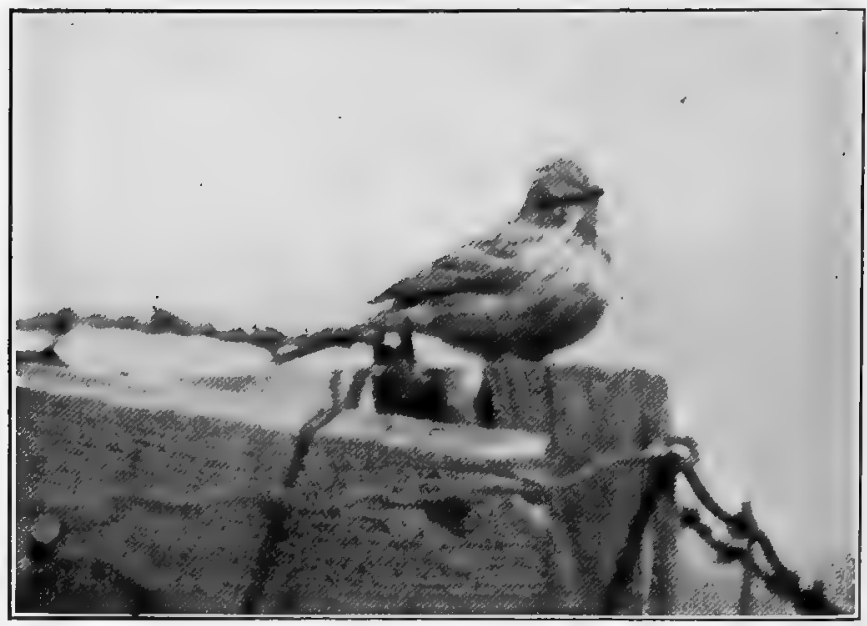

Fig. 29.

E. R. W., Fhoto.

Western Vesper Sparrow. Colorado Springs.

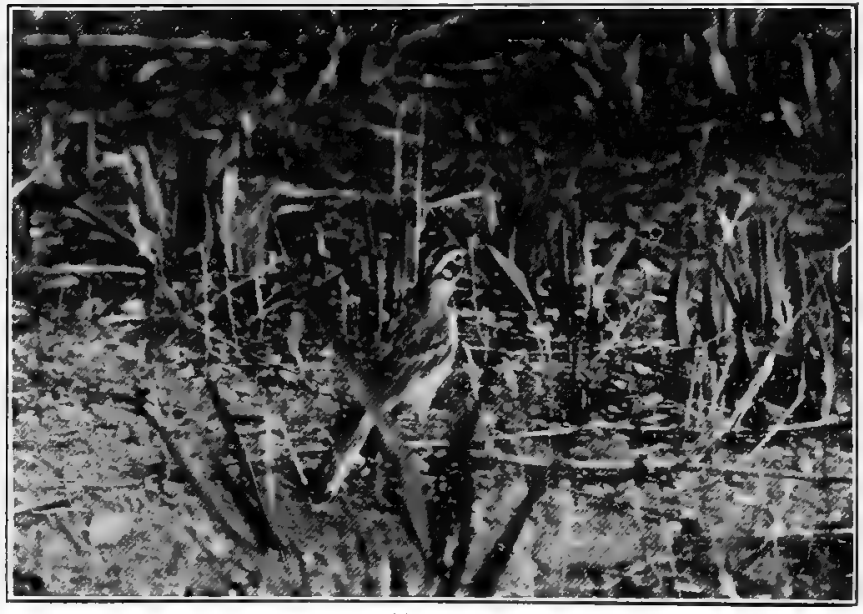

Western Lark Sparrow.

E. R. M.., Photo. Coiorado Springs. 
handsome plumage. Its range in winter is similar to that of the Magpie, from the plains to high into the mountains, up to Lake Moraine and Seven Lakes, 11,000 feet, but its breeding range is much more limited, being between 6,500 and 8,000 feet.

Its food consists of almost anything eatable, seeds, grain, insects, nuts, etc. A pair killed near St. Peter's Dome by Aiken, June 13, 1907, had been after food for their young. Fach had its mouth full of food, and had used discretion in gathering it. They had been first to the garbage pile of the station, and filled the throat with soft bread, after which they had caught several winged ants, grasshoppers and spiders that were held by the bill, extending along the length of the mandibles.

A nest was found by Warren in a gulch near Bear Creek Cañon, May 5, 1913, containing then 3 eggs, and there were + May 8, when the nest was collected, and which is now in the Colorado College Museum. The nest was 6 feet from the ground in a Douglas's fir sapling, only 2 inches in diameter at the base, and on a branch close to the stem of the tree. The outside diameter of the nest was about 10 inches, and it was 5 deep, the nest cavity being $4 \frac{1}{2}$ inches in diameter inside, by 3 deep. The outer portion was a loosely constructed affair of twigs, varying from $1 / 8$ to $1 / 4$ inch thick, while the inner portion was of fine rootlets closely put together, and with the walls of the cup varying from $1 / 2$ to $3 / 4$ inch in thickness. The structure was loosely laid on the few branches which supported it, looking as if it might easily fall off.

This species differs in habits from the Eastern Blue Jay, being less noisy, and not going in flocks in fall and winter, though parties of half a dozen or more are seen at times.

Aphelocoma woodhousei. Woodhouse's Jay.

Resident; rather common from the edge of the plains up to 7,000 feet. 
Woodhouse's Jay is a bird of the foothills, being found in the scrub oak brush along the base of the mountains, and the lower parts of the cañons, but not going to any great elevation; it is also found about Austin's Bluffs. Occasionally in winter it comes into town; from November 20, 1910, to April 16, 1911, at least four were about the north end of Monument Valley Park and vicinity and were frequently seen about houses four or five blocks east of the Park.

Aiken found two nests May 2, 1872, and his description was the first to be published of the nesting of the species. The nests contained 4 and 5 eggs respectively. His description is as follows: "Nest composed outwardly of dead twigs, then of fine roots, and lined with fine rootlets and horsehair. The eggs, four or five in number, are laid about May 1st. They are of a light bluish-green color, with the reddish-brown specks thickest at the large end."

When Aiken was at his ranch on Turkey Creek in October, 1873, a migratory flight of Woodhouse's Jays was seen. They were not flying high, but making short flights from point to point, always in a southerly direction. It was estimated that there were at least 500 scattered over from 50 to 100 acres of ground, as they kept lighting after their short flights. After this flight had passed the species seemed to be fully as common during the following winter as it had been during the summer. The flight had undoubtedly come from a more northern locality. Local birds appear to be non-migratory and are found in the same localities throughout the year.

Perisoreus canadensis capitalis. Rocky Mountain Jay. Camp Bird. Camp Robber.

A not uncommon resident of the higher elevations, from above 10,000 feet to timberline.

This species is a bird of the Hudsonian zone, where it spends most of its life, breeding in the heavy timloer very carly in the spring. Occasionally in fall and early winter it 
wanders lower down, and has even been seen in the streets of Colorado Springs. It comes about the houses of the care takers of the Colorado Springs water system in the mountains, at 10,000-11,000 feet, to pick up what scraps may be thrown out, and at times becomes very tame and familiar. It is quite easy to induce them to take food from one's fingers. They carry off more than they eat, presumably hiding and storing il for future use.

Corvus corax sinuatus. Raven.

Resident.

A few pairs of Ravens are resident on Pike's Peak about timberline, where it is said they are increasing in numbers and are supposed to breed in the "Crater." They are seen occasionally by occupants of the house on the summit and one was killed there by J. G. Hiestand in the autumn of 1912. It has been noticed near Seven Lakes in January and on Bison Creek, near Clyde, in September. In, winter they may descend to the plains at rare intervals, probably less often than 40 years ago. Several reports of a "crow" or "raven" seen have come to Aiken within the past few years, but the descriptions were not sufficiently accurate to make identification positive. One was caught in a trap and brought to Aiken in 1901, and Dr. W. W. Arnold kept one as a pet for two or three years which had been brought to him with a broken wing.

Corvus cryptoleucus. White-necked Raven.

Formerly a common resident, now unknown in the County.

The following quotation from Henshaw's Report on the Ornithology of the Wheeler Surveys published in 1875, gives an account of its former occurrence and habits:

$\mathrm{Mr}$. Aiken communicates the following:

"It seems to me not a little singular that I should have been the first to detect the presence of this bird in Colorado, 
for it outnumbers all the other Corvi in certain localities. It had previously been considered a bird of the southeast, and was supposed to be confined mainly to the Staked Plains of Texas, but I now know it to be common along the eastern base of the Rocky Mountains, throughout the entire extent of Colorado, and it even winters as far north as Cheyenne. It has also been found at Tucson, Ariz., by Capt. Bendire, who includes it among the resident birds of that locality, so that it has quite an extended range. I first saw them in October, 1871, about twenty-five miles south of Cheyenne, on the line of the Denver Pacific Railroad, where a large flock was hovering over the plain. In the city of Denver I have often found them searching for food in the less frequented streets, and about one hundred miles farther south, on the Fontaine Qui Bouille, I have seen immense numbers. At the latter place, a flock of probably one thousand individuals was resident during the winter of 1871-2. Although so abundant in winter, very few are to be seen in summer; the greater number either pass to the northward or become so distributed over the country as not to attract attention. Being seldom disturbed, these birds have little of the shyness which the common crow of the Last exhibits, though it is not always easy to get within gunshot of them. I have on one occasion ridden along within twenty feet of a fence on which sat thirteen of these 'imps of darkness,' only one of which flew away, the others contenting themselves by keeping a watchful eye on my demeanor, and an instant's halt on my part, or a suspicious motion, would have started them off instantly. C. cryptoleucus is mainly a bird of the plains, being replaced in the mountains by the common raven. The two birds resemble each other so closely in notes and habits that it is difficult to distinguish between them at a distance; the greatest apparent discrepancy being in size, though the croak of carnivorus (i. e. sinuatus) is somewhat deeper and louder than that of the other. I have sometimes found them both associated in the same flock. Each succeeding year since I first saw these birds I have noticed 
a marked decrease in their numbers in E1 Paso County, Colo. The cause of this I do not know unless it is because as the country becomes more thickly settled the solitude they love so well is denied them." Pp. 326-7.

Since the above was written Aiken has changed his opinion as to the cause of the disappearance of the White-necked Raven from this region. Some strong incentive was necessary to have induced these birds to wander northward from their native range in western Texas and New Mexico. This was offered by the slaughter and extermination of the buffalo herds on the western plains which was going on during the late sixties and early seventies. Pioneer settlers were pushing ahead of the railroads; transportation was by teams, and travelers camped along the roads and fed grain to their stock. The Ravens, probably first attracted by the buffalo carcasses that strewed the northern plains later followed along the routes of team travel and fed on scattered grain left by campers. By 1874 the buffalo were nearly gone; completed railroads had put the wagon freighters out of business; frequent houses along most roads provided shelter for travelers and camping became unnecessary; the food supply of the White-necked Raven was curtailed and the bird presently retired to its former habitat.

An unusual record for altitude is California Gulch, August 27, 1872 (Aiken).

May 17, 1878, Aiken found on Horse Creek, some sixty miles east of Colorado Springs, in what is now Lincoln County, a nest of the White-necked Raven which contained 7 nearly hatched eggs. Of two other nests of the same species found five days later, one contained 5 half-grown young, and the other 6 (traces of a 7 th having been broken) nearly fresh eggs. Nest cup-shaped, inside of hair and wool firmly matted and woven and outwardly built of dry twigs. 


\section{Corvus brachyrhynchos. Crow.}

Rare. The Crow has been taken so infrequently in El Paso County that it would seem to be nothing more than a straggler. There are but two specimens in the Aiken Collection, one without date, taken near Colorado Springs, the other from Monument, taken in November, 1906. It is strange it should be so rare here when there are many places north of the Divide where it is a common bird. This species was common 15 miles southeast of Colorado Springs in February and March, 1914, where they they were feeding on carcasses of sheep killed by heavy snowstorms.

Nucifraga columbiana. Clarke's Nutcracker. Clarke's Crow.

Not uncommon resident in the mountains, coming lower down in winter.

Like the Rocky Mountain Jay, by whose names of Camp Bird and Camp Robber it is sometimes called, Clarke's Nutcracker is a bird of the higher mountains, breeding quite early in the green pine and spruce timber. There is a full grown young of the year in the Aiken Collection, taken at St. Peter's Dome, June 21, 1907. It is rather more of a wanderer than the other species, and habitually comes down to lower elevations in winter and the early fall than that species does, Wetnore and Rockwell noting a number at Palmer Lake September 6, 1909. It is plentiful in the Turkey Creek valley in autumn. It has been seen at Lake Moraine in March, June and September, and at Seven Lakes in January. In winter it is found about the foothills and at Austin's Bluffs, and probably wanders and straggles over most of the region where there are trees. In September and October this species is apt to be found among the piñons, living on the seeds or nuts of that tree, getting them sometimes by clinging to a cone and hanging upside down from it and extracting the seeds from below, and again standing on top of a cone and reaching over and 
picking out the seeds from above. A pair noticed on the summit of Cheyenne Mountain in May, 1913, by Aiken, are thought to have bred there.

\section{Cyanocephalus cyanocephalus. Piñon Jay.}

Resident; common locally.

The Piñon Jays breed in the piñons and cedars, of which there are but a comparatively small area in the County, laying its eggs so early in the season that the young are out of the nest by the first of May. Late in the summer and early in the autumn they begin to wander about in flocks, often of many individuals, reaching both higher and lower elevations than their breeding range. Wetmore and Rockwell saw it at Palmer Lake September 6, and Warren saw one on Bison Creek, near Clyde, at 10,000 feet, September 8, 1911; extremely high for this species. In winter it is now common at Austin's Bluffs, near Colorado Springs, but thirty years ago it was very rare there or not seen at all. The reason for this change may be that in the early days there was no food for them about there, and now there is considerable farming with corn and grainfields where food may be found. Occasionally flocks may be seen flying over the city of Colorado Springs on their way tack and forth from their feeding grounds.

\section{Dolichonyx oryzivorus. Bobolink.}

Rare spring and summer visitor; no breeding records.

Allen and Brewster state that "A single specimen was brought to Mr. Aiken May 18, [1882], and another May 23; two others reported as seen. But two specimens were previously known to $\mathrm{Mr}$. Aiken as having been killed here."

There is a male in the Aiken Collection taken near Colorädo Springs, September 5, 1897. May 20, 1913, Warren saw two males in Monument Valley Park, and one on the 21st and 22nd. 
Molothrus ater. Cowbird.

Summer resident; common. Arrives about the last of April. Departs in October, has been seen as late as the 29th.

The Cowbird, well known for its habit of laying its eggs in the nests of 'other birds, is a rather common summer resident in much of the County. Bendire, in his "Life Histories of North American Birds," figures a Cowbird's egg taken from the nest of a Mountain Song Sparrow in El Paso County by Aiken, and Aiken took two eggs from a Meadowlark's nest near Ramah, June 4th.

Xanthocephalus xanthocephalus. Yellow-headed Blackbird.

Summer resident; common in suitable localities. Arrives the last of April, and departs in September.

Localities such as the Yellow-headed Blackbird prefers for breeding places are rather rare' in El Paso County, for swamps and sloughs with plenty of tules and rushes are their favored resorts, and there are not many such within our limits, Skinner's being the only place where we know of its breeding within the County. The nest is woven to the stems of the tules, and forms a rather deep cup in which 4 or 5 eggs are deposited.

\section{Agelaius phœniceus fortis. Thick-billed Redwing.}

Resident; common.

While the Red-winged Blackbird may be considered a resident species as some individuals remain through the winter, yet it is more abundant in the summer, the migrating birds coming in the spring about the first of March, or the last of February, the males always preceding their mates. Probably most, if not not all, the winter birds are a different lot from the summer residents. They are found all over the County, at least below the foothills, where there is such ground as they like, for they are always found near water, and breed throughout their range. 


\section{Plate XVII.}

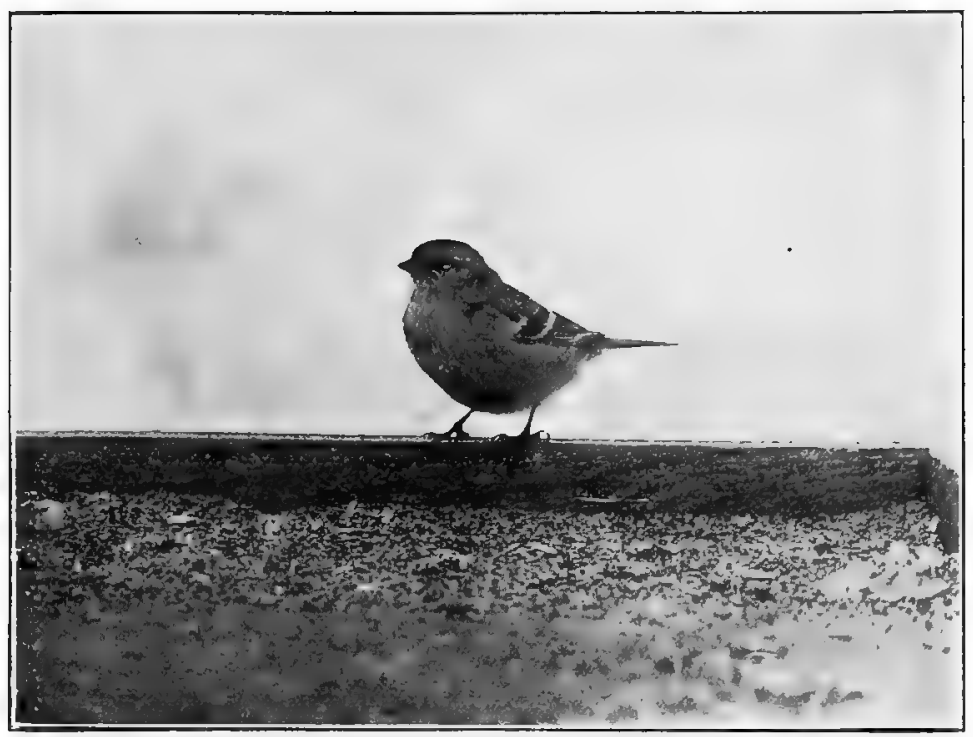

Fig. 3 .

E. R. W., Photo.

Western Tree Sparrow.

Colorado Springs.

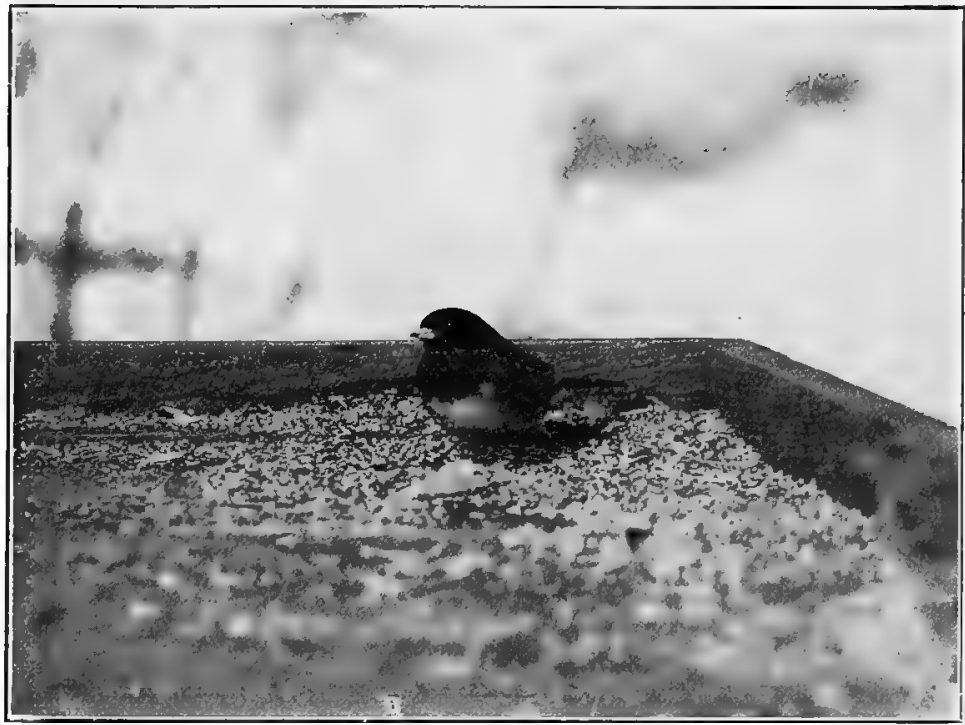

Fig. 32 .

INTER MEDIATE JUNCO.

E. R. IV., Photo.

- (In a photograph Shufeldt's Junco would look very like this). Colorado Springs. 


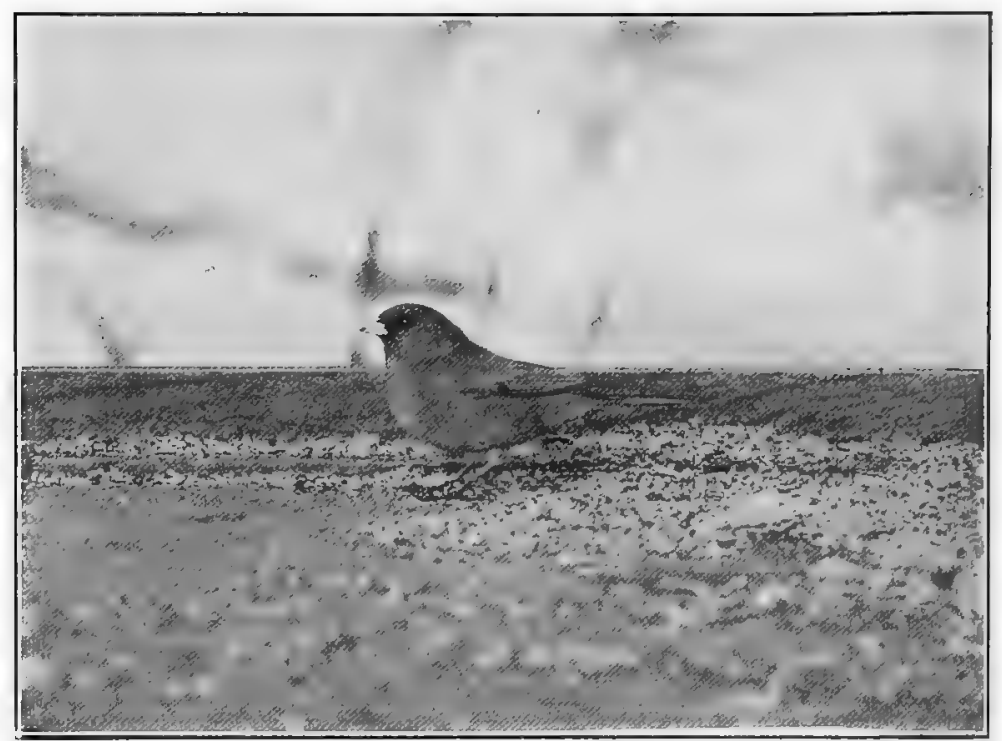

Fig. 33.

E. R. W.. Photo.

Pink-Sined Junco.

Colorado Springs.

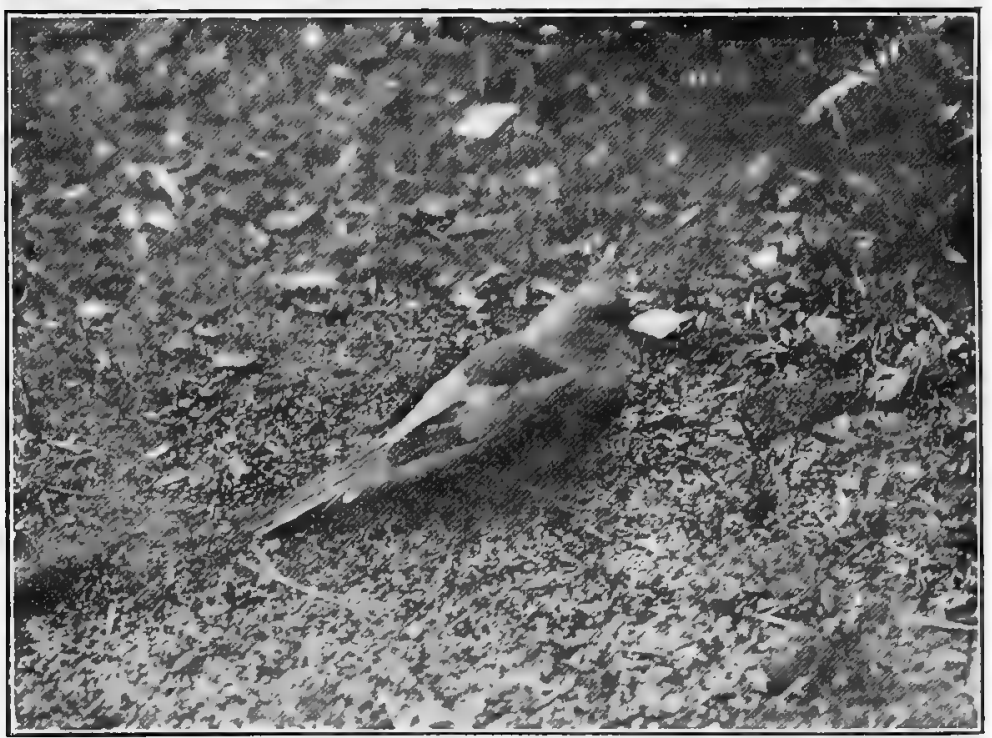

Fig. 34 .

E. R. IY., Photo.

Gray-Headed Junco.

Gunnison County, Colo. 
All the Redwings in the Aiken and Warren Collections have recently been examined and identified by $\mathrm{Mr}$. H. C. Oberholser of the Biological Survey. These included 22 specimens from the region now under consideration, taken at various dates through the year from January 24 to November 20 , and all were labeled by $\mathrm{Mr}$. Oberholser as $A$. $p$. fortis.

\section{Sturnella neglecta. Western Meadowlark.}

Summer resident; common; a few often spending the winter. Arrives early in March, sometimes the last of February. Departs late in October or early in November.

One feels as if spring had really come when he hears the Meadowlarks singing from the light and telephone poles in town, and the fence posts along the roadside, for they are no sooner here than they announce themselves with their cheery notes. Found everywhere on the plains region, and in the lower portions of the mountains where there are open spaces, it is one of our commonest species, and most useful as well, living very largely on insects of all sorts, of which it destroys vast numbers in a season.

Two broods are raised, sometimes at least. In the summer of 1903 a pair nested and raised two sets of young in a vacant lot at the corner of Cascade Avenue and Caramillo St., in Colorado Springs, with houses all about them. September 8 , 1904, a young bird hardly able to fly was seen on the outskirts of the town. The nest is built on the ground, usually well hidden in long grass, often with more or less of a dome-shaped roof of grass above it. The eggs vary from four to six. June 4,1909 , a nest with one egg and one young bird several days old was by the Cañon City road several miles southwesterly from Colorado Springs.

The song of the Western Meadowlark has been the theme of many writers, its beauty and variety arousing the admiration of all who hear it: Mrs. Sturgis has lately published a little book with words and notes of a number of songs as heard 
about Colorado Springs; Keyser could hardly find words to express his admiration and wonder of the lark's music, and others have written in the same strain.

June 4-7, 1898, Aiken made notes on Meadowlark songs at Ramah, as follows:

"The variety of its song is quite remarkable. I noticed some styles of song different from those in the vicinity of Colorado Springs, and some that are the same. It is a common thing to hear a certain lark that has been singing one song for a time change to another in different key, and with different notes and inflections. I take it that each bird has two songs. Two by one individual which I noted were: see, ching-ling, chick-le-pup, and see-saw, chick-a-lit-tle, chick-a-loop. The song consists usually of seven or nine notes or syllables, a combination of clear flute or whistling notes with liquid and guttural tones. Usually one or two notes receive special emphasis, and the variation of accent is one point of difference. It is often on the last note but is also given on various notes in the song. The different key in which different songs begin and end is another point, but the notes themselves differ widely in different individuals. The following songs are most often heard at Colorado Springs, and also at Ramah: See-saw-see, bil-leeco-bah; co-que-co, queed-lick, tweè-pah; bah beèp-a-lo, chucka-luck. In the last the first part is the conspicuous part, but in the two others the last part is most pronounced. I also note at Ramah the following: ta ti ta ta, ta-ty-ta, the second note on a higher key, and the last three uttered like tremolo; eè too, eat a little ee-tle doo-ple." Subsequently to writing this Aiken heard five of the familiar songs uttered by one bird within a few minutes.

In June, 1900, he made the following note on the song of a lark at Hartsel, Park County: "I heard a song I had never heard before, 'Come Wil-lie, come quickly home.' I had almost"concluded the mountain larks had songs unlike 
those of the plains, when the same bird sung one of the most familiar ones."

Icterus bullocki. Bullock's Oriole.

Summer resident; common. Arrives about May 10. Most of them leave the latter part of August; the latest date at hand is September 14, 1903.

Orioles are found all over the County wherever there are trees, below 8,000 feet. When the leaves are gone from the trees in autumn many of their pensile nests are seen hanging from the extremities of the branches, testifying to the abundance of the builders. Practically all the nests are built in the cottonwood trees, these being the most suitable kind we have for their style of architecture. They are at home in the towns as well as in the country, and Monument Valley Park is a favored place for them. A male of this species in the Aiken Collection taken at Ramah, June 5, 1898, is peculiar in having no black on the head, this being rather bright yellow.

Euphagus carolinus. Rusty Blackbird.

Rare; but one record for the County, 3 seen and 2 killed by Aiken at Skinner's, January 15, 1908. There are only a few records of this species for Colorado, and this is the only one south of the Divide.

Euphagus cyanocephalus. Brewer's Blackbird.

Summer resident; common. Arrives the last week in April. Most of them are gone by October first, but it has been known to remain until January 1.

Brewer's Blackbird is one of our most common summer birds, seen everywhere about the ranches on the plains and up into the mountains, where a great many breed, gathering after the breeding season is over into flocks, often of large size. Since Monument Valley Park has been established a number are there every season, at the north end, and L. L. Shaw found 
a nest there, May 28, 1912, which contained 3 eggs. At Ramah, June 4, 1898, nests contained young and eggs in advanced stages of incubation. It nests in all sorts of situations, in trees and bushes, on the ground, and even in haystacks.

\section{Quiscalus quiscula æneus. Bronzed Grackle.}

Summer resident; only locally common. Arrives the last of April, the earliest date being April 19, 1899. Departs early in autumn.

The Bronzed Grackle breeds in colonies, and there is one near Buttes on Fountain Creek. The birds probably leave as soon as the young can fly well, and no doubt all leave the County long before winter sets in.

\section{Hesperiphona vespertina montana. Western Evening Gros-} beak.

Resident; locally and irregularly common.

The Evening Grosbeak is better known as winter visitor than as a summer bird, for but few of us are favored with a sight of it at the latter season, though Aiken has seen the species in the County every month in the year. And as a winter visitor it is decidedly irregular, for several winters may pass without one being seen, then there will be numbers around town, always going in flocks and feeding in the yards and among the trees. They are usually tame and approachable then, and easily observed. They probably breed in the mountains in this region, but their nesting places have not yet been lucated.

June 19, 1898, Aiken found in the oak thickets of the lower foothills near Bear Creek a flock of 25 or 30 Evening Grosbeaks, from which he killed five males. Both sexes were together and had probably come down off the mountains to feed on the larvæ of insects that were devouring the leaves of the oaks. The contents of the gizzard of one bird examined 
appeared to consist of small black seeds mingled with the insect larvæ. The testicles in all were of the size of large beans and indicated that the birds were either breeding or on the point of doing so.

Pinicola enuclcator montana. Rocky Mountain Pine Grosbeak.

Resident in the mountains. More common in winter.

It is difficult for us to say with the information at hand what is the abundance of the Pine Grosbeak in this region, but we do not consider that it is at all common even in the localities where it dwells. It is a mountain bird, and seldom, with us, descends to the lower altitudes, but remains above 9,000 feet most, if not all of the year, and does not seem to be given to those wanderings which bring its eastern consins ciown from the north into the eastern states, often penetrating a considerable distance south. It was seen and taken by Warren above Seven Lakes, 11,000 feet, in January, and also seen by him on top of Cheyenne Mountain, November 21, 1905. In the case of those seen at Seven Lakes the care-taker at the Strickler Tunnel said they had been about there all winter. They were in the willows when seen. Aiken has had several specimens from near timberline on Pike's Peak.

\section{Carpodacus cassini. Cassin's Purple Finch.}

Resident.

Cassin's Finch is a resident of the mountains, where it breeds, coming down to the foothills and edge of the plains in fall and winter, but rather irregularly, not being observed at a!l some seasons. At this season it is found in flocks, which at first sight seem to be composed largely of females, but many cif the supposed females are really males in their first winter plumage, which is practically identical with that of the female. They frequent the trees and bushes along the streams, in the 
foothills, and at the bluffs. It is doubtless more or less common in the pines on the Divide, and has been noted at Eastonville early in March. We have no records of its occurrence in the mountains in this region in summer, though it should breed among them as it does elsewhere in the State. Our winter residents are doubtless migrants from more northern localities.

Carpodacus mexicanus frontalis. House Finch.

Resident; common about towns.

House Finches are town rather than country birds with us, apparently preferring the neighborhood of human habitations, and are about the only birds we have which seem able to hold their own against the imported House or English Sparrow. While resident the year through, it seems possible there may be a slight migration, a portion going south in winter, for they do not seem as abundant at that season as in summer, though that is partly accounted for by the fact that the birds do leave the neighborhood of houses and go out among the fields searching for food. However that may be, they return in good season, and in early March the brightly clad males may be heard singing sweetly and courting their mates. They build their nests about houses and other buildings, as well as in trees.

In 1903 a pair built their nest on the cap of a column on the porch at my home, beginning to build April 20. There was one egg in the nest the evening of April 27; 3 eggs on the afternoon of May 1; 4 eggs May 4, but I have no notes of the intervening days. The three days preceding May first the female spent a good deal of time on the nest as the weather was cold. The morning of May 12 there were 3 young in the nest and one egg; about six o'clock in the afternoon I saw the female eat most of an eggshell; possibly the last egg had just hatched. From May 12 to $28 \mathrm{I}$ photographed these young birds daily, sometimes one, sometimes all four. May 26 the largest escaped from me and flew across the street, alighting in a tree, where its mother afterwards fed it; all the remaining young left the nest May 29.

(E. R. W.) 
Two broods are, sometimes at least, raised in a season, and possibly three. September 3, 1903, young House Finches were noticed which seemed to have just left the nest. Lloyd Shaw found a nest May 26, 1912, containing 4 eggs, and on the 28th there were 3 young; presumably these eggs were laid from the 12th to the 16th of May. June 16, 1912, a young bird just from the nest was seen in Monument Valley Park. 'Two broods were hatched in one nest in 1913; the first hatched June 2 or 3 , the second flew July 25 .

The food of the House Finch consists largely of seeds of various sorts. They sometimes eat the seeds of that pest the dandelion, in fact Dr. W. H. Bergtold says the young are largely fed on those seeds. In the fall they have been seen eating the seeds of Clematis paniculata which was growing over a porch.

"A comparison of House Finches collected in E.1 Paso County with specimens from California, Arizona and New Mexico, shows the local bird to be consistently darker with broader streaks beneath, olivaceous brown rather than hair brown. White of underparts purer or ashy, lacking the buffy tinge; the red more crimson. Bill and feet more robust and darker. Culmen shorter $(10 \mathrm{~mm}$.), little more than depth of bill at base. Average length of 11 males $153 \mathrm{~mm}$; average of 17 males, Wing, $78.3 \mathrm{~mm}$. ; Tail, $61.3 \mathrm{~mm}$.

I conclude that the House Finches of Colorado east of the nountains and probably of southeastern Wyoming are subspecifically distinct from those of California, Arizona and New Mexico at least as far east as the Rio Grande River. If further investigation proves this conclusion correct the more western and southern form becomes Carpodacus mexicanus ubscurus McCall. Local birds are true frontalis since Say's type locality is the Arkansas Valley.

Our House Finches are in part migratory and in part nonmigratory. There are the same smoke-soiled birds with us 
through the winter which breed here in the summer and there is no evidence that any wintering birds are from more northern localities. In April I meet clean plumaged birds coming north from their winter resort. Flocks of House Finches are seen migrating in autumn; August 13, 1907, I noticed flock after flock passing south along the Fountain at Skinner's six miles south of Colorado Springs. Young birds gather in weedy fields in August where they linger a few days until the autumn moult is completed and then most of them go southward, probably led by old birds. The percentage of these which return in the spring seems to be small.

I first met with House Finches near Cañon City, April 26,1872 ; a flock of several hundred were sweeping through the valley. In the May following I found 2 or 3 pairs nesting in the piñon hills northeast of there. I found none nesting in those early days in Cañon City, Pueblo, Colorado Springs, or Denver, but at Trinidad, in July, 1872, I first saw them utilizing human habitations. It was many years before the northern birds took up with the advance of civilization and made their homes in towns. When I returned to Colorado, in December, 1895, after some years absence, I found them frequenting the city. The spring following a pair built their nest in a wistaria vine close under the eaves of my front porch and directly over the steps. They raised a brood and went off with the young as soon as they could fly, and were not seen again until the following spring (1897), when they cleaned and reoccupied the old nest.

When the young in this nest were half grown the parents built a second nest under my neighbor's porch and while the male was attending the first brood the female raised another. In 1898 the breeding impulse was even stronger. The male was first noticed December 27 of the previous year to come and inspect the old nest. At intervals of ten days he came after that for several weeks before he brought his mate. In March the pair cleaned and relined the old nest and the female 
began incubating. Soon after the young were hatched a second nest was built adjoining the first and attached to it in which a sfcond complement of eggs was laid and the female sat on these while the young were growing in the first nest beside her. When the second brood were hatched a third clutch of eggs was laid in the nest now vacated by the first brood and a third brood successfully reared. A chronology of the domestic affairs of the pair for the next year, 1899, follows:

March 8. Male bird seen inspecting the old nest.

April 13. Both birds had been house-cleaning since March 17 and had relined the original nest.

April 25. Female sitting and the male keeps out of sight.

May 8. Five young hatched.

May 28. Nest deserted and both parent birds presumed to be with the young instructing them to provide for themselves, but returned a few days later.

June 11. Female incubating second laying.

June 23. Second brood of young several days old. Male not seen but heard singing in early morning.

July 3. Young of second brood left the nest.

In 1900 the male was seen inspecting the nest January 13 , and the female joined him February 23. March 8 the old nest was relined. The first laying of eggs was thrown out of the vest April 16 but April 20 the female was incubating a fresh set, and May 11 the young were about a week old.

In 1901 one brood was reared.

In 1902 the pair seemed much annoyed to discover that English Sparrows had occupied their nest as a roosting place but finally renovated it and occupied it about May 20. One brood raised.

In 1903 the pair came early and finding their nest demolished by sparrows built elsewhere in the neighborhood. 
In 1904 the pair appeared March 3 and after lingering about the old nest sometime began carrying material from it across the street where the nest was constructed. Work done by the female closely attended by the male. English Sparrows then built their own nest on the platform of the denuded finch nest.

In 1905 the pair of House Finches came February 26 and for nearly a month kept near the old nest which they seemed bent on reoccupying, but on March 11 a catastrophe occurred which closed their life history. In attempting to destroy the pestiferous English Sparrows I accidentally killed both finches. much to my regret. They had for ten years been members of my domestic family. Their skins are preserved in the Aiken Collection in Colorado College, their original numbers being, male, 4577 , and female, 4578 .

My excuse for relating this extended history is that I believe that some light may be thrown upon the breeding habits of various other species of birds by the application of my narration. I have space to point out but one point here. I assume and am convinced that the birds were in their first reproductive year when they built the first nest. They reached the height of reproductivity in the third year when they raised three broods. In succeeding years they dropped to two broods and then to one. This may be accepted as a law or rule applicable to other species whose habit is recorded of producing two or more broods in a season. We may conclude that the more vigorous pairs produce two or more broods some seasons but other pairs may produce but one.

Breeding male House Finches show a variable amount of red in the plumage. Those with the least I have supposed to be birds of the previous year which would acquire the full plumage at succeeding moults, concluding also that deficiency of red characterized all birds of the year. I think this is the prevailing view. In 1907 I made investigations which throw some light on the subject. Young birds take on the coat woru 
through winter and the following summer about three months after leaving the nest. A large proportion of them and of adults as well moult in August. The new feathers grow out through the feathers of the old coat, gradually displacing them.

I observed at this time that moulting young males were acquiring as extensive a distribution of red as the brightest colored adults, in fact after completion of the moult in both young and' adult they are not distinguishable. Several specimens illustrating this moult were preserved. Evidently then the maiority of young acquire the perfect coat at the first autumnal moult.*

Later in 1907, on October 4, I obtained an undoubted young male just completing its moult which is indistinguishable externally from a female at the same season except perhaps for a faint tinge of red on the jugulum. It suggests a parallel case to that of Carpodacus cassini in which young males regularly take the coat of the female at the autumnal moult. What may take place in further development of the plumage in such cases as that of this imperfectly marked House Finch is open to further investigation. Possible conclusions are that it might develop some increase of red at the breeding season and acquire a perfect coat at the second autumnal moult, or it might develop at the second moulting a phase of scanty red diffusion that would exist through life and prove an individual variation, perhaps an individual characteristic transmittable to progeny.

Orange-red mingled with or displacing crimson-red in House Finches is accepted as indicating age. A male taken May 22, 1904, shows a scanty reddish area of the orange shade, so probably this bird lived a number of years without increasing the amount of red.

*The red of the autumnal coat remains pinkish through early winter, gradually deepens toward spring, and acquires its greatest intensity at time of breeding without a spring moult or apparent abrasion. 
Finally, it seems probable that these birds acquire no material increase of the red, area after the second summer, and that the extent of red is not dependent on age."

$$
\text { (C. E. A.) }
$$

\section{Loxia curvirostra minor. Crossbill.}

Resident in the mountains; locally common.

Aiken found several about St. Peter's Dome in June and July, 1907; also at Palmer Lake, June 26, 1907. Allen and Brewster reported seeing a flock of about thirty at Austin's Bluffs, April 26, 1882, and also noticed a few both there and elsewhere at both earlier and later dates. Two birds taken at St. Peter's Dome on June 13 were apparently just completing their moult, and one taken at Palmer Lake, June 26 was in the midst of moulting.

\section{Loxia curvirostra stricklandi. Mexican Crossbill.}

There is in the Aiken Collection a male Crossbill collected on Turkey Creek, May 22, 1874, which is much larger than the other birds just mentioned, and has a much larger bill. Sclater referred this to stricklandi, while Oberholser calls it bendirei Ridgway, but this latter subspecies has not as yet been recognized by the $A$. O. U. There is a female in the same collection belonging to the same form, and having a label with the same date, but which was really taken in the White Mountains, Arizona, in 1876 , by Aiken.

\section{Leucosticte tephrocotis tephrocotis. Gray-crowned Rosy} Finch.

Winter resident; irregularly common.

This species, in common with the two succeeding species of Rosy Finch, is a winter visitor with us, but quite uncertain in its occurrence. Probably they are fairly regular in their appearance in the mountains, but lower down, below the foothills, they do not come so often, though Aiken has collected a 
nitumber in various winters near Colorado Springs and Colorado City. Occasionally it comes right into town; thus one was seen December 29, 1902, near the Plaza Hotel in Colorado Springs, and February 12, 1903, two were seen feeding with a large flock of Horned Larks on millet seed which had been put out for the latter. They are often about the caretaker's house at Lake Moraine in winter. Rosy Finches are sociable birds and are almost always found in flocks, frequently of many individuals, and sometimes including all four of the forms which are found in Colorado. In April, 1874, a flock fed about Aiken's dooryard in Colorado Springs and he captured some alive and kept them in a wire cage for a time. They evinced no fear and would occasionally sing an unpretentions trill.

Leucosticte tephrocotis littoralis. Hepburn's Rosy Finch.

Winter visitor; not common.

This species is found associated with the others, but is not nearly as common. Aiken has taken a few near Colorado Springs and Colorado City, and Warren took two at Lake Moraine, December 12-13, 1906, and saw one a mile southwest of Colorado City, November 7, 1913, in company with about a dozen of the preceding species.

Leucosticte atrata. Black Rosy Finch.

Winter visitor; not common.

The type of this species was shot by Aiken at Cañon City and the name atrata was suggested by him to Ridgway. The Black Rosy Finch has been met with a number of times in El Paso County where it occurs as a winter visitor with considerable regularity and at all altitudes. Like others of its kin it is a mountain bird but is sometimes driven down to the plains by snow. Aiken obtained specimens from the summit of Pike's Peak in 1877, Colorado City in 1878, and from near Colorado Springs in 1883, while Warren found it at Lake 
Moraine in December, 1905, and March and December, 1906, and secured a good series of specimens.

Leucosticte australis. Brown-capped Rosy Finch.

Resident; common.

The Brown-capped Rosy Finch is a resident species, living in summer on the summits of the mountains above timberline, and was first met with by Aiken on the summit of Pike's Peak, July 4, 1873. The nest has never been found, but if its nesting habits are like those of the Gray-crowned species, or rather the Sierra Nevada Rosy Finch, the nest will be found hidden under stones in rock slides, for such was the situation of the nest of its relative recently discovered in California. In summer it may be seen flitting around the mountain slopes, searching for food, often, even in what would seem to be the breeding season, two or. three together. In autumn, when the weather becomes more severe, and food possibly more difficult to secure, they go lower down and join with their visiting relatives, the three preceding species, and make up large flocks, and in these it often seems to be in a minority as compared with the Gray-crowned. No doubt some of this species migrate farther south in winter, leaving their places to be filled by the others.

\section{Acanthis linaria linaria. Redpoll.}

The Redpoll is a decidedly rare winter visitor with us, and not often seen; possibly it may be more common in the mountains; Warren found it at Lake Moraine in December, 1906. There are specimens in the Aiken Collection taken in the winter of 1878-9, near Colorado Springs, and also one collected in Fremont County, April 25, 1872, which seems an unusually late date. Dr. W. W. Arnold reported a flock of 25 about Colorado Springs the winter of 1910-11, and noted that the birds ate the cottony scale on the maple trees. 
Astragalinus tristis tristis. Goldfinch. "Wild Canary."

Summer resident; common.

It is somewhat difficult to separate the records and occurrence of this from the following subspecies, as a sufficient series of specimens for the purpose is lacking. With the exception of the few which sometimes spend the winter the Goldfinches arrive early in May for the summer and are quite common over the County below 7,000 feet.

\section{Astragalinus tristis pallidus. Pale Goldfinch.}

Summer resident; common. Found occasionally in winter.

Aiken considers that the Goldfinches which spend the winter in the County are all pallidus, and that the summer residents along the foothills are mainly this species, while most of the typical form are found toward the eastern portion of the County. More collecting of specimens is, however, necessary to fully settle these points. Summer birds soon lose the paler edges of the feathers by abrasion and are then not noticeably different from the preceding form.

Astragalinus psaltria psaltria. Arkansas Goldfinch.

Astragalinus psaltria arizonæ. Arizona Goldfinch.

Astragalinus psaltria mexicanus. Mexican Goldfinch.

Summer resident; common. Typical psaltria usually arrives the third week in June; extremely early dates are April 21, 1900, and May 13, 1898, and specimens taken at these dates were still in their winter dress. Most of them leave in September and October; an unusually late date is that of a specinen from Beaver Creek, Fremont County, November 11, 1872. This is still in summer dress.

The A. O. U. Committee has eliminated the last two of 
the above named forms from its Check-List, regarding the differences in color as being due to age, this being the position taken by Oberholser in a paper published in 1903, in which lie states that a series of summer males from Colorado Springs "exhibits all gradations from the green-backed to the blackbacked forms, representing thus psaltria, arizonce, and mexicanus--all breeding at the same place!" It is very true that the series of males in the Aiken Collection represents these gradations, but there is one point that has been overlooked with regard to the occurrence of these birds in El Paso County, at least, and that is psaltria alone is the breeding form, so far as at present known, the dark forms not making their appearance until later, arizonce coming in July, and mexicanus the very last of July and first of August, and their actions then would indicate that they have but just arrived, nor have any dark colored birds been discovered breeding in the County.

The dates of skins of psaltria are April 20, 1900; June 25, 1898; July 23, 1899; August 15, 1907 ; September 2 and 5, 1897. Of arizone, July 16, 1872 (Fremont Co.) ; August 5, 1898 (2); August 6 and 7, 1897 ; August 12, 1907. A bird seen by Warren, June 15,1912 , appeared to be this form. Mexicanus, August 4, 1898; Salida, Chaffee Co., August 3, $1908 ; 5$ or 6 seen by Aiken in yard August 11, 1907. Dr. Bergtold reported seeing one in Denver, June 30, 1908, but did not collect it.

The evidence of the specimens and of field observations agree very well, though it is only fair to state that it is difficult to always distinguish arizone from mexicanus in the jield, as the birds almost invariably appear darker than they really are. These Goldfinches are often seen about the town on vacant lots, especially where sunflowers have grown up and gone to seed, and are easy to approach and observe, so that one can readily study them. An examination of the plumage of these specimens gives us no clue, for it seems perfectly fresh and unworn. A possible explanation which occurred was that 


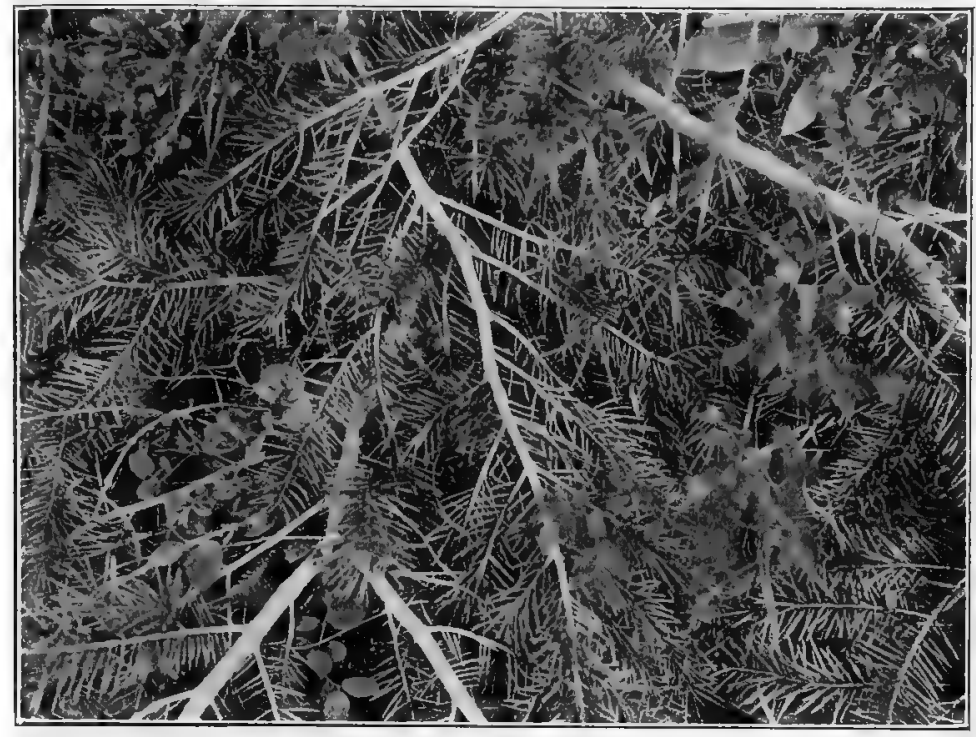

Fig. 35 .

E. R. W., Photo

ilie Nest Unoer the Protecting Branch.

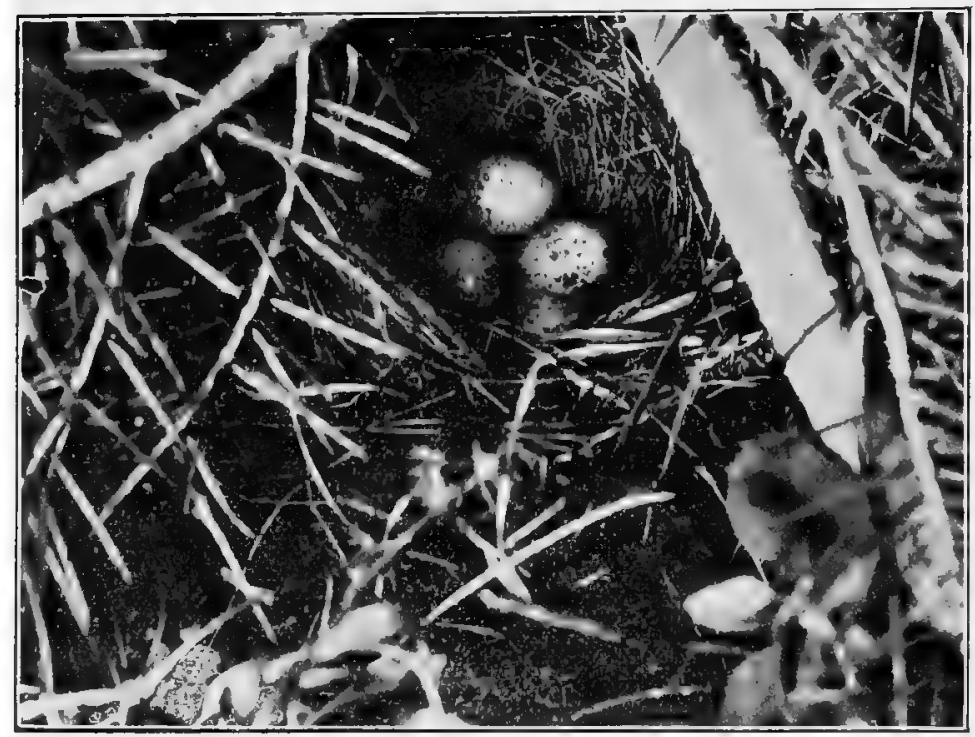

Fig. 36.

E. R. II... Photo.

Nest and Eggs of Gray-Headed Juxco; a Close liew. Near Golden, Colo. 


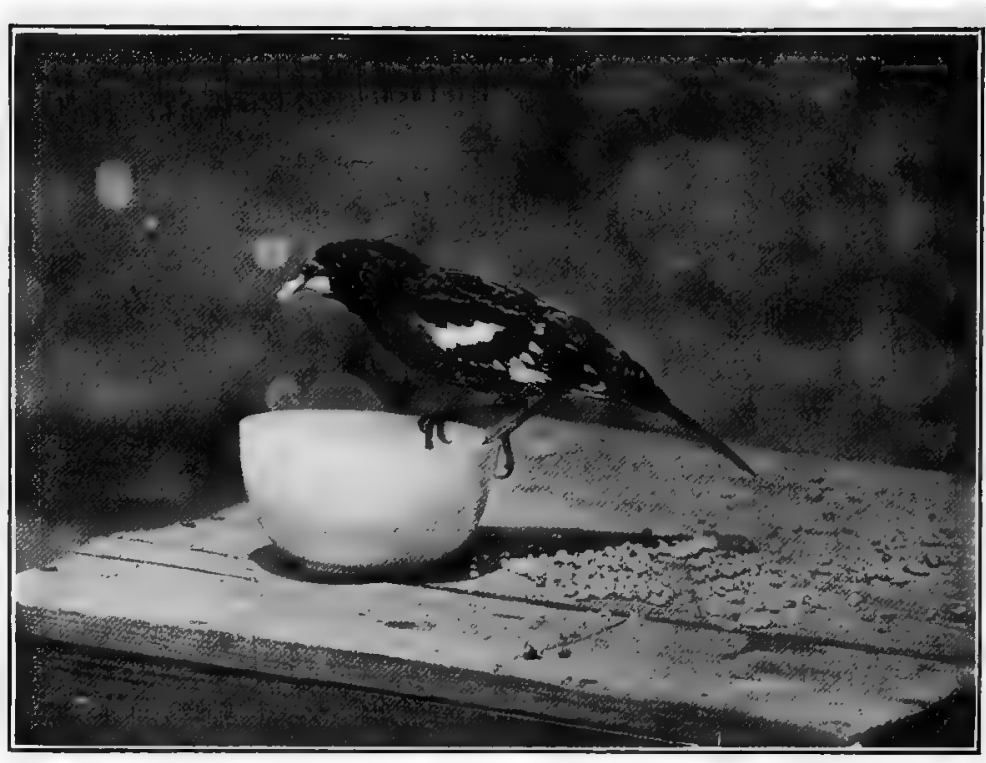

Fig. 37.

E. R. W., Photo.

Male Black-Headed Grosbeak. Ivywild.

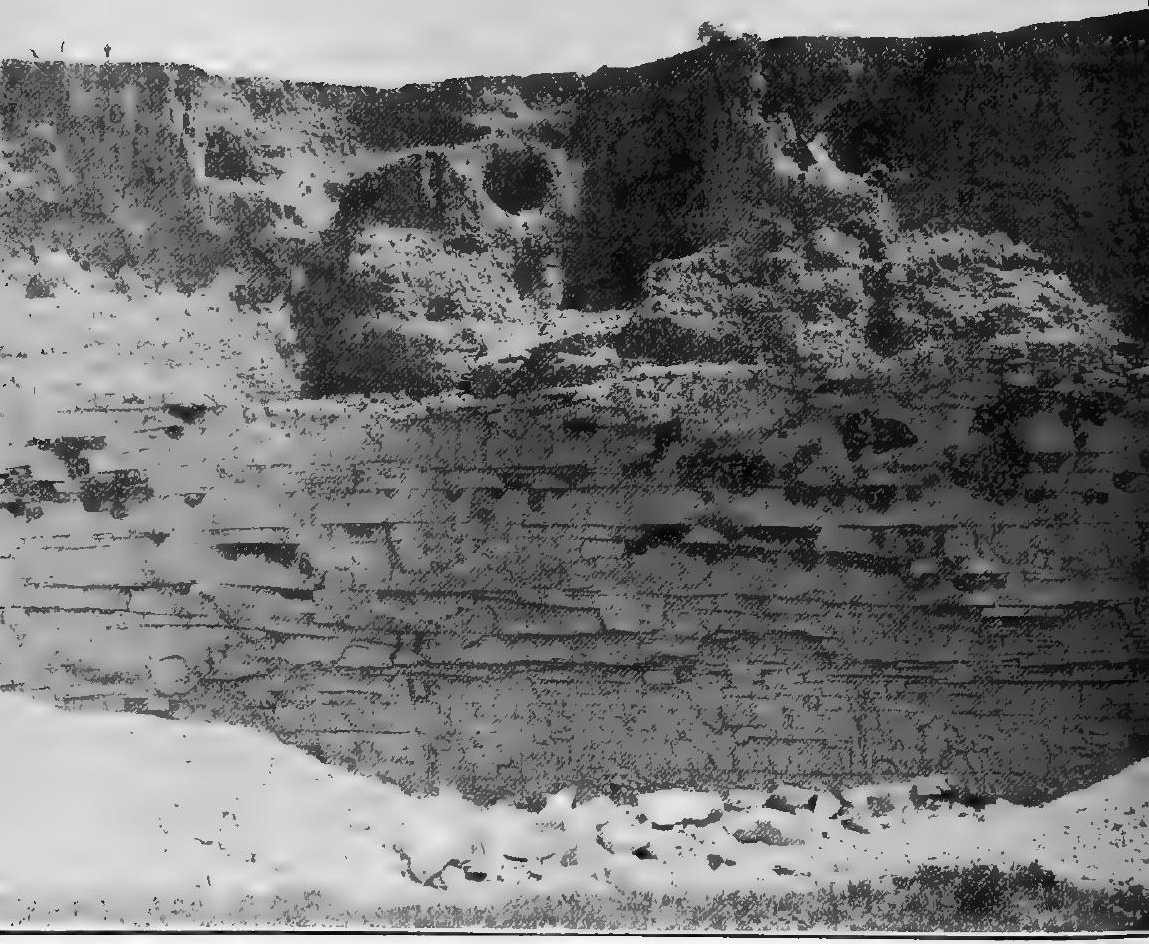

Fig. 38 .

Colony of Cliff Swailows.

E. R. H., Photo.

- Weld County, Colo. 
the differences in color might be due to the wearing away of the outer portions of the feathers leaving a dark inner portion exposed, but the plumage of psaltria shows no dark portions of the back feathers which could be thus exposed by wear, though we have examined specimens taken August 15 which are much worn, and as stated above the dark skins show no indication of any such wear.

To summarize: Psaltria is the flrst of the three forms to appear here in spring, and seems to be the breeding form; arizonc makes its appearance in July; while mexicanus, the darkest of the three, does not appear until about August first. After that time all three forms are to be found and in flocks together.

We have tried to present the facts in this puzzling case as clearly as possible, feeling the settlement of the matter by the A. O. U. Committee is not as satisfactory as it might be.

Two of the males in the flock noted as seen in yard August 11 were quarreling over a female.

Besides sunflower seeds the species eats almost any sort of weed seeds, including those of the dandelion.

Spinus pinus. Pine Siskin. Pine Linnet. Pine Finch.

Resident; common.

Pine Siskins are probably found at some season of the year over all the County where there is any cover for them, but they are rather irregular in their occurrence, at least in winter, and some seasons but few will be noted. The winter of 1910-11 a large flock was about the north end of Monument Valley Park, while the following winter but few were seen. It ranges at least as high as Lake Moraine, where Aiken has taken it. May 16, 1913, a pair had a nest at Ivywild, in a cottonwood tree, well out on a branch 30 feet above the ground. The birds could be plainly seen at the 
nest and identified. Dr. Arnold has seen this species eating the cottony scale on maples trees.

Passer domesticus. House Sparrow. English Sparrow.

Resident; common about towns.

The House Sparrow was first seen by Aiken in Colorado Springs in 1895, on his return after an absence of a few years. At that time there were several flocks about the town, most of which had probably been hatched that season, and numbering about 50 birds; the following year it was estimated there were 500 birds in the same area. The species probably reached the town in the spring of 1895.

While the English Sparrow, everything considered, is a pest and a nuisance, it does do a little good, possibly due to the fact that it is greedy and omnivorous, and will eat almost everything which comes its way. It has been seen to catch grasshoppers and feed the fledged young with them in the street; to work about in the grass of a lawn, and dig up worms or grubs of some sort, probably cutworms; also to eat some sort of plant lice on the branches of trees.

A good many summer in Monument Valley Park, and then lcave in the fall, presumably going up among the houses for the winter, though it is probably there is a partial migration in autumn as there are not as many of the birds around the town in winter as in summer, and they become numerous again in the spring.

September 24, 1912, a partially albino male House Sparrow was seen near a residence in Colorado Springs. There were one or two white feathers in the right wing, either the last primaries or first secondaries, and one or two of the inside feathers on the right side of the tail were white. When the bird flew these white feathers in the spread wing and partly spread tail made a striking contrast with the rest of the plumage. lt was never seen again though often looked for. 
In spring, before they begin to breed, on a bright day, especially after a storm, a flock will often gather on a bush or the roof of a building, and sing and twitter together, having as much of a song as some of our other sparrows.

Aiken has traced the progress across the plains of this undesirable alien by ascertaining from residents through western Kansas dates of its appearance at different points along the line of the Rock Island Railroad. He estimated that the westward advance of the invading army of sparrows was at the rate of about 50 miles a year.

Plectrophenax nivalis. Snow Bunting.

Winter visitor; rare, but one record of its occurrence in El Paso County, a pair taken by Aiken at Colorado Springs, in 1874. These are mounted and in the Colorado College Museum.

Calcarius lapponicus alascensis. Alaska Longspur.

Winter visitor; very irregular.

In the Aiken Collection are specimens taken near Colorado Springs, January 5, 1874, at which date a large flock was reported to be near town, and 20 specimens were brought in; specimens were also taken December 28 and 29, 1876; January 12, 1877. In Jantuary, 1884, Warren took one on each of three different days, always with a large flock of Horned Larks.

Calcarius ornatus. Chestnut-collared Longspur.

Winter visitor; common in certain localities. Arrives in September, Aiken having seen it September 12, 1897, on the plains east of Colorado Springs ; later in the same year, October 3 and 13, he found it at Broadmoor Ranch, his notes mentioning the Longspurs being in alfalfa fields which had been mowed close. The species was near Colorado Springs in February, 1899. In the seventies, when living on a ranch 
on Turkey Creek, Aiken used to frequently see this and the following species on the open ground between there and Fountain, out of the foothills. Allen and Brewster saw about 20 May 9, 1882, securing five. This is the latest spring date we have.

\section{Rhyncophanes mecowni. McCown's Longspur.}

Winter visitor; irregular. Not quite as common as the Chestnut-collared.

. January 14, 1884, Warren took one just north of Colorado Springs. This and the Alaska Longspurs were taken at a time when we had severe cold weather with a little snow on the ground. On the north edge of the city, somewhere about the end of Wahsatch Avenue, were large flocks of Horned Larks, and it was with these the Longspurs were found. Allen and Brewster took one May 9, 1882, with the before mentioned flock of Chestnut-collared Longspurs.

\section{Poccetes gramineus confinis. Western Vesper Sparrow.}

Summer resident; common. Arrives usually about April 18, the earliest date being April 9, 1899. Are probably gone by about October first, the latest dates we have being September 25, 1913, and October 1, 1872.

The Vesper Sparrow is an abundant bird in the open parts of the County, and should be found in the open spaces in the mountains up to at least 9,000 feet. Nests in May, an unusually early date being a nest found by Warren near Colorado Springs, May 5, 1904, which contained 3 eggs. The nest is, always on the ground, often in a depression, and usually hidden under a tuft of grass, a bunch of weeds, or a low bush.

Passerculus sandwichensis alaudinus. Western Savannah Sparrow.

Summer resident above 7,000 feet; common. Most of 
them arrive the last of April and early in May, an extremely early date being March 19, 1899. They begin to move south the last of July, and are all gone by the middle of October.

In spring the Savannah Sparrow is found around meadows and marshy places, taking refuge in old dead weeds when disturbed, and is quite apt to be about alfalfa fields during May and to June first. In the autumn it is around weedy fields and grassy places. Before June first most of them go into the mountains and northward, breeding in this County from 7,000 to 9,000 feet. It has not been found breeding along the Fountain. A pair seen near Ramah in June appeared to be getting ready to nest. The nest is placed on the ground, well hidden in the grass.

\section{Ammodramus bairdi. Baird's Sparrow.}

Migrant, but rare in spring, there being but one record for that season, May 6, 1873. Autumn records are more frequent, Aiken, in 1897, securing specimens at various dates from August 22 to October 13; in 1898 it appeared as early as August 10. Most of these specimens were taken about weedy fields near the Broadmoor Ranch south of Colorado Springs.

October 5, 1872, Aiken killed one on the prairie 11 miles east of Fountain which was practically a rediscovery of the species which had been unknown since Audubon first described it in 1844 from a specimen taken in eastern Montana, near old Fort Union. North Dakota. This specimen of Aiken's was described by him as a new species, Centronyx ochrocephalus, as it did not agree with the descriptions of any other sparrows known at that time, and as a matter of fact was in a different plumage from the bird described by Audubon. Mr. Robert Ridgway examined Aiken's bird and expressed the opinion that it was a new species.

It is found on the prairies and in fields, but never in brush or bushes, at least as observed in this region. 
Ammodramus savannarum bimaculatus. Western Grasshopper Sparrow.

A rare autumn migrant, not observed in spring. The only records for the County are specimens taken by Aiken at Ramah, July 15, 1898, and near Colorado Springs, July 20. 1898, and August 8 and September 24, 1897.

Chondestes grammacus strigatus. Western Lark Sparrow.

Summer resident; common. Arrives about first week in May, April, 17, 1907, being the earliest date. Departs in September, the latest date being September 25, 1913.

Common on the plains, and probably in the open parts of the Ute Pass region. It may raise two broods as young not long from the nest have been seen on different occasions in the first two weeks in August, which would be late for a single brood unless the first nest had been destroyed.

\section{Zonotrichia querula. Harris's Sparrow.}

Rare, but two records for the County, a female taken byAiken at Buttes, January 24, 1908, which was in company with Juncos and Tree Sparrows; and one seen by Lloyd Shaw and others in Monument Valley Park, February 14, 1914.

Zonotrichia leucophrys leucophrys. White-crowned Sparrow.

Summer resident in the mountains; common. Arrives about May 4. Allen and Brewster saw it April 24, 1882. It has been seen as late as October first at 9,500 feet, and Cctober 12 in Monument Valley Park.

Just about the time the Gambel's Sparrows are beginning to leave in the spring the White-crowns make their appearance, and are found along the lower streams for a month before they retire to the mountains for the breeding season. They were noted by Warren in Monument Valley Park as late as 
June 2, 1913, and Aiken saw 6, collecting one, at Ramah, June 4, 1898.

This species breeds exclusively in the mountains, probably few breeding below 9,000 feet, and from that elevation to above timberline. The nest is placed in low bushes of various kinds, often evergreens, and never very far above ground. Drew stated that in the San Juan Mountains it raised two broods, the first at the lower part of its range, and then a vertical migration was made to above timberline where the second brood was raised.

On a trip to Strickler Tunnel July 9-10, 1899, Liken found White-crowned Sparrows "abundant in willows above timberine, and in the cañon below Seven Lakes, where birds were seen skulking among the low bushes, where they evidently had nests though they could not be found. The males mount to a top twig and watch the intruder quietly from a distance or utter a chirp of alarm on close approach. The song from near by may be represented by the syllables oo-dree-e-e, tw'ee-ty' too. Inhale the "oo" through the teeth and exhale the "dree" in higher key. Some times a low inhaling sound follows the effort. Birds above timberline were in. full song. Those lower down where nesting was probably further advanced were more quiet and skulking."

\section{Zonotrichia leucophrys gambeli. Gambel's Sparrow.}

Migrant; common in spring and autumn; a few winter. Arrives usually about the middle of March, February 27, 1899 , being the earliest date, and remains until the first week in May. May 11, 1898 is the latest spring date we have. The fall migration begins about the first of October, September 28,1907 , being the earliest date, and the majority have gone on by the early part of November.

While with us these birds frequent the brush along the streams and in the ravines, feeding on weed seeds and anything else they may find to their taste. Just before they leave in the 
spring they are often found in company with their relatives, the White-crowns, who have just arrived for the summer.

\section{Spizella monticola ochracea. Western Tree Sparrow.}

Winter resident; common. Arrives about the first of October, the earliest date being September 22, 1912. They begin to leave the last of February and early in April are nearly all gone. The latest spring date is one taken by Aiken, April 20, 1900.

The Tree Sparrow is one of our commonest winter birds, found everywhere about the bushy places of the foothills and plains, but does not go far into the mountains in winter. While it is often associated with various juncos, yet they seem disposed to keep somewhat apart, and when a mixed flock is disturbed the sparrows will often separate to a considerable cxtent from the others. In Monument Valley Park, the winters of 1911-12, many have patronized the food tables where millet and other seed is put out for them. Though they come to these tables in large numbers they are rather shy while there and will not permit a close approach. They are not entirely dependent on these tables, however, even in the park, and can be seen hunting food for themselves in the weeds and grass there, possibly for variety's sake. As their food is practically all seeds in winter, the Tree Sparrows and Juncos destroy great quantities of weed seeds during that season.

Spizella passerina arizonz. Western Chipping Sparrow.

Summer resident; common. Arrives April 10 to 20, the earliest dates being March 23, 1900 and March 24, 1899. Leaves in October, probably are about all gone by the 15 th; the latest fall date is October 24, 1897.

The Chipping Sparrow is one of our most abundant summer residents and breeders; nests in trees and bushes along streams and in gulches. Aiken noted a full fledged brood in Colorado Springs June 21, 1897; very likely two broods 
are raised in a season. The last of August and first of September they gather in large flocks, composed of adults and young of the year, the latter often hard to identify in the field, and are found about the brushy and weedy places everywhere. When the young are fledged and able to take care of themselves the males separate into little flocks by themselves and the females and young are in other flocks. The males migrate first, which is a common habit with various birds.

\section{Spizella pallida. Clay-colored Sparrow.}

Migrant; rather common on the plains. Arrives about the 7 th of May and found until about the 25th. It has been taken in the fall migration as early as July 25 th, and by the middle of September all have gone on.

Often found in flocks along the more open stream bottoms, and in weedy fields, avoiding the thickest brush; also found on the prairies.

Spizella breweri. Brewer's Sparrow.

Migrant; common; a few breed on the plains. Arrives about the first week in May, earliest date April.30, 1873 and 1898. The fall migration has passed by the middle of September.

Brewer's Sparrow probably breeds in small numbers in the County. Aiken found it July 14, 1897, at Ramah; June 25,1899 , at the Garden Ranch, where several pairs were breeding; and took a nestling near Colorado Springs, August 6. 1898, and also young in downy plumage August 22, 1897. Breeds in low bushes, apparently preferring sage brush and greasewood, of which there is but little in the County; here it is found about the scrubby bushes along outcropping rock ledges. Aiken recorded the song as $b \approx-z-z$ te-e-e-e-e-e.

Junco aikeni. White-winged Junco. Aiken's Junco.

Winter resident; common. Arrives the middle or latter 
part of October, the earliest date near Colorado Spring being October 20, 1911, and the last spring date being April 11, 1882, by Allen and Brewster, probably most of them are gone by April first.

Possibly this and the other Juncos go to the higher elevations on their first arrival in fall, for Lloyd Shaw reported seeing them in Jones Park, 9,000 feet, October 1, 1911.

This species varies considerably in abundance during different years, and some seasons it is not at all plenty; the winter of 1912-13 seemed to be an example of this. On the other hand the winter of 1909-10 it was unusually numerous : near Austin's Bluffs there seemed to be three times as many of this as of $J$. mearnsi as shown by speciments shot indiscriminately and field notes made at the time. The species seems to prefer the foothills and bulffs, and to keep away from the valley streams. It was found at Lake Moraine March 8 and 9, 1906. The first specimens of this species known to science were discovered by Aiken in Barnes's Cañon in December, 1871.

Junco hyemalis hyemalis. Slate-colored Junco.

Winter visitor, not common. Probably arrives and departs at the same time as the other Juncos. The latest spring date is April 25, 1899.

The rarest of our Juncos in winter but during a short period of autumn and spring migration quite common, sometimes in large flocks.

Junco hyemalis connectens. Intermediate Junco.

Winter resident; not common. Times of arrival and departure no doubt the same as the other Juncos.

About as common as hyemalis, shufeldti, and montanus, much more common in migration than in winter. 
Junco oreganus shufeldti. Shufeldt's Junco.

Winter resident; not common. Arrives and departs at the same time as the other Juncos, extremes being October 15 and April 10.

For the names of this and the two following species we follow Ridgway rather than the A. O. U. Check-List as it seems to us that the treatment of the Juncos in the latter is exceedingly unsatisfactory.

Shufeldt's Junco is not uncommon during the winter but is not found in any such numbers as the Pink-sided or Grayheaded Juncos, or even the White-winged in its abundant seasons. In the field, without the use of a glass, it is often difficult to distinguish between this and the Intermediate and Montana Juncos, except when one is very close. At a near view, the very black head and pink sides of the Shufeldt's make it easily identified, but the females are difficult if not impossible. As a writer in Bird Lore says:

"For the female of the species is more puzzlin' than the male."

Warren took one at Lake Moraine in December, 1906, and a black-headed Junco of some sort was seen there in March, 1906.

In migration this species is quite common.

Junco montanus. Montana Junco.

Winter resident; not common. Arrives and departs at much the same times as the other Juncos.

There are seven specimens in the Aiken Collection taken at various date from October 25 to April 24. This is probably the least common of our Juncos in Winter; in the migrations it is more abundant. The males arrive from the south about February 25 and are around for ten days or more, and the females follow somewhat later in March. 
Junco mearnsi. Pink-sided Junco.

Winter resident; common. Arrives early in October. possibly usually not until the second week; earliest record September 30, 1913. Departs in April, lingering longer than either of the Juncos previously mentioned. Latest date May $4,1872$.

The most numerous of the Juncos, and usually forming the greater proportion of the flocks one meets with, but in the winter does not usually go high into the mountains, keeping more to the foothills and plains. It is always to be found in Monument Valley Park in winter with the flocks of Tree Sparrows. Possibly the reason they stay later in spring than the other species is that they have not so far to go to reach their breeding grounds, as many spend the summer ir. Wyoming.

Junco phæonotus caniceps. Gray-headed Junco.

Resident; common.

This, our resident Junco, breeds commonly in the mountains down to 7,500 feet. It spends the winter in the foothills and on the plains in varying numbers, but it is safe to say that at that season it is always outnumbered by the Pinksided Junco, and frequently by the White-winged. It prefers the foothills to the plains. Sometimes flocks of Juncos are seen which contain a large percentage of this form; one goodsized flock seen by Warren on Bear Creek near the mouth of the cañon, November 18 and 20,1912, seemed to be fully one half of this species, the rest Pink-sided; usually the proportion is much smaller. Ordinarily but one or two at a time are seen in Monument Valley Park. The majority of our summer birds probably go south in winter, many of the winter residents coming from other localities.

The nest is built on the ground, sometimes in a cavity in a roadside bank or a stream bank. One found by Rockwell 
and Warren in Jefferson County was sunken in the ground so that the rim was flush with the surface. The nest proper was made of grass, coarse outside, lined with finer, with a few horsehairs intermingled. This was under a Douglas's fir tree, and nearly covered by a spreading branch which grew out almost at the foot of the tree and actually rested on the ground over the nest. This nest contained four fresh eggs and is now in the Colorado College Museum. Taken May 30, 1912.

July 10, 1899, Aiken found a nest with five young a week old at the Strickler Tunnel, 11,500 feet. The first nest of the species known to science was found by Aiken, and the description was published in 1875 .

Aiken took two of the birds at Ramah, May 16, 1904, a rather late spring record for the plains. One was also taken May 16, 1908, at Buttes.

Melospiza melodia montana. Mountain Song Sparrow.

Summer resident; not common. A good many spend the winter, and it is abundant in migration. The spring migration seems to begin about March first, and in fall most of the birds have gone on by the last of October.

As a winter resident the Song Sparrow is no doubt irregular. November 8, 1897, Aiken took two on Fountain Creek; the 22 nd he took three and saw about a dozen; they were not found December 6th following at the same place. At Skinner's, January 15, 1908, he took 3 and saw 20. At Buttes, January 24, 1908, many were seen. There is a skin in the Aiken Collection taken February 6, 1873.

Warren took one on each of the following dates: December 4, 1882, December 12 and 14, 1883. One was seen February 23 and 24, 1913, in Monument Valley Park and also later on in March. November 17, 1912, two or three were seen in the I'ark, and seemed to hold themselves aloof from the numerous Tree Sparrows. December 22, 1912, one was also seen there. 
December 8,24 , and 28,1913 , after the unusually heavy snowstorm of that year, one or two were seen in the Park.

Certain specimens from this region have been identified as M. m. melodia, but are not typical.

Melospiza melodia juddi. Dakota Song Sparrow.

A Song Sparrow taken by Aiken near Colorado Springs, March 20, 1898, has recently been identified by H. C. Oberholser of the Biological Survey as Melospiza melodia juddi. This is the first record of this subspecies for Colorado.

Melospiza lincolni lincolni. Lincoln's Sparrow.

Summer resident in the mountains; common. Arrives in April, there being a considerable variation in the first arrival dates, from April 9, 1899 to April 30, 1898. Near Colorado Springs the migration lasts until the middle of May, and June 4-7, 1898, Aiken found it at Ramah, still migrating. A pair was noted south of Colorado Springs the first week in June, 1897.

Lincoln's Sparrow breeds in the mountains, from 8,500 feet possibly to timberline, though we have no exact information as to the upper limit of its breeding range. It prefers the willow thickets in the mountain parks.

Melospiza georgiana. Swamp Sparrow.

Rare, but one occurrence known in the County, a bird seen near Broadmoor Ranch by Aiken, August 8, 1897.

Pipilo maculatus arcticus. Arctic Towhee.

Winter resident; not uncommon. Earliest autumn date, Novémber 11, 1909; latest spring date, May 12, 1878.

Most of out winter towhees are probably the Arctic Towhee. They are found usually about the oak thickets at the lower edge of the foothills and in the bluffs, industriously 
scratching among the leaves for whatever they can find in the way of food.

Pipilo maculatus montanus. Mountain Towhee.

Summer resident; common. Winter resident; rare. The spring migration seems to begin early in April and is in full swing by May 1. Most of the birds are gone by the last of October.

A few individuals of this species spend the winter with us, just how many it would be difficult to say without collecting every Towhee one sees. The following are winter dates of specimens from the County identified by Oberholser: January 16, 1910; March 12, 1877 ; December 13, 1909. There is also one taken March 28, 1878, which might be either a winter resident or an early spring arrival.

- A common breeder up to above 7,000 feet frequenting very largely the oak thickets in the foothills, bluffs, and mesa gulches. Aiken found a nest with four eggs May 29, 1872. A pair probably bred in the Monument Valley Park in 1913.

\section{Pipilo fuscus mesoleucus. Cañon Towhee.}

Rare; there are a few pairs locally distributed along the lower edge of the foothills. A specimen in the Aiken Collection was taken at Red Rock Cañon, April 13, 1878. The winter of 1907-8 one or two were constantly seen on Camp Creek, not far from Colorado City. Usually but one was seen, but Aiken saw two January 29.

Oreospiza chlorura. Green-tailed Towhee.

Summer resident; common. Arrives about May 1 ; earliest date April 27, and by May 7th the species is here in full force. It appears to be all gone by October 1 .

This species is most numerous in migration, probably comparatively few breed below 7,000 feet. A pair no doubt 
bred in Monument Valley Park in 1913 as they were seen constantly about a certain dense thicket during May and into early June, and July 27 one was seen at the same place. At least two males were seen courting their mates in the park in May and their actions are interesting and differ from their ordinary habits. Instead of skulking in the brush and dodging out of sight when an intruder appears, the bird perches in a tree, spreads its tail out into a fan, and erects the feathers on the head until the red cap makes quite a respectable little crest, and sings its love song. While the bird is thus engaged one can approach quite closely. "Its call note is pé-a-wée, rather weak, and with something of the cat-like mewing tone of the Catbird. Its song is one of the finest of the finches, resembling the thrushes in variety, modulation and sweetness, but lacking in volume." C. E. A., ms. notes.

This Towhee wanders to considerable elevations, breeds to 9,000 feet, perhaps more. Aiken noted it at the Strickler Tunnel and Seven Lakes, July 9-10, 1899; Warren saw it at Lake Moraine August 30, 1905.

Zamelodia melanocephala. Black-headed Grosbeak.

Summer resident; common. Arrives about May 10. Are all gone by September 1. Found commonly in thickets along streams in the foothills and along the valleys; probably does not go much above 7,000 feet. Breeds early in June, though 11esting may continue through the month. Aiken found a nest with three eggs near Colorado Springs, June 19, 1898, and three nests near completion the same day. Young of the year are common by August first. A female was sitting on eggs near lvywild, June 3, 1913.

A Black-headed Brosbeak kept in a cage for 8 years by a Mr. Feets of Colorado Springs took on a peculiar plumage in the last year. Aiken went to see it July 21, 1899 and notes as follows:

"The upper. parts are wholly black. Beneath it is of the 
Plate XXI.

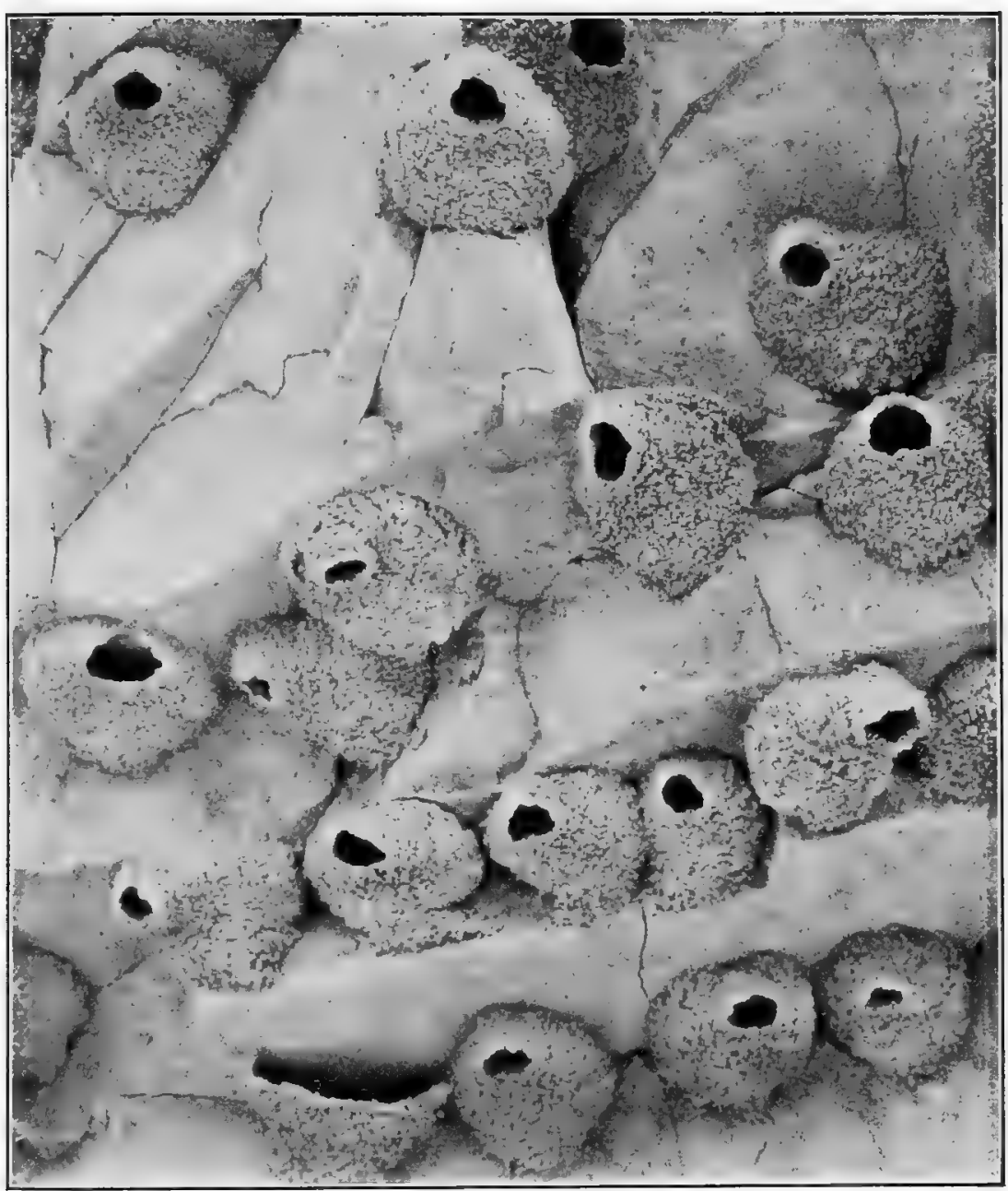

Fig. 39.

E. R. II., Photo.

Cliff Swallows' Nests.

A part of the colony shown in Fig. 38. 
Plate XXII.

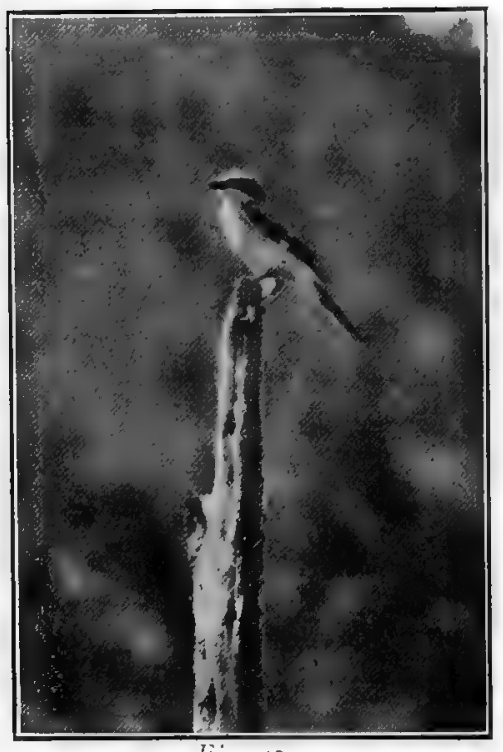

Fig. 40.

White-Rumped SHRIKe.

E. R, W., Photo.

Garfield County, Colo.

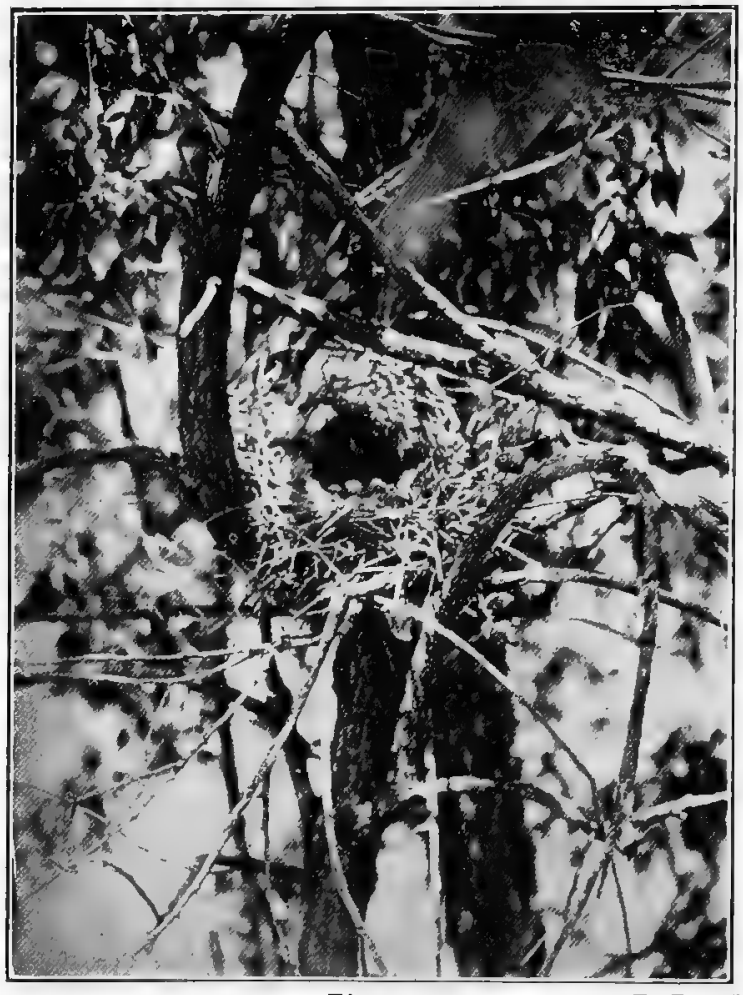

Fig. 4 I.

E. R. W. Photo.

White-Rumped Shrike's Nest. Elbert County, Colo. 
normal autumnal shade of brownish red, but this color is obscured or hidden by sooty black tips to the feathers. The general effect is that of a black bird." The bird died late that autumn.

Guiraca cærulea lazula. Western Blue Grosbeak.

Summer resident; not common. Arrives about June 1.

There are comparatively few records of the Blue Grosbeak for El Paso County ; it has been taken or observed at Colorado Springs, Skinner's, Fountain and Buttes at intervals from 1872 up to the present time, and the dates run from June 1 to August 13, nearly all being June occurrences.

Passerina cyanea. Indigo Bunting.

Rare; but one record for the County, a male taken by Aiken May 8, 1872, at his ranch on Turkey Creek.

Passerina amcena. Lazuli Bunting.

Summer resident; common. Arrives about the first week in May; departs in August and September.

This beautiful bird is quite common in the brush along the streams; a number seem to spend the summer in Monument Valley Park, where one day three of the brightly clad males were seen on a food table. Aiken found, June 19, 1898, in rose bushes on a hillside near Bear Creek a nest of this species containing 3 eggs and one Cowbird's egg. He notes the song of one bird heard as tsup, tsup, tsip,-tsip,-tsip, uttered in loud clear tone and repeated at intervals of a minute or so. The vertical range of this bird extends but little if any above 7,000 feet.

\section{Spiza americana. Dickcissel.}

There is a single specimen of this bird in the Aiken Collection, a male taken at Broadmoor Ranch, August 29, 1897. 
Allen says that in 1871 it was "Frequent near Colorado City." This statement seems rather odd in view of the fact that the above mentioned specimen is the only one seen or taken in El Paso County since.

\section{Calamospiza melanocorys. Lark Bunting.}

Summer resident; common. Arrives usually early in May, about the 10th. It was reported by Scheutze April 10, 1910, and by Shaw April 15, 1912. Leaves in September.

A bird of the plains and open country, nesting on the ground, laying 4 or 5 unspotted pale blue eggs. When first arrived they are in flocks, the males paying active court to the gentler sex, and singing continually. In western Kansas Aiken found Lark Buntings very numerous and the notes on their habit of singing on the wing apply so well to them in Colorado they may well be quoted here: "The males are singing almost incessantly from daylight until 7 or 8 o'clock, and frequently throughout the day. They frequent open prairie without brush, but prefer cultivated districts where there is an early growth of weeds and grass. The male mounts into the air at an angle of about 60 degrees to the height of 15 or 20 feet, gives two or three broad flaps of his wings as he steadies, and then floats off to the ground, alighting 15 or 20 yards from where he started, and singing continuously, in one key as he rises, in another as he floats downward. Looking out over the prairie one see them in their conspicuous black-and-white dress going through this performance as far as the eye can discern.

At this time of the day (morning) females are not seen being probably on their nests, but during the heat of the day they are seen feeding along the road or making short low flights." This was May 24, 1900. He found full-fledged young at Ramah July 15, 1897. 
Piranga ludoviciana. Western Tanager. "Louisiana Tanager."

Summer resident; common. Arrives May 10-15. Begins to leave early in September, but has been taken as late as the middle of October.

The Tanagers arrive from the south in small flocks of from 3 or 4 to 7 or 8 , and in migration are found well out on the plains. While the majority pass on a good number remain to breed. They are largely birds of the foothills and the Divide, probably not breeding much above 8,000 feet, though Aiken saw one in the neighborhood of St. Peter"s Dome, 8,700 feet, July 4, 1907. In summer they are confined almost exclusively to the pines. Keyser speaks of finding a nest in a pine tree at the entrance of Engelmann's Cañon near Manitou. While often seen in Monument Valley Park in May it probably does not breed there, not having been observed in the summer months. Aiken notes the call as clit-ic or crit'-ic, uttered at intervals of one or two seconds.

Piranga erythromelas. Scarlet Tanager.

Rare. One was taken at Palmer Lake, May 17, 1902, by W. C. Ferrill. J. A. Jeancon reported seeing a considerable number at Palmer Lake, May 16 and 17, 1909, during a severe snowstorm.

Petrochelidon lunifrons lunifrons. Cliff Swallow. Eave Swallow.

Summer resident; common. Arrives the middle of May; leaves the last of August or early in September.

This species reaches a high altitude, at least in its search for insects, for it has been observed to above 13,000 feet. One of our most common swallows. It breeds in colonies about cliffs and buildings, on the latter under the eaves. 
Hirundo erythrogastra. Barn Swallow.

Summer resident; not numerous. Usually arrives about May 1; has been seen as early as April 20, 1899. Departs the last of August or early in September.

Found over much of the County, but not nearly as common as the Cliff or Violet Green Swallows; perhaps the fourth in abundance of our swallows. Like the others it wanders above timberline in pursuit of insects.

Iridoprocne bicolor. Tree Swallow.

Summer resident; rare.

Allen noted a pair nesting in June on West Monument Creek. One of the rarest of our swallows, only a few seen. Aiken has noted a breeding colony at Divide Station, Teller County.

Tachycineta thalassina lepida. Violet-green Swallow.

Summer resident; common. Arrives about May 1; April 23, 1899, being the earliest date. Departs about September 1. Wetmore took two at Palmer Lake September 5, 1909.

This is the most abundant of our swallows; it seems to breed mostly in the mountains and foothills, nesting in hollow trees, and often using old woodpecker's holes. Allen noted it breeding in holes in the rocks at the Garden of the Gods in 1871 , and the birds still continue to breed abundantly there. Like the other swallows in August the Violet-green begins to gather in flocks preparatory to the departure for winter quarters. For days we see them congregated on the telegraph and telephone wires, then some day they are gone and not seen again until the next spring.

Riparia riparia. Bank Swallow. Sand Martin.

Rare; Aiken mentions seeing it April 26, 1872. There are no records of its breeding in the County. 
Stelgidopteryx serripennis. Rough-winged Swallow.

Summer resident; common. Arrives about May 10; departs with the other species.

This species, while fairly common, is somewhat locally distributed in the breeding season, owing to the comparative lack of suitable nesting sites. Full-fledged young of the year were taken along Monument Creek, north of Roswell, July 23, 1899, by Aiken.

\section{Bombycilla garrula. Bohemian Waxwing.}

I'inter visitor; irregular; not seen at all many winters.

The first note we have of this species is January, 1872. when . Aiken saw a flock in Barnes's Cañon, near Turkey Creek, and a note that Carter killed one on Pike's Peak the fall of 1871.

There are specimens in the Aiken Collection taken on Cheyenne Mountain, January and February, 1880. There were some around the winter of $1910-11$, and they were in Colorado Springs, February 26, 1911.

Aiken noted at Salt Lake City, Utah, in 1895, that in the late afternoon the Waxwings, which had been about neglected crchards near the town feeding on the apples still hanging to the trees, began to fly in flocks up the cañons toward the mountains, evidently going to their roosting places in the green timber.

Bombycilla cedrorum. Cedar Waxwing.

"Noticed only two or three times and in the earlier part of the winter." Aiken List, 1872. 5 or 6 seen on Beaver Creek by Aiken, October 17, 1872. This was just over the line into Fremont County. Several were also seen by him just south of Colorado Springs, August 8, 1897. 


\section{Lanius borealis. Northern Shrike.}

Winter visitor; common. Earliest date of arrival, October 17, 1874 ; latest spring date, April 9, 1899.

When one speaks of the Shrike as common it is not that they are so numerous, but because, though individually few, there are always some with us through the winter. It is usually to be seen perched on a tree or post, near brush frequently by sparrows or juncos, watching for a chance to get a meal. No doubt the bird also picks up a few mice, and an occasional insect. Aiken shot one flying with a large field mouse in its claws. One was seen in Monument Valley Park one November day tormenting a Magpie much as a Kingbird would. The Magpie was perched in a tree and the Shrike would fly at it and make it move to another place, and repeated these tactics until "Maggie" got disgusted and went away altogether. This Shrike was about the park from October 20 until November 17, 1912. A male was seen singing in the park November 1, 1913.

At Ramah, in March, 1899, Aiken saw this Shrike carry away a Horned Lark which he had just shot and killed. The Shrike pounced upon the lark and seized it by each shoulder with its feet, and then rose into the air and flew off with it against an exceedingly strong wind, the lark being held so that its wings were outspread beneath the body of its captor; thus helping to lift or support itself in the air.

\section{Lanius ludovicianus excubitorides. White-rumped Shrike.}

Summer resident; common. Rather irregular in arrival in spring, from March 30 to May 1, probably most of them come from the middle to the latter part of April. Most of them have left by October first, but a few linger somewhat later.

Mostly a bird of the plains and foothills, but at times ranges high in the mountains. Aiken once noted it above timberline at the head of Tennessee Gulch, Lake County. 
This Shrike builds a bulky nest of small sticks, lined with wool and other soft material. Aiken found two nests at Ramah with 7 eggs in each, June 4-7, 1898. He saw old birds feeding young with grasshoppers at the same place, July 15 , 1897, at which time 30 adults and young were seen. These birds are great destroyers of grasshoppers and other insects and probably do not kill as many birds as the larger species, though their actions and habits are in many respects the same. Scheutze reported seeing a pure albino of this species May 1, 1904 , on the plains east of Colorado Springs. A Shrike with black crown was killed and mounted by the same party about June 1, 1907, but before it had been critically examined it was destroyed by a cat.

In reference to the black-headed Shrike Prof. Wells W. Cooke writes:

"There are about six species of shrikes in the world which have a black crown, but they are all African species, and since they are non-migratory the only way one of them could have gotten to Colorado would be as an escaped cage bird. So far as I know there is no European species of shrike that has the crown black; their shrikes are closely related to ours."

\section{Vireosylva gilva swainșoni. Western Warbling Vireo.} Swainson's Vireo.

Summer resident; common. Arrives about May 15 to 25 ; departs the last of August and early in September.

Breeds on the plains and in the mountains; Aiken noted it near St. Peter's Dome, and Keyser at Lake Moraine. Breeds in the trees near the streams, building a semi-pensile nest like other vireos on the lower branches. Aiken found a nest in Monument Valley Park in June, 1907. 


\section{Lanivireo solitarius cassini. Cassin's Vireo.}

Rare; one taken at Palmer Lake, September 6, 1909, by Alex. Wetmore.

Lanivireo solitarius plumbeus. Plumbeous Vireo.

Summer resident; common. Arrives about May 16; departs early in September.

Frequents park-like areas with scattered pine, from the foothills to 9,000 feet. Aiken noted it at St. Peter's Dome July 4, 1907. Common on the Divide and along the foothills. On Turkey Creek he found the nests in small second growth pines, some as low as four feet from the ground. It has been found breeding on Cheyenne Creek at Ivywild.

Mniotilta varia. Black and White Warbler.

A single specimen of this warbler was taken by Aiken on Turkey Creek in the autumn of 1875 , the only record for the County.

Protonotaria citrea. Prothonotary Warbler.

Rare; but one record for the County, a specimen taken between Palmer Lake and Monument, May or June, 1900, by B. G. Voigt, and recorded by Felger, Auk, XXIV, July, 1907, p. 342. Aiken has visited the locality indicated and found an extensive willow thicket flooded by beaver dams, producing quite suitable conditions for this species.

Vermivora virginiæ. Virginia's Warbler.

Summer resident; common. Arrives in May, earliest date May 2, 1872; most numerous about the 15th. Departs the last of August and early in September. At Palmer Lake, September 6,1909 , Wetmore took three and saw others.

A bird of the foothills, ranging in the breeding season to about 8,000 feet. In migration, especially in spring, it is 
abundant along the valley streams in the trees and bushes. The males come first, but their mates are not long in following, and Aiken took a mated pair May 21, 1898, near Colorado City. It is a characteristic warbler of the foothills, and perhaps the most abundant of this group of birds in these localities. The first nest of this species known to science was found and described by Aiken. This was sunk in the ground in a tuft of bunch grass growing in a clump of oak brush, with the dead grass hanging over and completely concealing the nest, which was reached through a small round hole like a mouse hole through the protecting grass. This nest contained five fresh eggs, and was found about June 1, 1873. The species seems to nest exclusively about the oak brush.

Vermivora celata celata. Orange-crowned Warbler.

Common in migration. Arrives the very last of April, having been observed on the 27 th and 28 th of that month in different years.

This warbler is common about the trees and bushes of the valley streams and in the foothills during the first half of May, and is one of the very earliest of the warblers to arrive in spring, but there are no breeding records for this County. If Oberholser's subspecies orestera had been allowed by the A. O. U. our birds would belong to it, being intermediate in characters between celata and lutescens.

Vermivora peregrina. Tennessee Warbler.

Rare; but one record for the County, a juvenile male taken by Aiken, September 28, 1872. Aiken has found several near Limon, some distance easterly from our limits, and it is undoubtedly a regular migrant in the eastern parts of Colorado.

Compsothlypis americana usneæ. Northern Parula Warbler.

Rare, but one record for E1 Paso County, a male taken by Aiken, May 11, 1872, on Turkey Creek. 
June 14, 1897, and for six successive days after that, Aiken observed in the top of tall cottonwoods at his home in Colorado .Springs in the early morning a small grayish-olive warbler, with a conspicuous white band on the wing, which it seems must have been a Parula Warbler. It was seen again July 7 ; it is presumed to have had a nest in the neighborhood.

\section{Dendroica æstiva æstiva. Yellow Warbler.}

Summer resident; common. Begins to arrive the first week in May, the majority coming in the second week. Departs early in September.

This species is common almost everywhere in the County, at least where there is any sort of tree or brushy growth, and ranging up to above 9,000 feet. It builds its nest in the low bushes and thickets along the streams. Aiken found a nest with three eggs and one of the Cowbird near Bear Creek, June 17, 1898. June 3, 1913, a nest with 4 eggs was found near Ivywild. lt is one of the most common summer birds in Monument Valley Park. Many of our breeding birds are very pale and several skins submitted to $\mathrm{Mr}$. Brewster were pronounced by him to be "nearly typical sonorana."

Dendroica coronata. Myrtle Warbler.

Migrant; not common. Arrives about May 1; earliest date April 17, 1907. There do not seem to be any autumn records.

Dendroica auduboni. Audubon's Warbler.

Summer resident in the mountains; common. Arrives the last of April and soon becomes abundant; the earliest record is April 16, 1872. Departs the last of September, the latest date being October 2, 1913.

This species breeds commonly in the mountains from about 8,000 feet to nearly 12,000 feet. Minot found a nest of the Audubon's Warbler at Seven Lakes, June 24, 1880, which he 
describes as follows: "June 24, [1880] at Seven Lakes, I found four eggs almost ready to be hatched. These are curiously like a common type of the Yellow Warbler's, being greenish white, marked, chiefly about the crown, with olive brown and neutral tint and averaging about .70x.55 of an inch. The nest, composed of shreds and feathers, was built in a dead bare spruce, about twenty feet from the ground, compressed between the trunk and a piece of bark that was attached beneath and upheld above, where a bough ran through a knothole; so compressed that the hollow measures $2 \frac{1}{4} \times 13 / 4$ and 11-3 inches deep. Such a position for the nest is not unusual, for I more than once saw the birds about dead timber."

Audubon's Warblers are usually common in the trees and bushes along the streams on the plains and in the foothills in the spring from their first arrival until the middle or latter part of May. A late valley record is one taken June 5, 1904, at Fountain, by Aiken. On the whole it is the most common warbler we have.

Dendroica striata. Black-poll Warbler.

Migrant; rare. The only records are of spring birds. Allen and Brewster noted it May 8 and 9, 1882, at Austin's Bluffs. Aiken took one May 18, 1872, on Turkey Creek; May 8, 1904, at Fountain; June 1, 1907, at Skinner's.

Minot, 1880, recorded it as "local summer resident about Seven Lakes." This record is open to question. Minot collected no specimens, and the locality is so far south of any other known breeding station of the species that the record had best be disregarded until substantiated by specimens actually taken.

Dendroica nigrescens. Black-throated Gray Warbler.

Local summer resident. Arrives about the first week in Maý, Aiken having taken his first specimen May 6, 1872.

As far as we know this species is confined in El Paso 
County to the piñon and cedar region in the southwest corner, where they were observed all through the summers of 1872-73

Seiurus aurocapillus. Oven-bird.

Rare; but one record for the County, a female with ovaries well developed taken by Aiken at Ramah June 5, 1898. With one exception this is the only Colorado rccord.

Oporornis tolmiei. MacGillivray's Warbler.

Summer resident; common. Arrives the first or second week in May. Departs in September.

Breeds along creek bottoms from the lowest edge of the foothills and in the mountains up to above 9,000 feet. Shaw found it common in Crystal Park at 8,500 feet. It is common along the plains streams in the spring migration, and Aiken found it at Ramah, June 6,1898 , where it was very common as a migrant.

Geothlypis trichas occidentalis. Western Yellow-throat.

Summer resident; common. Arrives usually the first week in May; early records are April 13, 1882, and April 17. 1907. Departs in August and early September. The latest date is September 17, 1897.

Frequents the neighborhood of streams and ponds on the plains and along the foothills, rarely going above 8,000 feet, and breeding in damp thickets and swampy places. Aiken took a female near Bear Zreek, July 25, 1897, which had an egg in the ovary. He noted a pair in Manitou Park, 8,500 feet, in June, 1905.

\section{Icteria virens longicauda. Long-tailed Chat.}

Summer resident; common. Arrives the first week in May. Leaves in September; latest date September 8, 1897.

Breeds along the valley streams to the foothills, but does 
not penetrate into the mountains. A shy and elusive bird, though its song is continually heard in the early summer months. Olive Thorne Miller mentions finding a nest with three eggs near Camp Harding, on Cheyenne Creek; and Aiken mentions in notes young hatched June 25, 1872.

\section{Wilsonia pusilla pileolata. Pileolated Warbler.}

Summer resident in the mountains; common. Arrives about May 14. Leaves in September, latest date October 13, 1912.

This species is the western representative of the Wilson's Varbler. It is rather common during the spring migration in the thickets along the streams, found out on the plains as well as near the mountains, remaining until the last of May, but retires to the mountains to breed, and sometimes breeds in the Alpine willows above timberline. Minot found a nest at Seven Lakes which he describes as follows: "Here, June 22, [1880] I found a nest five fresh eggs. The nest was sunken in the ground, on the eastern slope or border of the swamp, at the end of a partly natural archway of long"dry grass, opening to the southward, beneath the low, spreading branch of a willow. It is composed of loose shreds, with a nest lining of fine stalks and a few hairs, and with a hollow two inches wide and scarcely half as deep."

\section{Setophaga ruticilla. Redstart.}

Rare; not many records. Dates of arrival are May 17, 1905 ; May 14, 1898 ; May 18, 1882 ; May 21, 1872.

Allen saw it at Colorado City in 1871 ; he was there early in August. Almost all the birds which Aiken has taken or seen here have been immature males, in the plumage of the second year, and but one full plumaged male has been taken. There are no breeding records for the County. 


\section{Anthus rubescens. Pipit.}

Summer resident at high elevations; common. Arrives on the plains the last of April and departs the last of September.

The Pipits breed mainly above timberline on the open grassy slopes, placing the nest in a hollow in the ground, often protected by a tuft of grass. They, however, in some instances breed below timberline on open ground. Aiken observed Pipits just below the lowest of the Seven Lakes in June. In migration this species often occurs on the plains in large flocks.

\section{Cinclus mexicanus unicolor. Water Ousel. Dipper.}

Resident on the streams in the mountains; not uncommon. In winter a few come somewhat lower down along the streams, outside the foothills.

Water Ousels are interesting birds, and if one takes into consideration the fact that the species apparently numbers but comparatively few individuals, might be termed common. It prefers the rapid mountain streams for a residence and only in winter does it come out of the foothills, and but few of the birds do this, most of them stay in the mountains the year round, always finging a little open water even in the coldest weather. It is regularly seen in winter in Ruxton Creek just below Lake Moraine, at 10,000 feet. One December afternoon I was there, it was cold and windy and I was resting in a sheltered place close to the creek, which had much fall at that place. An 'Ousel came to a rock a few feet away; the bird was down below the rushing water which splashed on it continually, and the rock was wet and slippery, but the Ousel did not mind a bit. Once it was down on a little twig which was just out of the water and all wet; it looked like a cold place to me, and I wondered how those delicate little feet could possibly keep from freezing. Then the bird flew upon the wet rock again and began to sing, and after singing a little there went to another rock and stood there bobbing and 
singing away. (E. R. W.) The song is sweet and thrush-like, and heard under such conditions it sounds especially sweet.

The food consists mostly of aquatic insects, and one killed on Fountain Creek, near Colorado City, December 1, 1882, had a small fish in its stomach, too much digested to be identified.

The nest is a rounded mass of the green moss from the rocks along the stream, placed on or under a ledge of rock, often beneath a waterfall, and always near the water. Keyser mentions a nest with two young near Rainbow Falls, Ute Pass, and another nest found farther up the Pass. A nest was also found in South Cheyenne Cañon, near the lower of the Seven Falls. The nest under Rainbow Falls was occupied annually for many years, until the falls were destroyed by a cloudburst which washed away the rocks forming them. Olive Thorne Miller saw an adult in South Cheyenne Cañon feeding a young bird large enough to be out of the nest.

Near Rainbow Falls Aiken was once able to observe closely an Ousel feeding in the water. He says: "As I walked down the Ute Pass road I looked into the gorge below Rainbow Falls and saw a Water Ousel at the shore of the stream repeatedly dip into the water and return to rest on a certain stone at the water's edge. Its "actions were unusual; I had noticed nothing like it before and was curious to observe more closely. So taking advantage of the moments when the bird was beneath the water I moved toward the spot and when it came to the surface I stood motionless. In this way I reached the stream and stood within two feet of the Ousel's perch without alarming him. He merely cocked his head and looked up curiously but gave me no further attention.

The stream at this place dashes noisily over rocks and boulders but on this side was a quiet pool. This was three feet or more across and seven or eight inches deep with a clean sandy bottom which was distinctly seen through the clear water, as were also circling fragments of drift brought 
in by an eddy from the stream. When the Ousel was ready to go into the water it dove in head first and lit on the bottom of the pool where it walked or ran about as if on dry ground. It chased and seized in its beak certain small particles of the drift that were perhaps water insects or insect larvæ. The time spent under water was some seconds, perhaps a minute. When he was ready to come out for breath he walked over to his resting place, popped to the surface of the water like a bit of cork and stepped out perfectly dry onto the stone.

What a remarkable provision of Nature is this which enables a little song bird to float without effort upon the water's surface, or to sink at will and walk securely along. the bottom beneath! The explanation, however, is not difficult. Its body plumage is long, dense, and impervious to watcr. Under ordinary circumstances, and particularly if floating, the feathers stand out loosely from the body and the outward bulk of the bird is great in proportion to its weight. Its bulk is lighter than the same bulk of water and it floats. But if its plumage and wings are tightly pressed against the body excluding all air, the bulk is reduced so that its weight is greater than the same bulk of water and the bird sinks."

Oreoscoptes montanus. Săge Thrasher. Mountain Mockingbird.

Migrant; not common. Arrives early in April, from the 7 th to the 15 th. There are no breeding records. The only autumn date we have, if it can be called such, is one seen by Aiken six miles north of Colorado Springs, July 25, 1898.

This bird is not at all common in El Paso County, and is only seen during migration. In the breeding season it inhabits the greasewood and sage brush plains, of which there are none in the County. An occasional bird may be seen at the time of the spring snowstorms when they are driven from. the mountains. 
Plate XXIII

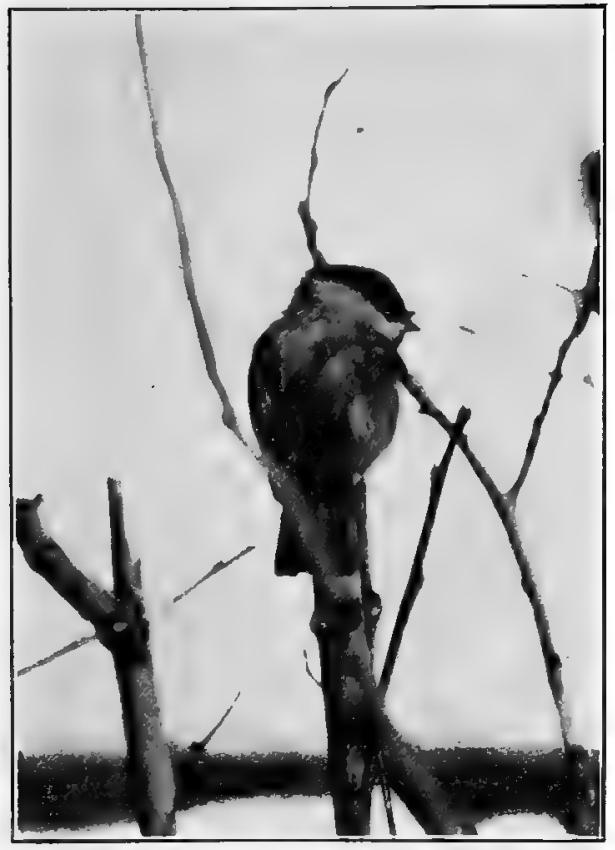

Fig. 12.

Long-Tailed Chickadee.

Bison Reservoir, Teller County, Colo.

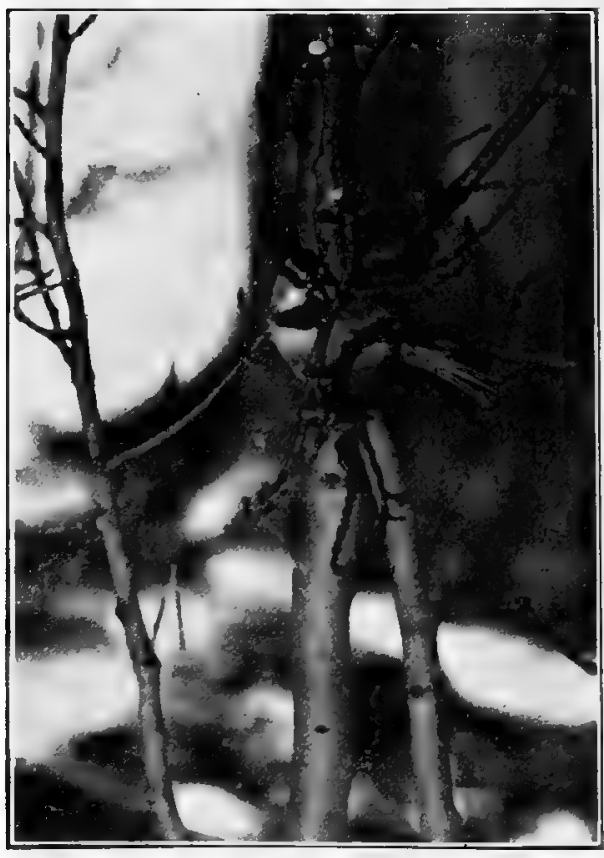

IFig. t3. E. R. W., Photo. Mountain Chickadee.

Bison Reservoir, Teller County, Colo. 
Plate XXIV.

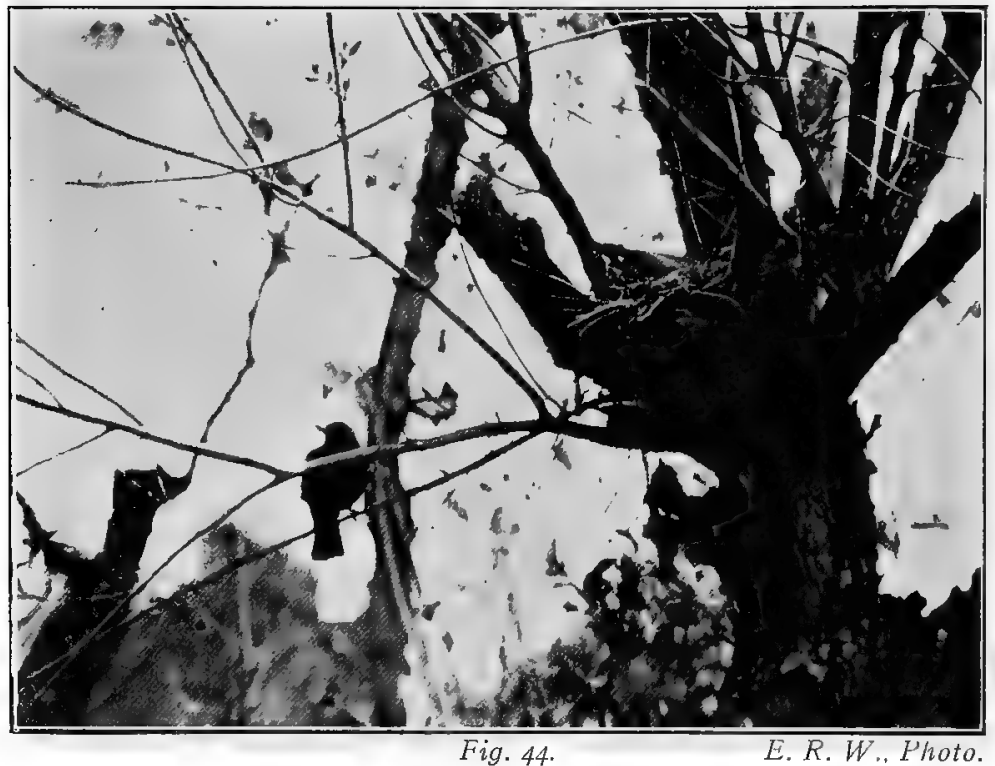

Robins and Nest.

Colorado Springs.

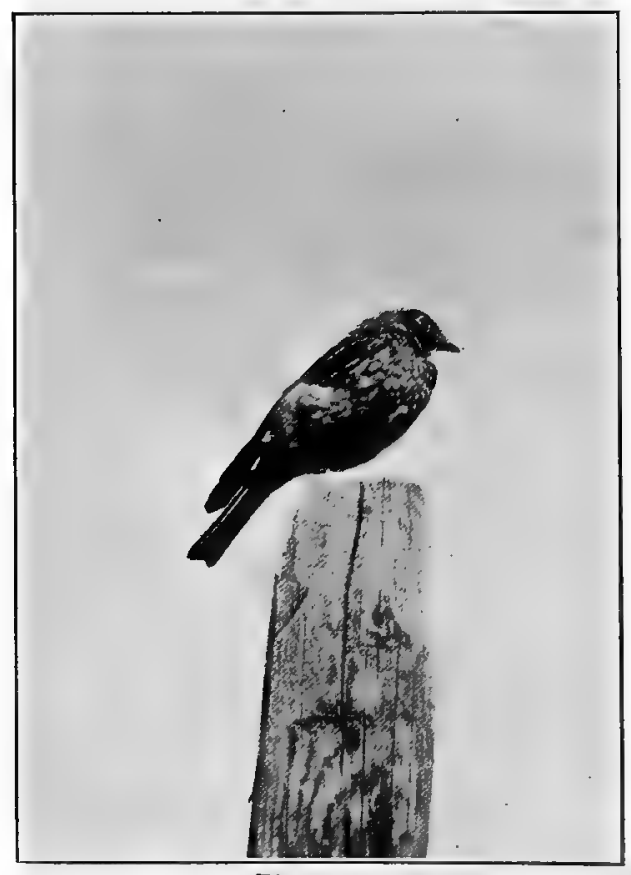

Fig. 45.

E. R. W., Photo.

Young Mountain Bluebird.

North Park, Colo. 
Mimus polyglottos leucopterus. Western Mockingbird.

Summer resident; locally' distributed. Arrives the first week in May; earliest date April 26, 1882, Allen and Brewster.

Mockingbirds are locally common in E1 Paso County; in the Fountain Valley, toward the Pueblo County line, there are many and Aiken found them rather abundant at Ramah, where, June 4-7, 1898, he found two nests and eggs. Speaking of their habits, his note book says: "The female bird is retiring and noticeably browner. The male bird, on the contrary, is much in evidence, taking extended flights across the open country and from one part of a grove to another, conspicuous from his brighter color and large white wing patches."

A year previous to this he was told of a pair coming to a ranch on the open prairie east of Colorado Springs. The ranchman set some branches from pine trees in the ground and the birds nested in one of these. When the five young were well grown they were put in a cage and were fed there by the mother until they could take care of themselves. One escaped from the cage and was followed off by the male bird, but the female remained to feed the caged birds.

The species is rare at Colorado Springs; instances are known, however, of its breeding in the city. In 1904 a pair of Mockingbirds nested in a tree beside the street on Wood Avenue. Though the tree was but a small one its foliage was so dense that the nest could hardly be seen, and would be unnoticed by the casual passerby. The bird was seen on the nest June 17. I went away a day or two after and was absent most of the summer, but on my return was told that a brood had been successfully raised. The last of May and early part of June the male bird was continually singing, being heard even in the night. Not another Mockingbird was seen in that vicinity until May 7, 1913, when a male was seen, but only on that one occasion. A few other cases have been known of its breeding in the city, and for two or more years in succession at the respective localities. 


\section{Dumetella carolinensis. Catbird.}

Summer resident; common. Arrives from the 7 th to the 14th of May. Leaves in September, the 16th being the latest sure date, though one was thought to have been seen October 2, 1913.

The Catbird is common in the thickets along the streams, but does not penetrate far into the foothills and mountains. There are many in Monument Valley Park. An occasion of special abundance was June 1, 1907, when Aiken estimated that he saw 100 at the Skinner Ranch.

\section{Toxostoma rufum. Brown Thrasher.}

Summer resident; not common. Arrives about the first week in May, from the 4th to the 14th.

The Thrasher is found along the valley streams and gulches but does not go far into the mountains. It is of rather 1etiring habits and so escapes observation, but at best it is not at all common in El Paso County. Aiken noted a brood of young at Ramah, July 15, 1897.

\section{Toxostoma bendirei. Bendire's Thrasher.}

But one record for the County, and possibly for the State, a specimen taken at Austin's Bluffs, May 8, 1882, by Allen and Brewster.

\section{Salpinctes obsoletus obsoletus. Rock Wren.}

Summer resident; common. Arrives about April 16-20, but does not become abundant until several days after. Latest autumn date, September 23, 1907.

Rock Wrens are common about rocky places, and are also found in the arroyos with steep banks on the plains. They reach an altitude in the mountains of some 9,000 feet. They breed wherever found, in holes in the banks or in crevices in the rocks. The song of the Rock Wren is singularly like that 
of the Mockingbird; as might be supposed it lacks the power and volume of the larger bird's song.

\section{Catherpes mexicanus conspersus. Cañon Wren.}

Resident; not common.

The Cañon Wren is unquestionably a resident through the year in El Paso County, for it has been found in various months during the winter, and breeding in the summer.

Minot, June 8, 1880, found a nest near Manitou, which he described as follows: "The nest was in the roof of a cave, about ten feet from the ground, with an opening so narrow, vertically, that I could neither look in nor introduce my hand. Fortunately, however, the rock was so soft that I easily removed the bottom slab on which the nest rested. This, as one looks down upon it, suggests the Eastern Wood Peewee's. It is composed of twigs, stalks, and bits of leaves, surrounded by a few loose sticks, and thickly felted with, down silk, and a few feathers. The hollow is $2 \mathrm{I} / 2$ inches long, and scarcely half as deep. The eggs measured about $.70 \times .50$ of an inch, and are crystal white (rosy when fresh), sparsely speckled and spotted, chiefly about the crown, with medium dull brown."

In the summer of 1912 Lloyd Shaw found a pair nesting in the steep rocks at the Gateway of Crystal Park. One of the birds was seen July 19 carrying food to the young. The nest was located under an overhanging rock in the cliff and was inaccessible. Allen found the species in the Garden of the Gods in 1871, and he and Brewster found it there in 1882, also in North Cheyenne Cañon. Olive Thorne Miller found it in South Cheyenne Cañon, where it apparently had a nest in or near the Pillars or Hercules.

The Cañon Wren has a habit of creeping around among the rocks is such a fashion that when one gets just a mere glimpse of the creature he is just as apt to think it is a chipmunk as a bird. 
Thryomanes bewicki bairdi. Baird's Wren.

But one record from El Paso County, a specimen taken by Aiken at Colorado Springs, May 1, 1879.

Troglodytes aëdon parkmani. Western House Wren.

Summer resident; common. Arrives the first week in May, earliest date April 24, 1898. Leaves in September, the latest date being September 25, 1907.

Probably found all over the County, ranging up to timberline, and abundant wherever found, and breeding everywhere. Aiken found a nest with 7 fresh eggs in a cavity in a rock ledge near Palmer Lake, June 26, 1907. Their favorite nesting places are natural cavities in trees or old woodpeckers' holes, but they will use almost any hollow they can find.

\section{Telmatodytes palustris plesius. Western Marsh Wren.}

Summer resident; not common.

Arrives in April. A Marsh Wren seen by Aiken near Skinner's April 16, 1899, was probably of this form. One was shot not far from the same locality by Allen and Brewster April 22, 1882. The scarcity of records is due to the scarcity of suitable ground in the vicinity of Colorado Springs. That it breeds in the County is only presumptive; there are no records.

\section{Telmatodytes palustris iliacus. Prairie Marsh Wren.}

Winter resident; moderately common in suitable localities. Aiken saw several at Skinner's, and took one, January 15, 1908, which was examined by Oberholser and referred to this subspecies. Probably all winter residents are visitors from the north and should be so classed.

Certhia familiaris montanus. Rocky Mountain Creeper.

Resident in the mountains; not common.

The Brown Creeper is not at all common in El Paso 
County and it is rather unusual to run across one. It seems to be nearly confined to the mountains and foothills, but it has occasionally been seen within the city limits of Colorado Springs. When seen it is usually in company with the chickadees and nuthatches. It ranges as high as there is timber; was noted at Lake Moraine December 11, 1906.

Sitta carolinensis nelsoni. Rocky Mountain Nuthatch.

Resident in the mountains ; common.

This representative of the White-breasted Nuthatch is frequently seen in the foothills and mountains, and is also common on the Divide. In winter it drifts somewhat farther out to the bluffs, and has also been seen in Colorado Springs. A pair seen at Buttes May 12-20, 1908, by Aiken, were thought to be breeding.

\section{Sitta canadensis. Red-breasted Nuthatch.}

Resident in the mountains; not common.

This is by far the least common of our three species of nuthatch, and sometimes a year or more goes by without seeing one, and again it may be seen rather frequently. It seems to be mainly a mountain bird, but Aiken noted it at Fountain June 5, 1907, and May 7, 1905; he also saw it at St. Peter's Dome July 4, 1907.

\section{Sitta pygmæa. Pygmy Nuthatch.}

Resident ; common.

This little fellow is the most abundant of our nuthatches, seen in flocks when the others are seen singly. Like the others it is essentially a mountain bird, but in the winter wanders somewhat away from the foothills. It is found on the Divide and noted at Palmer Lake and Eastonville; also seen at Austin's Bluffs in winter. It frequents evergreen trees almost exclusively and is but rarely found in other kinds, and then 
the evergreen are usually not far away. While it is often found associated with Chickadees and the other nuthatches occasionally good-sized flocks which seem to consist solely of this species are seen.

\section{Bæolophus inornatus griseus. Gray Titmouse.}

Found only in the cedar and piñon region in the extreme southwestern portion of the County, where it is resident, and was found by Aiken to be common in winter but scarce in summer. It was less common in December and January thai in November and February, in which months they were most common. In winter they wander about in small flocks but in spring separate into pairs.

Penthestes atricapillus septentrionalis. Long-tailed Chickadee.

Resident; common.

This western subspecies of the common Chickadee of the East is found practically everywhere there are trees, except that possibly it does not range as high in the mountains as the Mountain Chickadee, though it has been seen at the Bison Reservoir, Teller County, 10,400 feet, but possibly an abundant food supply about a house might have had something to do with its presence there. It frequents willows and other deciduous trees. It nests in the valleys as well as in the hills and Aiken's notes contain the following description of a nest he found on the Fountain below Colorado Springs, May 6, 1899: "I saw one of the birds fly and disappear near a stump with something in its mouth. At first I discovered no hole but soon noticed a small one at the edge just inside the bark. Breaking away part of the bark I found a considerable excavation, about 10 inches deep, with the bird sitting closely at the bottom. A twig that I reached down to her she seized in her beak and allowed herself to be lifted by it nearly to the top. I was obliged to break away more bark to reach the 
bird, took her in hand and then liberated her. The nest was but half finished, only a mass of inner bark strips, So I plastered the pieces of bark in place and left it."

While each of our species of chickadees is found in flocks associated with the nuthatches and an occasional creeper, yet they seem to prefer not to have much to do with each other and are not very often found in the same flock, though they do sometimes thus associate. At the Bison Reservoir above mentioned both species came about the house for the scraps thrown out.

\section{Penthestes gambeli. Mountain Chickadee.}

Resident in the mountains; common.

This species, easily distinguished from the preceding by the white stripe on the side of the head, seems equally common with it, but is confined to the mountains in the breeding season, though wandering just as much in winter. It has been known to nest at least as high as the Strickler Tunnel, 11,500 feet. Warren saw this species at Lake Moraine in January, March, September, and December, but did not see the other species at that place on any of his visits. Keyser saw a pair feeding young in the nest near the Half Way House. It prefers to frequent spruces and other coniferous trees.

\section{Psaltriparus plumbeus. Lead-colored Bush-Tit.}

Resident; locally common.

Like the Gray Titmouse this species is found about the piñons and cedars, which constitute its breeding range, but unlike the other it wanders away from those trees at times and is occasionally found along the lower edge of the foothills, and has been known on at least one occasion to come about houses at the edge of Monument Valley Park. Warren found a flock of 40 or 50 in the northern part of the Garden of the Gods in January, 1910. Aiken took a nest with five 
eggs at Red Creek Cañon, May 10, 1876. C. N. Holden took young birds on Turkey Creek about July 12, 1872.

Regulus satrapa olivaceus. Western Golden-crowned Kinglet.

Winter resident; not common.

This species is found mainly in the mountains and foothills, and at the bluffs. We have no records of it along the valley streams. It ranges high in the mountains, Warren finding it at Lake Moraine in January, and Aiken found a small flock at Clyde, Teller County, January 12, 1908. It is sometimes found in flocks consisting of the one species, but is more often in company with chickadees and nuthatches.

Regulus calendula calendula. Ruby-crowned Kinglet.

Summer resident in the mountains; not uncommon. A spring and autumn migrant in the valley and on the plains, arriving early in April, and not all leaving until November.

This Kinglet breeds in the mountains from about 9,000 feet up, having been seen by various observers in the summer season, though no one has yet taken its nest in this region. The bird has something of a reputation as a songster, and the volume of the song is remarkable when the small size of the singer is considered. Aiken made the following note on its song at Divide, Teller County: "A Ruby-crowned Kinglet was singing vigorously from a large spruce tree. The song as I took it down after carefully listening is $T u-u-u-u-u-u$ Widdie Widdie Widdie Widdie Widdie Widdie Widdie. The whole uttered rapidly and in monotonous key except the last 'Widdie' which had rising inflection."

Polioptila cærulea obscura. Western Gnatcatcher.

Rare; but few records for the County. "Seen May 6, and killed May 7, 1872, on Turkey Creek. Rather common for a 
few days." Aiken, in note book. One take by Aiken north of Roswell, May 22, 1904, is the only record for El Paso County besides the preceding. It has never been seen in the breeding season in the County though the nest was taken by Nash at Pueblo.

Myadestes townsendi. Townsend's Solitaire.

Resident; common.

The Solitaire is a breeder in the mountains at the higher altitudes, coming lower in winter and spreading all over the region. A solitary bird in summer, but sometimes they congregate in flocks of 20 or more in warm, sheltered cañons and gulches in winter. Early in 1911 Solitaires were seen in the residence portion of Colorado Springs several times, which is something unusual.

Solitaires descend from the mountains about September first, and soon become quite plentiful in the foothills. As the season advances they seek the warmer sheltered nooks and remain there through the winter, often in small scattered flocks. Aiken first found them in Barnes's Cañon, November 1, 1871, frequenting the cedars and piñons of the hillside. Their flight and habit of alighting on the topmost twigs likened them to bluebirds. They were feeding mostly on cedar berries, but on bright warm days were often noticed on the ground beneath a bush or tree in search of insect food. At this season they seemed in full song and their notes were varied and melodious and akin to such famous songsters as the Wood Thrush, Meadowlark and Oriole. Later they were less musical and late in April when they had separated in pairs singing had ceased. At about this date, unless detained by storms, they ascend the mountains where parent birds with flying young were seen late in July. 


\section{Hylocichla fuscescens salicicola. Willow Thrush.}

Migrant; not common. Arrives May 15. We have no. autumn records.

This is the least common of our thrushes with the exception of the Alaska Hermit Thrush. Henshaw, Allen and Keyser report it from the lower mountains, 8,000-8,500 feet.

\section{Hylocichla ustulata swainsoni. Olive-backed Thrush.}

Migrant; common. Arrives May 9-15, and is abundart the rest of the month.

At Calhan and Ramah, June 4-7, 1898, Aiken found this species very numerous, estimating that over 100 individuals were seen.

Hylocichla guttata guttata. Alaska Hermit Thrush.

Migrant; not common. Usually arrives the first week in May, earliest date April 20, 1907, at Red Rock Cañon.

Migrates through the lower foothills and on the plains; found by Aiken along Fountain Creek from the town of Fountain north, in the vicinity of Colorado City, and also taken at Limon, Lincoln County. This is a bird of somewhat different habits from our other thrushes, keeping more on the ground, and in its flights not rising so high in the air; also much less shy and more approachable.

Hylocichla guttata auduboni. Audubon's Hermit Thrush.

Summer resident in the mountains; common. Arrives early in May, earliest date April 13, 1882, Allen and Brewster. A common migrant along the foothills and on the plains.

This species breeds in the mountains from 8,500 feet up, for Shaw found it in Crystal Park at that altitude in summer and notes that their songs were very common in the evening. Keyser found a nest with 4 eggs near Lake Moraine, in the lower limbs of a spruce. Aiken's notes contain a reference 
to a nest found on Mount Manitou, July 6, 1872, containing 4 young; this was in a tree $2 \mathrm{I} / 2$ feet from the ground. Warren observed it at Lake Moraine, September 2, 1905. Aiken noted it July 9 and 10, 1899, as common about Strickler Tunnel and at intervals down to the Half-Way House. His notes say: "Song not as musical close to as at a little distance. I am reminded by the song of a musician, idly striking chords on a harp and listening after each chord for the echoes to die away."

\section{Planesticus migratorius propinquus. Western Robin.}

Summer resident; common. A few frequently spend the winter. The first spring arrivals sometimes come as early as February 25, but they do not become common until some time in March, usually the first or second week. The majority leave in October.

As stated above a few Robins frequently winter with us. The winter of 1904-5 there seemed to be a good many about Colorado Springs, and they were often noted in the town from November through the winter months and until the spring migrants came to swell their numbers. One was seen January 20,1905, in a sheltered gulch in the foothills at about 7,000 feet. They do not seem to be afraid of the cold for they have been seen in zero weather. Aiken saw Robins at the Strickler Tunnel, 11,500 feet, April 22-23, 1899, and was told they had just arrived.

This species is found all over the County, and as just stated, ranges high into the mountains, and breeds wherever found. About Colorado Springs they pair in April and build immediately. Monument Valley Park had many nests in 1913, 10 being discovered in a small area; some of the young had left the nest by June 1. A young bird which was banded in a nest May 27, 1913, flew through glass in a greenhouse of the Pikes Peak Floral Co., June 23, 1913, and was killed. 
Sialia sialis sialis. Bluebird.

Rare; but one record for the County, and this was for many years the only record for Colorado. July 15,1872 , when C. N. Holden, Jr., was visiting Aiken at the Turkey Creek ranch, he took one specimen, an adult male.

Sialia mexicana bairdi. Chestnut-backed Bluebird.

Summer resident; common. Arrives the middle of March, le:aves in October.

While this species is common almost everywhere in migration, though probably never ranging quite as high as the next species, it breeds mainly in the yellow pine region between 7,000 and 8,000 feet, where it outnumbers the Mountain Bluebird. July 17, 1899, on the Divide north of Peyton, Aiken saw 20 Chestnut-backed to 5 of the Mountain Bluebirds, and it is probably more numerous on the Divide than anywhere else in the County. The two species are sometimes found in mixed flocks in the spring, especially when the weather is stormy. The appearance on the plains of this Bluebird during the spring, migration is but for a short time, as it goes into the mountains and onto the Divide by the first of April, but the storms which usually come early in May drive the birds down in small flocks which remain until the weather clears and the snow melts. At these times the birds often become much emaciated and some die from starvation, being unable to obtain food while the snow is on the ground.

Aiken found a nest on Turkey Creek, May 27, 1872, in a woodpecker's hole, with young half fledged.

Sialia currucoides. Mountain Bluebird.

Summer resident; common. Arrives from the first to the middle of March. The majority leave in October.

There are various December and January records, as well as February. It had just arrived at the Strickler Tunnel April 
$22-23,1899$. It is very generally distributed, breeding whereever found, on the plains as well as in the mountains to timberline. It often uses deserted woodpeckers' holes for nesting sites. Aiken found a nest with young in a woodpecker's hole en Turkey Creek, May 29, 1872. His notebook says it was seen occasionally (near ranch on Turkey Creek) throughout the winter of $1872-3$, and that it was very common in January, 1873.

In the early days of Colorado Springs this Bluebird bred readily in houses put up for it, but nowadays it has no show against the omnipresent English Sparrow. Like the preceding species this Bluebird congregates in flocks at the time of the May storms.

\section{ADDENDA}

H. C. Oberholser in "A Monograph of the Genus Chordeiles Swainson, Type of a New Family of Goatsuckers," U. S. National Bulletin No. 86, 1914, has described a new subspecies of Nighthawk, Chordeiles virginianus howelli, and refers the Colorado bird to it. If the form proves to be a valid one our El Paso County Nighthawks should be known by that name.

Regarding two other species Mr. Oberholser has given us the following notes:

He informs us that he now considers all the Horned Larks breeding in Colorado, and most of the winter birds, to be Otocoris alpestris enthymia, the Saskatchewan Horned Lark, a race not as yet admitted to the A. O. U. Check-List.

$\mathrm{He}$ also finds that the Savannah Sparrows of Colorado are not Passerculus sandwichensis alaudinus, but $P$. a. nevadensis Grinnell, the Nevada Savannah Sparrow. 



\section{$\begin{array}{lllll}\text { I } & \mathrm{N} & \mathrm{D} & \mathrm{E} & \mathrm{X}\end{array}$}

Acanthis linaria linaria, 556.

Accipiter cooperi, 499.

Accipiter velox, 498.

Actitis macularius, 489.

Aëronautes melanoleucus, 521 .

Agelaius phœeniceus fortis, 542 .

Aluco pratincola, 506.

Ammodramus bairdi, 563 .

Ammodramus savannarum bimaculatus, 564 .

Anas platyrhynchos, 478 .

Anthus rubescens, 588.

Aphelocoma woodhousei, 535.

Aquila chrysaëtos, 503.

Archibuteo ferrugineus, 502.

Arckibuteo lagopus sancti-johannis, 502.

Bæolophus inornatus griseus, 596 .

Baldpate, 479.

Bartramia longicauda, 488.

Bittern, 482.

Bittern, Least, 482.

Blackbird, Brewer's, 545.

Blackbird, Rusty, 545.

Blackbird, Yellow-headed, 542.

Blue-bill, Little, 480.

Bluebird, 602.

Bluebird, Chestnut-backed, 602.

Bluebird, Mountain, 602.

Bombycilla cedrorum, 579 .

Bombycilla garrula, 579.

Bobolink, 541.

Bob-white, 491.

Calamospiza melanocorys, 576 .

Calcarius lapponicus alascensis, 561.

Calcarius ornatus, 561.

Callipepla squamata, 492.

Camp Bird, 536.

Camp Robber, 536.
Archilochus alexandri, 522.

Ardea herodias herodias, 482.

Asio flammeus, 506.

Asio wilsonianus, 506 .

Astragalinus psaltria arizonæ, 557.

Astragalinus psaltria mexicanus, 557.

Astragalinus psaltria psaltria, 557.

Astragalinus tristis pallidus, 557.

Astragalinus tristis tristis, 557.

Astur atricapillus atricapillus, 499.

Asutr atricapillus striatulus, 499.

Asyndesmus lewisi, 518.

Avocet, 485.

Botaurus lentiginosus, 482.

Branta canadensis canadensis, 481.

Branta canadensis hutchinsi, 481.

Bubo virginianus pallescens, 509 .

Bubo virginianus subarcticus, 510 .

Buffle-head, 480.

Bull Bat, 520.

Bunting, Indigo, 575 .

Bunting, Lark, 576.

Bunting, Lazuli, 575.

Bunting, Snow, 561.

Bush-Tit, Lead-colored, 597.

Buteo borealis calurus, 499.

Buteo borealis krideri, 499.

Buteo swainsoni, 500.

Buzzard, Turkey, 497.

Canvas-back, 480.

Carpodacus cassini, 547.

Carpodacus mexicanus frontalis, 548.

Carthartes aura septentrionalis, 497. 


\section{N D E X}

Catbird, 592.

Catherpes mexicanus conspersus, 593.

Catoptrophorus semipalmatus inornatus, 488.

Centurus carolinus, 518 .

Certhia familiaris montanus, 594.

Ceryle alcyon, 515.

Chapparal Cock, 513.

Charadrius dominicus dominicus, 489.

Charitonetta albeola, 480 .

Chat, Long-tailed, 586.

Chaulelasmus streperus, 478.

Chen hyperboreus hyperboreus, 481.

Chen hyperboreus nivalis, 481.

Chickadee, Long-tailed, 596.

Chickadee, Mountain, 597.

Chondestes grammacus strigatus, 564.

Chordeiles virginianus henryi, 520 .

Cinclus mexicanus unicolor, 588 .

Circus hudsonius, 497.

Clangula clangula americana, 480 .

Coccyzus americanus americanus, 515.

Colaptes cafer collaris, 518.

Dafila acuta, 480.

Dendragapus obscurus obscurus, 494.

Dendroica æstiva æestiva, 584.

Dendroica auduboni, 584.

Dendroica coronata, 584.

Dendroica nigrescens, 585.

Dendroica striata, 585.

Dichromanassa rafescens, 483.

Dickcissel, 575.

Dipper, 588.

Eagle, Bald, 503.

Eagle, Golden, 503.

Egret, 482.

Egret, Reddish, 483.
Colinus virginianus, 491.

Columba fasciata fasciata, 496.

Colymbus nigricollis californicus, 476.

Compsothlypis americana usnex, 583.

Coot, 484.

Cormorant, Double-crested, 477.

Corvus brachyrhychos, 540 .

Corvus corax sinuatus, 537.

Corvus cryptoleucus, 537.

Cowbird, 542.

Crane, Little Brown, 483.

Crane, Sandhill, 484.

Creeper, Rocky Mountain, 594.

Crossbill, 554.

Crossbill, Mexican, 554.

Crow, 540.

Crow, Clarke's, 540.

Cryptoglat1x acadica acadica, 506.

Cuckoo, Yellow-billed, 515.

Curlew, Long-billed, 489.

Cyanocephalus cyanocephalus, 541 .

Cyanocitta cristata, 534.

Cyanocitta stelleri diademata, 534 .

Dolichonyx oryzivorus, 541.

Dove, Western Mourning, 496.

Dowitcher, Long-billed, 487.

Dryobates pubescens homorus, 516 .

Dryobates villosus monticola, 516 .

Duck, Gray, 478.

Duck, Lesser Scaup, 480.

Duck, Ring-necked, 480.

Duck, Ruddy, 480.

Dumetella carolinensis, 592.

Egret, Snowy, 483.

Egretta candidissima, 483.

Elanoides forficatus, 497.

Empidonax difficilis, 528. 


\section{N D E X}

Empidonax griseus, 530.

Empidonax hammondi, 529.

Empidonax minimus, 528.

Empidonax trailli trailli, 528.

Empidonax wrighti, 530.

Falco columbarius columbarius, 504

Falco columbarius richardsoni, 505.

Falco mexicanus, 504.

Falco peregrinus anatum, 504.

Falco sparverius sparverius, 505.

Falcon, Prairie, 504.

Finch, Cassin's Purple, 547.

Finch, House, 548.

Finch, Pine, 559.

Finch, Black Rosy, 555.

Finch, Brown-capped Rosy, 556.

Finch, Gray-crowned, 554.

Gadwall, 478.

Gallinago delicata, 486.

Gallinula galatea, 484 .

Gallinule, Florida, 484.

Gavia arctica, 476.

Gavia immer, 476.

Geococcyx californianus, 513.

Geothlypis trichas occidentalis, 586.

Glaucidium gnoma pinicola, 512.

Gnatcatcher, Western, 598.

Golden-eye, 480.

Goldfinch, 557.

Goldfinch, Arizona, 557.

Goldfinch, Arkansas, 557.

Goldfinch, Mexican, 557.

Goldfinch, Pale, 557.

Goose, Canada, 481.

Goose, Greater Snow, 481.

Goose, Hutchins's, 481.

Haliætus leucocephalus, 503 .

Hawk, Bullet, 504.

Hawk, Cooper's, 499.

Hawk, Duck, 504.
Ereunetes pusillus, 487.

Erismatura jamaicensis, 480.

Euphagus carolinus, 545.

Euphagus cyanocephalus, 545.

Finch, Hepburn's Rosy, 555.

Flicker, Red-shafted, 518.

Fulica americana, 484.

Flycatcher, Ash-throated, 526.

Flycatcher, Gray, 530.

Flycatcher, Hammond's, 529.

Flycatcher, Least, 528.

Flycatcher, Olive-sided, 527.

Flycatcher, Traill's, 528.

Flycatcher, Western, 528.

Flycatcher, Wright's, 530.

Goose, Snow, 481.

Goshawk, 499.

Goshawk, Western, 499.

Grackle, Bronzed, 546.

Grebe, Eared, 476.

Grebe, Pied-billed, 476.

Grosbeak, Black-headed, 574.

Grosbeak, Rocky Mountain Pine, 547.

Grosbeak, Western Blue, 575.

Grosbeak, Western Evening, 546.

Grouse, Columbian Sharp-tailed, 494.

Grouse, Dusky, 494.

Grus canadensis, 483.

Grus mexicana, 484.

Guiraca cærulea lazula, 575 .

Gull, Bonaparte's, 477.

Gull, Ring-billed, 477.

Hawk, Fish, 505.

Hawk, Krider's, 499.

Hawk, Marsh, 497.

Hawk, Pigeon, 504. 


\section{I $N \quad D \quad E X$}

Hawk, Richardson's Pigeon, 505.

Hawk, Rough-legged, 502.

Hawk, Sharp-shinned, 498.

Hawk, Sparrow, 505.

Hawk, Squirrel, 500.

Hawk, Swainson's, 500.

Hell Diver, 476.

Helodromas solitarius cinnamomeus, 488.

Herodias egretta, 482.

Heron, Black-crowned Night, 483.

Heron, Great Blue, 482.

Hesperiphona vespertina montana, 546.

Icteria virens longicauda, 586.

Icterus bullocki, 545 .

Ictinia mississippiensis, 497.

Ibis, White-faced Glossy, 482.

Jay, Blue, 534.

Jay, Long-crested, 534.

Jay, Piñon, 541.

Jay, Rocky Mountain, 536.

Jay, Woodhouse's, 535.

Junco aikeni, 568.

Junco hyemalis hyemalis, 568 .

Junco hyemalis connectens, 568 .

Junco mearnsi, 570.

Junco montanus, 569 .

Killdeer, 490.

Kingbird, 524.

Kingbird, Arkansas, 525.

Kingbird, Cassin's, 526.

Kingfisher, Belted, 515.

Lanius borealis, 580 .

Lanius ludovicianus excubitorides, 580.

Lanivireo solitarius cassini, 582.

Lanivireo solitarius plumbeus, 582.

Lark, Desert Horned, 530.

Larus delawarensis, 477.

Larus philadelphia, 477.
Hirundo erythrogastra, 578.

Hummingbird, Black-chinned, 522.

Hummingird, Broad-tailed, 523.

Hummingbird, Calliope, 524.

Hummingbird, Rufous, 523.

Hydrochelidon nigra surinamensis, 477.

Hylocichla fuscescens salicicola, 600.

Hylocichla guttata auduboni, 600 .

Hylocichla guttata guttata, 600 .

Hylocichla ustulata swainsoni, 600 .

Ibis, Wood, 482.

Iridoprocne bicolor, 578 .

Ixobrychus exilis, 482.

Junco oreganus shufeldti, 569.

Junco phæonotus caniceps, 570 .

Junco, Aiken's, 568.

Junco, Gray-headed, 570 .

Junco, Intermediate, 568.

Junco, Montana, 569.

Junco, Pink-sided, 570.

Junco, Shufeldt's, 569.

Junco, Slate-colored, 568.

Junco, White-winged, 568.

Kinglet, Ruby-crowned, 598.

Kinglet, Western Golden-crowned, 598.

Kite, Mississippi, 497.

Kite, Swallow-tailed, 497.

Leucosticte atrata, 555 .

Leucosticte australis, 556.

Leucosticte tephrocotis tephrocotis, 554.

Leucosticte tephrocotis littoralis, 555.

Linnet, Pine, 559.

Lobipes lobatus, 484. 


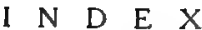

Lophodytes cucullatus, 478.

Lophortyx californica, 493.

Longspur, Alaska, 561.

Longspur, Chestnut-collared, 561.

Longspur, McCown's, 562.

Macrorhamphus griseus scolopaceus, 487.

Magpie, 532.

Mallard, 478.

Mareca americana, 479.

Marila affinis, 480.

Marila americana, 480.

Marila collaris, 480 .

Marila valisineria, 480 .

Meadowlark, Western, 543.

Melanerpes erythrocephalus, 517.

Meleagris gallopavo merriami, 495.

Melospiza georgiana, 572 .

Melospiza lincolni lincolni, 572.

Melospiza melodia juddi, 572.

Nettion carolinense, 479.

Night Hawk, Western, 520.

Nucifraga columbiana, 540 .

Numenius americanus, 489.

Nutcracker, Clarke's, 540.

Nuthatch, Pygmy, 495.

Oidemia deglandi, 480.

Olor columbianus, 481.

Oporornis tolmiei, 586.

Oreoscoptes montanus, 590.

Oreospiza chlorura, 573.

Oriole, Bullock's, 545.

Osprey, 505.

Otocoris alpestris leucolæma, 530.

Otus asio aikeni, 507.

Otus asio maxwelliæ, 506.

Otus flammeolus, 508.

Ousel, Water, 588.

Oven-bird, 586.

Owl, Aiken's Screech, 507.
Loon, 476.

Loon, Black-throated, 476.

Loxia curvirostra minor, 554 .

Loxia curvirostra stricklandi, 554.

Melospiza melodia montana, 571.

Merganser, American, 478.

Merganser, Hooded, 478.

Mergus americanus, 478.

Micropalma himantopus, 487.

Mimus polyglottos leucopterus, 591.

Mniotilta varia, 582.

Mockingbird, Mountain, 590.

Mockingbird, Western, 591.

Molotrus ater, 542.

Mud-hen, 484.

Myadestes townsendi, 599.

Mycteria americana, 482.

Myiarchus cinerascens, 526 .

Myiochanes richardsoni, 528.

Nuthatch, Red-breasted, 495.

Nuthatch, Rocky Mountain, 495.

Nuttallornis borealis, 527.

Nyctea nyctea, 510 .

Nycticorax nycticorax nævius, 483.

Owl, Arctic Horned, 510.

Owl, Barn, 506.

Owl, Burrowing, 511.

Owl, Flammulated Screech, 508.

Owl, Long-eared, 506.

Owl, Prairie Dog, 511.

Owl, Rocky Mountain Pygmy, 512.

Owl, Rocky Mountain Screech, 50J.

Owl, Saw-whet, 506.

Owl, Short-eared, 506.

Owl, Snowy, 510.

Owl, Spotted, 506.

Owl, Western Horned, 510.

Oxyechus vociferus, 490 . 


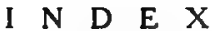

Pandion haliäetus carolinensis, 505.

Passer domesticus, 560 .

Passerculus sandwichensis alaudinus, 562.

Passerina amœna, 575.

Passerina cyanea, 575.

Pedicecetes phasianellus columbianus, 494.

Peewee, Western Wood, 528.

Pelecanus erythrorhynchos, 477.

Pelican, White, 477.

Penthestes atricapillus septentrionalis, 596.

Penthestes gambeli gambeli, 597.

Perisoreus canadensis capitalis, 536

Petrochelidon lunifrons lunifrons, 577.

Phalacrocorax auritus auritus, 477.

Phalænoptilus nuttalli nuttalli, 520 .

Phalarope, Northern, 484.

Phalarope, Wilson's, 484.

Phasianus torquatus, 495.

Pheasant, Mongolian, 495.

Pheasant, Ring-necked, 495.

Philohela minor, 486.

Phobe, Say's, 527.

Pica pica hudsonia, 532.

Picoides americanus dorsalis, 516.

Pigeon, Band-tailed, 496.

Quail, Blue, 492.

Quail, California, 493.

Quail, Mexican, 492.

Quail, Scaled, 492.

Rail, Virginia, 484.

Rallus virginianus; 484.

Raven, 537.

Raven, White-necked, 537.

Recurvirostra americana, 485.

Redhead, 480.

Redtail, Western, 499.

Redpoll, 556.

Redstart, 587.
Pinicola enucleator montana, 547.

Pintail," 480.

Pipilo fuscus mesoleucus, 573.

Pipilo maculatus arcticus, 572 .

Pipilo maculatus montanus, 573.

Pipit, 588.

Piranga erythromelas, 577.

Piranga ludoviciana, 577.

Pisobia bairdi, 487.

Pisobia fuscicollis, 487.

Pisobia minutilla, 488.

Planesticus migratorius propinquus, 601 .

Plectrophenax nivalis, 561.

Plegadis guarana, 482.

Plover, Black-bellied, 489.

Plover, Golden, 489.

Plover, Mountain, 490.

Plover, Upland, 488.

Podasocys montanus, 490.

Podilymbus podiceps, 476.

Polioptila cærulea obscura, 598.

Poœeetes gramineus confinis, 562.

Poor-will, 520.

Porzana carolina, 474.

Protonotaria citrea, 582.

Psaltriparus plumbeus, 597.

Querquedula cyanoptera, 479 .

Querquedula discors, 479.

Quiscalus quiscula æneus, 546 .

Redwing, Thick-billed, 542.

Regulus calendula calendula, 598.

Regulus satrapa olivaceus, 598.

Rhyncophanes mccowni, 562 .

Riparia riparia, 578.

Road Runner, 513.

Robin, Western, 601.

Rough-leg, Ferruginous, 502. 


\section{N D E X}

Salpinctes obsoletus obsolețs, 592.

Sand Martin, 578.

Sandpiper, Baird's, 487.

Sandpiper, Bartramian, 488.

Sandpiper, Least, 488.

Sandpiper, Semi-palmated, 487.

Sandpiper, Spotted, 488.

Sandpiper, Stilt, 487.

Sandpiper, Western Solitary, 488.

Sandpiper, White-rumped, 487.

Sapsucker, Red-naped, 517.

Sapsucker, Williamson's, 517.

Sayornis sayus, 527.

Scoter, White-winged, 480.

Seiurus aurocapillus, 586.

Selasphorus platycercus, 523.

Selasphorus rufus, 523 .

Setophaga ruticilla, 587.

Sheldrake, 478.

Shoveller, 479.

Shrike, Northern, 580.

Shrike, White-rumped, 580.

Sialia currucoides, 602.

Sialia mexicana bairdi, 602.

Sialia sialis sialis, 602 .

Siskin, Pine, 559.

Sitta canadensis, 495.

Sitta carolinensis nelsoni, 495.

Sitta pygmæa, 495.

Snipe, Jack, 486.

Snipe, Wilson's, 486.

Solitaire, Townsend's, 599.

Sora, 484.

Sparrow, Baird's, 563.

Sparrow, Brewer's, 567.

Sparrow, Clay-colored, 567.

Sparrow, Dakota Song, 572.

Sparrow, English, 560.

Sparrow, Gambel's, 565.

Sparrow, Harris's, 564.
Sparrow, House, 560.

Sparrow, Lincoln's, 572.

Sparrow, Mountain Song, 571.

Sparrow, Swamp, 572.

Sparrow, Western Chipping, 566.

Sparrow, Western Grasshopper, 564.

Sparrow, Western Lark, 564.

Sparrow, Western Savannah, 562.

Sparrow, Western Tree, 566.

Sparrow, Western Vesper, 562.

Sparrow, White-crowned, 564.

Spatula clypeata, 479.

Speotyto cunicularia hypogæa, 511.

Sphyrapicus thyroideus, 517.

Sphyrapicus varius nuchalis, 517 .

Spinus pinus, 559.

Spiza americana, 575.

Spizella breweri, 567.

Spizella monticola ochracea, 566 .

Spizella pallida, 567.

Spizella passerina arizonæ, 566.

Spoonbill, 479.

Squatarola squatarola, 489.

Steganopus tricolor, 484.

Stelgidopteryx serripennis, 579 .

Stellula calliope, 524.

Sterna forsteri, 477.

Strix occidentalis occidentalis, 506.

Sturnella neglecta, 543.

Swallow, Bank, 578.

Swallow, Barn, 578.

Swallow, Cliff, 577.

Swallow, Eave, 577.

Swallow, Rough-winged, 579.

Swallow, Tree, 578.

Swallow, Violet-green, 578.

Swan, Whistling, 481.

Swift, 504.

Swift, White-throated, 521.

Tanager, Scarlet, 577.

Tanager, Western, 577.
Tachycineta thalassina lepida, 578.

Tanager, Louisiana, 577. 


\section{I $N \quad D \quad E \quad X$}

Teal, Blue-winged, 479.

Teal, Cinnamon, 479.

Teal, Green-winged, 479.

Telmatodytes palustris iliacus, 594.

Telmatodytes palustris plesius, 594 .

Thrush, Alaska Hermit, 600.

Thrush, Audubon's Hermit, 600.

Thrush, Olive-backed, 600.

Thrush, Willow, 600.

Thryomanes bewicki bairdi, 594 .

Titmouse, Gray, 596.

Totanus flavipes, 488.

Totanus melanoleucus, 488.

Towhee, Arctic, 572.

Towhee, Cañon, 573.

Vermivora celata celata, 583.

Vermivora peregrina, 583.

Vermivora virginiæ, 582 .

Vireo, Cassin's, 582.

Vireo, Plumbeous, 582.

Warbler, Audubon's, 584.

Warbler, Black and White, 582.

Warbler, Black-poll, 585.

Warbler, Black-throated Gray, 585

Warbler, MacGillivray's, 586.

Warbler, Myrtle, 584.

Warbler, Northern Parula, 583.

Warbler, Orange-crowned, 583.

Warbler, Pileolated, 587.

Warbler, Prothonotary, 582.

Warbler, Tennessee, 583.

Warbler, Virginia's, 582.

Warbler, Yellow, 584.

Waxwing, Bohemian, 579.

Waxwing, Cedar, 579.

Widgeon, 479.

Wild Carrary, 557.

Willet, Western, 488.
Tern, Black, 477.

Tern, Forster's, 477.

Thrasher, Bendire's, 592.

Thrasher, Brown, 592.

Thrasher, Sage, 590.

Towhee, Green-tailed, 573.

Towhee, Mountain, 573.

Toxostoma bendirei, 592.

Toxostoma rufum, 592.

Troglodytes aedon parkmani, 594.

Turkey, Merriam's, 495.

Turkey, Wild, 495.

Tyrannus tyrannus, 524.

Tyrannus verticalis, 525 .

Tyrannus vociferans, 526 .

Vireo, Swainson's, 581.

Vireo, Western Warbling, 581.

Vireosylva gilva swainsoni, 581 .

Vulture, Turkey, 497.

Wilsonia pusilla pileolata, 587

Woodcock, 486.

Woodpecker, Alpine Three-toed, 517.

Woodpecker, Batchelder's, 516.

Woodpecker, Downy, 516.

Woodpecker, Hairy, 516.

Woodpecker, Lewis's, 518.

Woodpecker, Red-bellied, 518.

Woodpecker, Red-headed, 517.

Woodpecker, Rocky Mountain

Hairy, 516.

Wren, Baird's, 594.

Wren, Cañon, 593.

Wren, Prairie Marsh, 594.

Wren, Rock, 592.

Wren, Western House, 594.

Wren, Western Marsh, 594. 


\section{I $N$ D $E$ E X}

Xanthocephalus xanthocephalts, Zamelodia melanocephala, 574.

542.

Yellow-legs, 488.

Zenaidura macroura marginella, 496.

Zonotrichia leucophrys leucophrys, 564.

Yellow-legs, Greater, 488.

Zonotrichia leucophrys gambeli, 565

Yellow-throat, Western, 586.

Zonotrichia querula, 564. 






